\title{
أثر العناصر الزخرفية للوشم والحناء في القرن التاسع عشر على الأزياء (المشتسملة) في شهال أفريقيا
}

\author{
إعلاد \\ أ.م. ده/هبة أحمد يس \\ الأستاذ المساعد بقسم الملابس والنسيج \\ كلية الاقتصاد المنزلى - جامعة حلوان
}

مجلة بحوث التربية النوعية ـ جامعة المنصورة

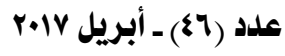




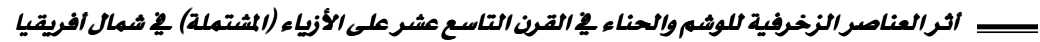




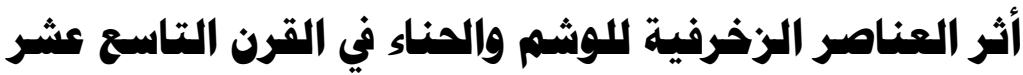

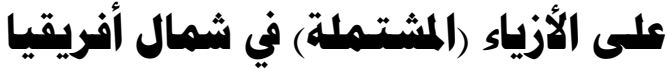

\author{
إعداد

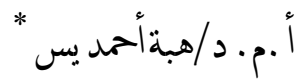

unill

يهـدف البحث إلى دراسة لبعض النماذج التاريخية لزخارف الحناء والوشم هِّ شمال إفريقيا

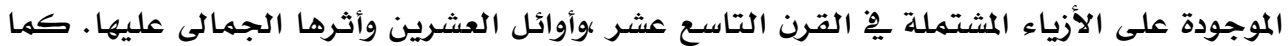

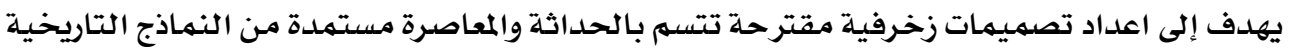

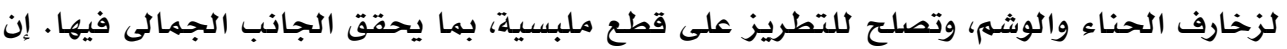

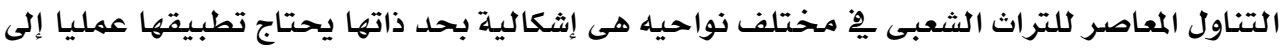

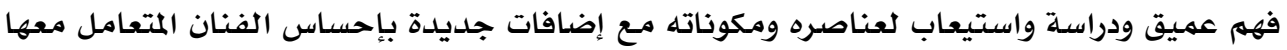

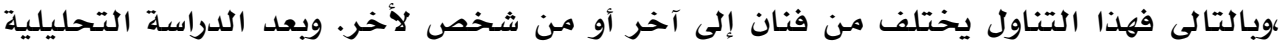

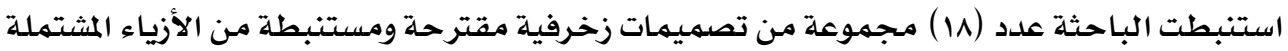

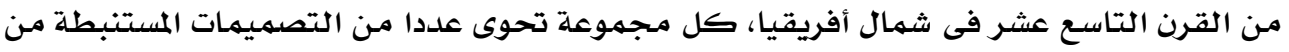

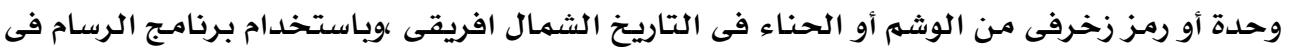

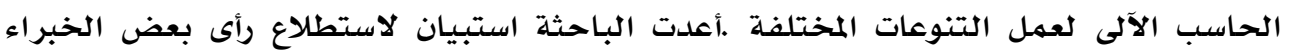

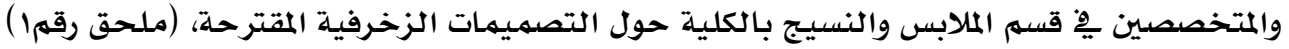

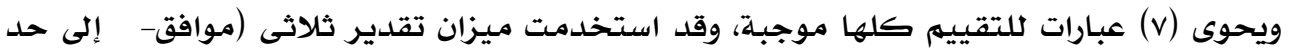

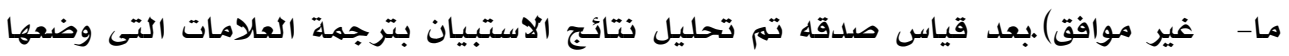

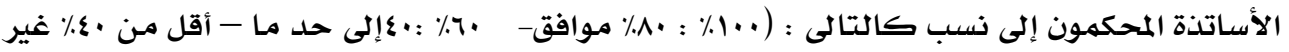

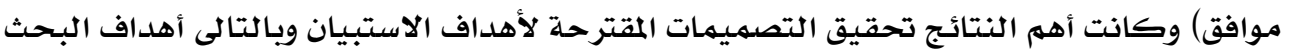

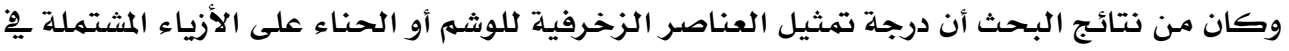

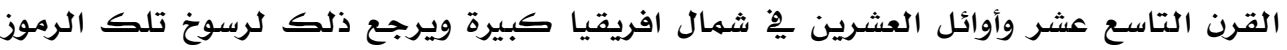

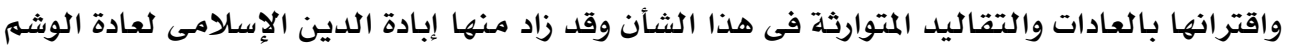

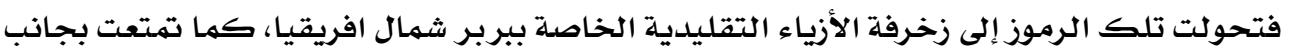

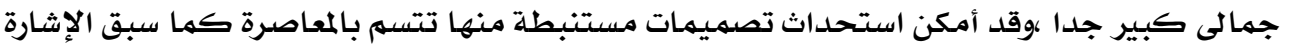

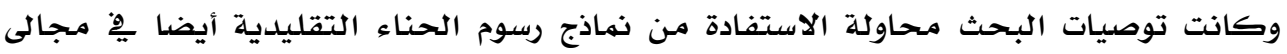

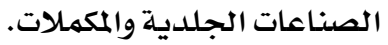

" الأستاذ المساعد بقسم الملابس والنسيج - كلية الإقتصاد المنزبي - جامعة حلوان 


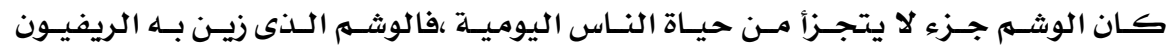

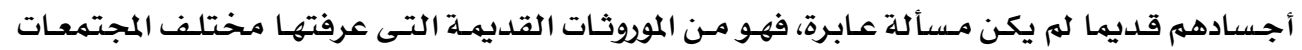

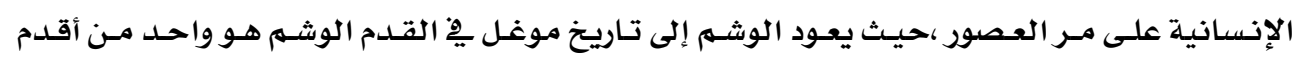

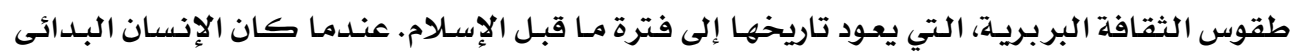

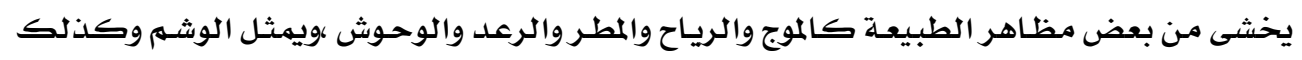

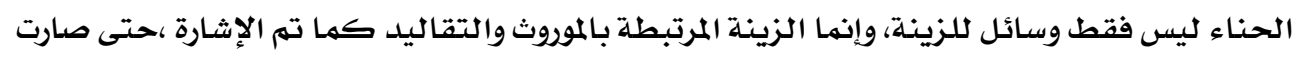

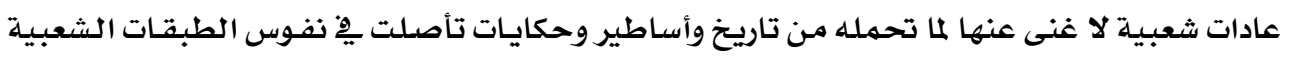

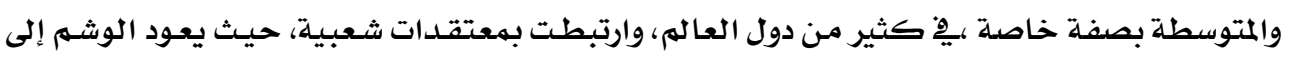

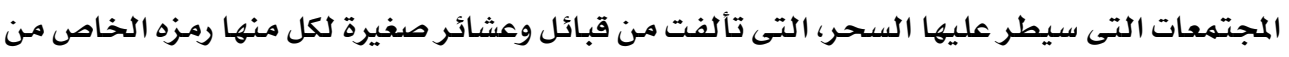

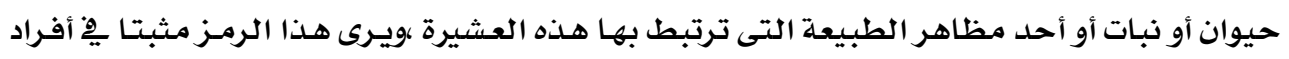

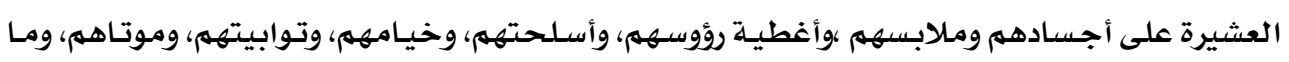

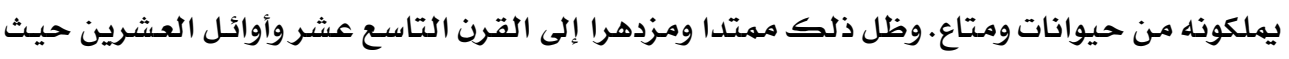

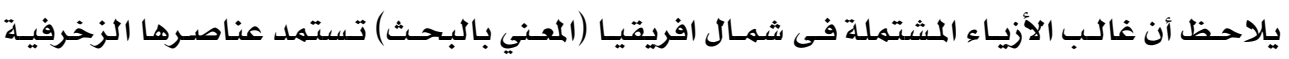

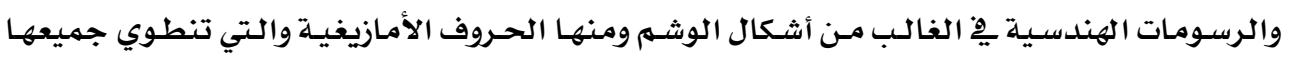

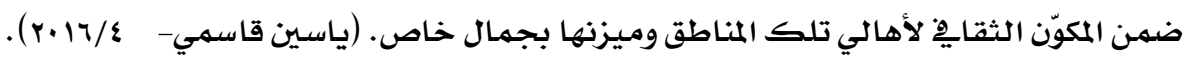

\section{هشكلة البحث:}

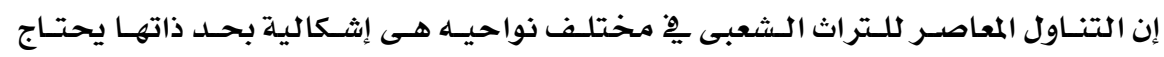

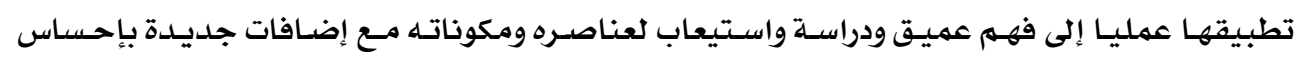

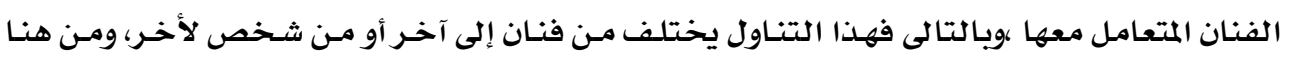

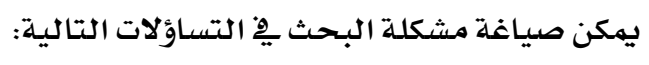

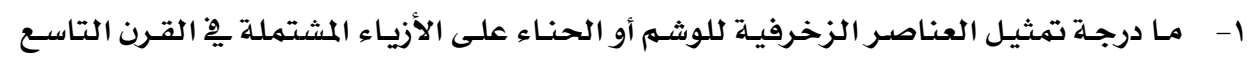

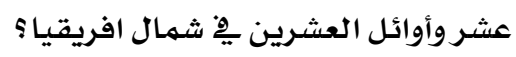

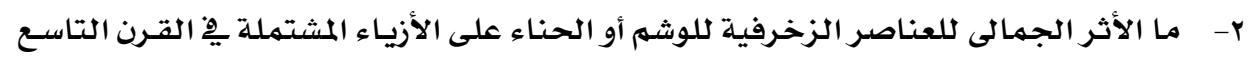

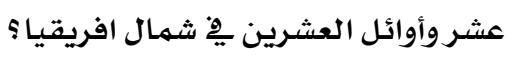

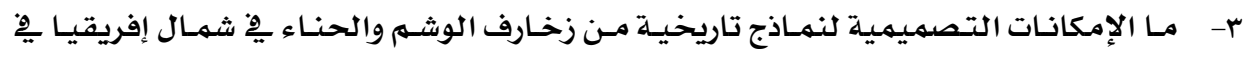

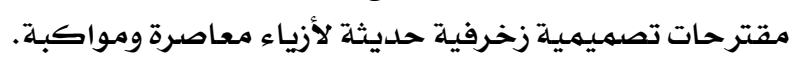

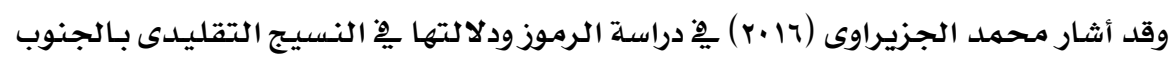

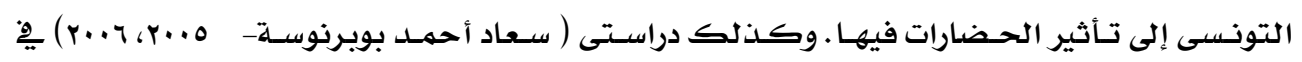

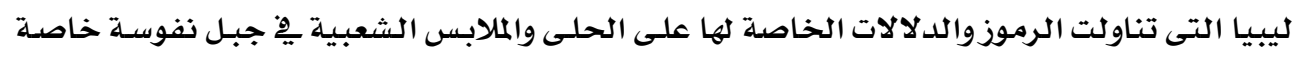

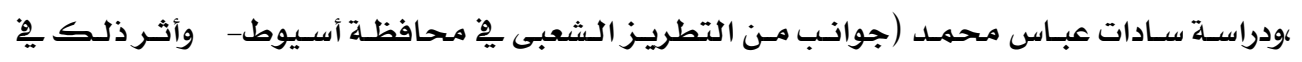




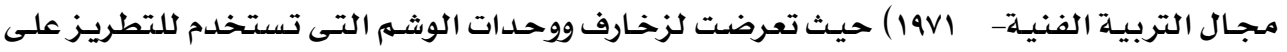

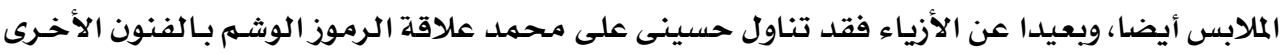

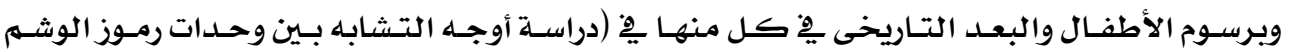

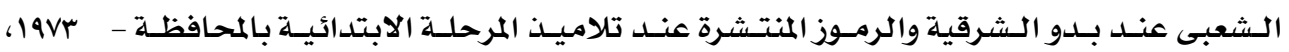

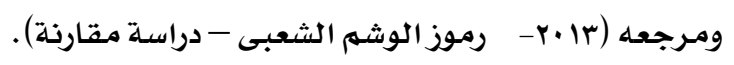

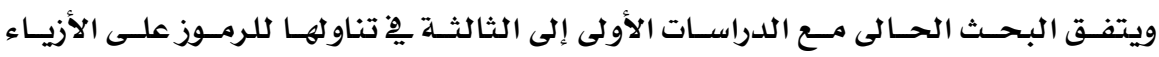

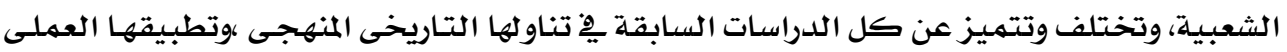

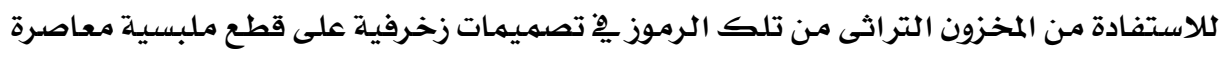

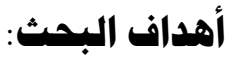

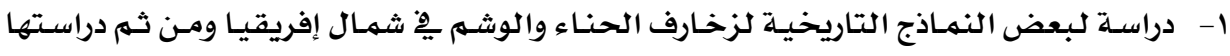

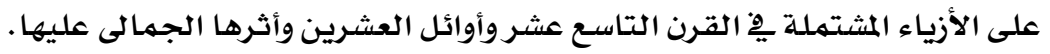

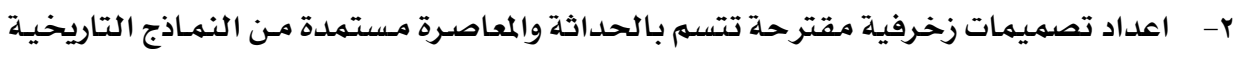

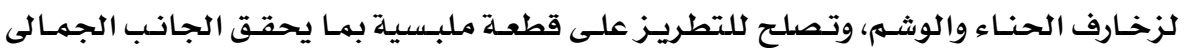

$$
\text { فيها. }
$$

\section{أهميهة البحث:}

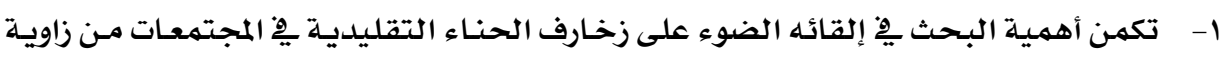

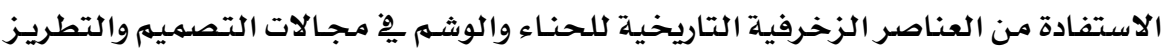

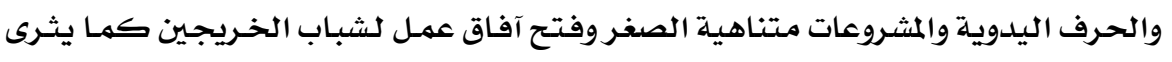

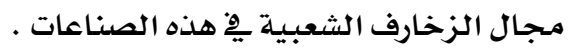

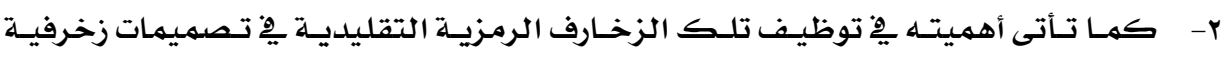

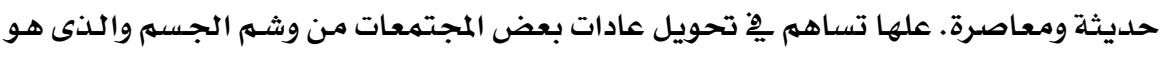

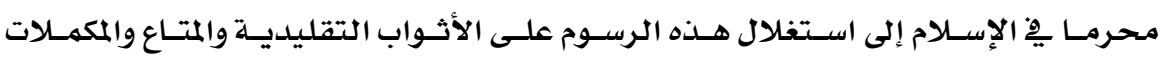

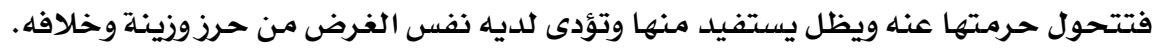

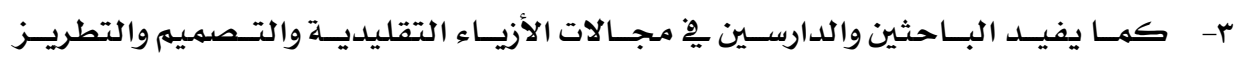

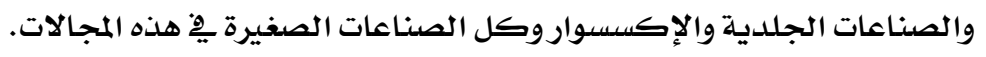

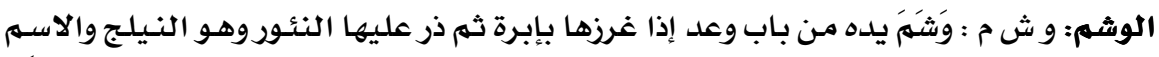

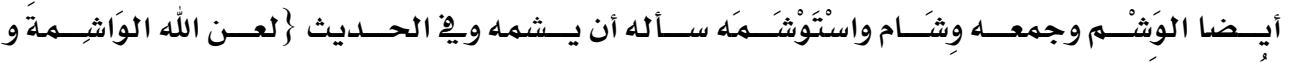

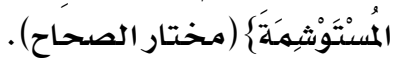


الوشم فن له دلالات عقائدية وفلسفية واجتماعيـة ، يرسهم بواسطة الإبر والمساحيق فيبقى

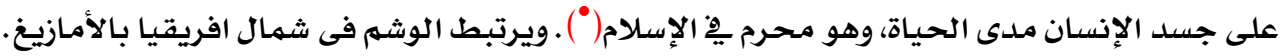

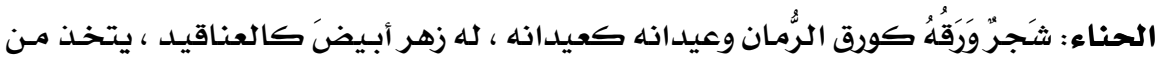

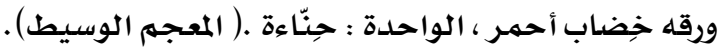

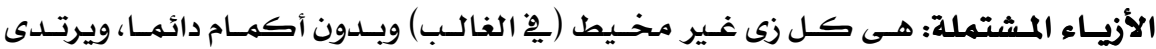
بالالتحاف كالبطاطين والشيلان والبر انس وأغطية الرأس من الطرئ من الطرح. الأمـازيغ أو البربر هم من الشعوب الأصلية التي تسكن المنطقة الممتدة من واحسة سيوة شـرقا

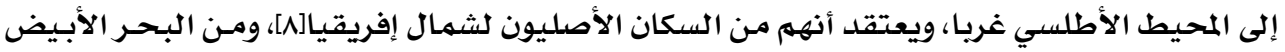
المتوسط شمالا إلى الصحراء الكبرى جنوبا، وهي المنطقة التي كان يطلق عليها الإغريق قديما باسيهم

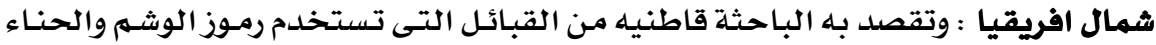

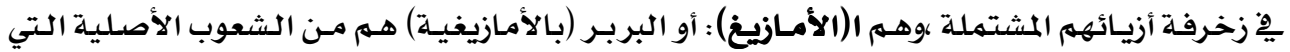

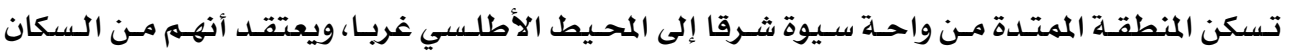

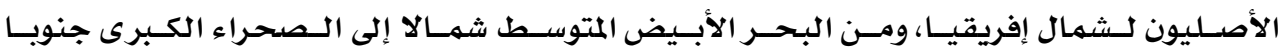
(www.wikipidia.com)

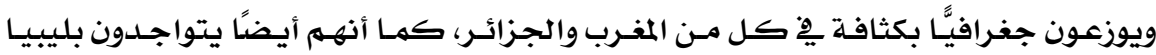

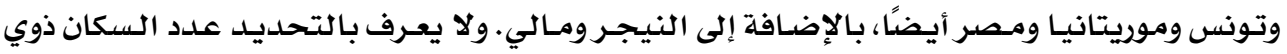

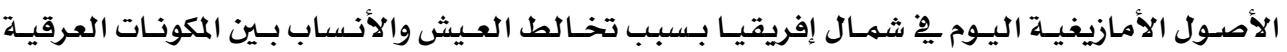

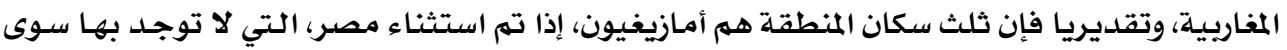

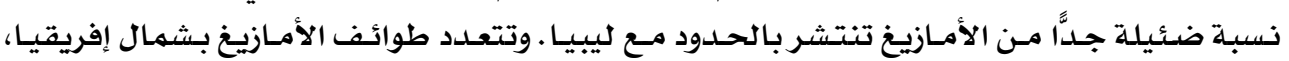

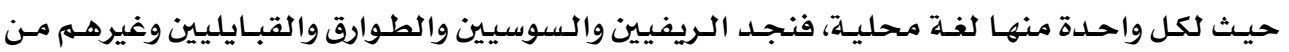

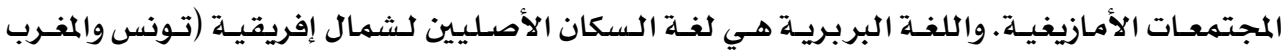

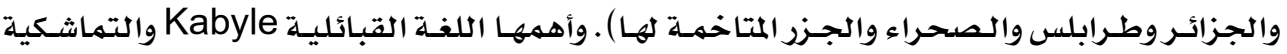
Temachek .(http://www.nouhworld.com/article.html)

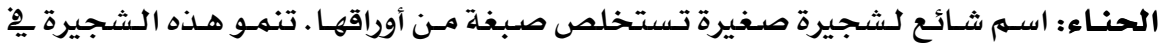

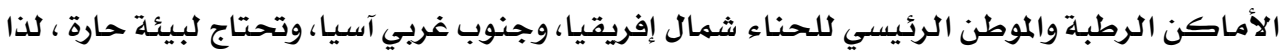

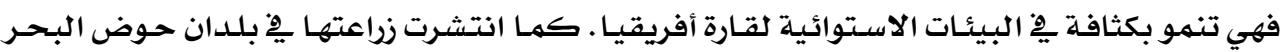

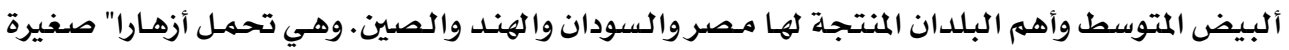

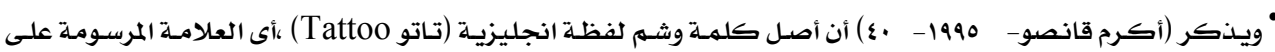

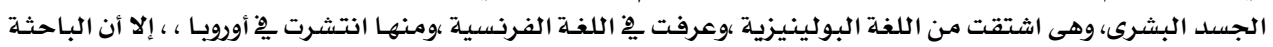

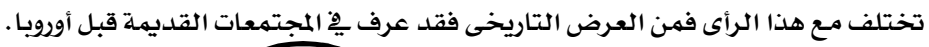


بيضاء أو وردية اللون لها شذىى وتتجمـع على شكل عنقود. إن الصبغة ذات اللون البرتقالي المنتجـة مـن

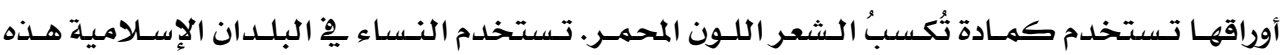

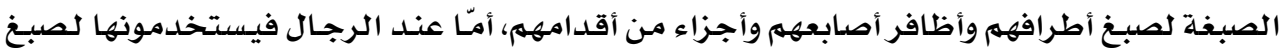

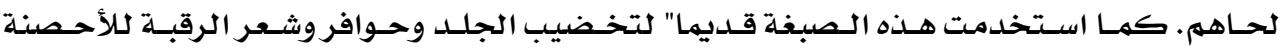

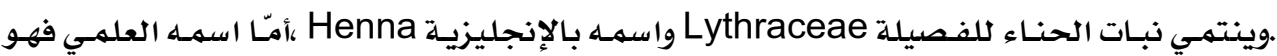
الجناء

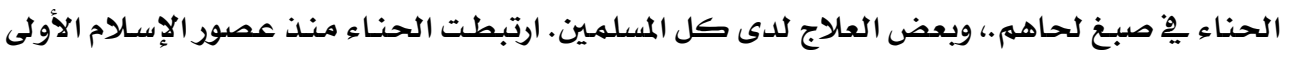

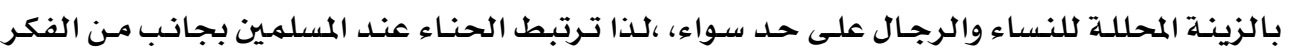

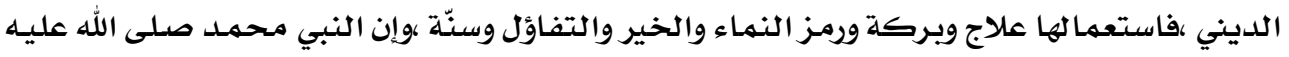

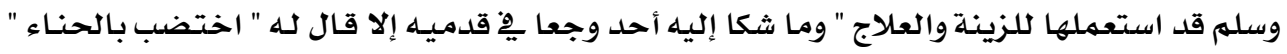

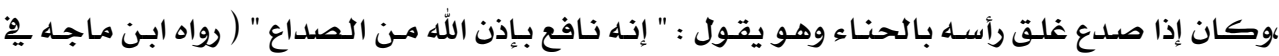

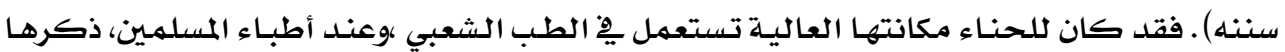

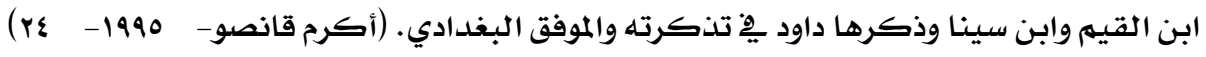

\section{هدود البحث:}

\section{- م الحدود المكانية : شمال إفريقيا.

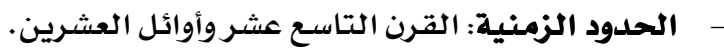

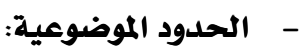

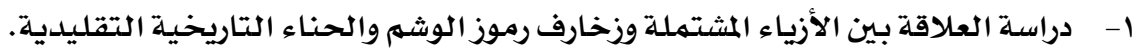

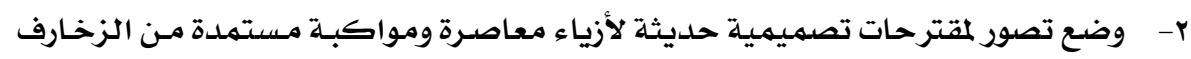

التاريخية من الوشم والحناء ِِّ شمال إفريقيا.

\section{هنهمج البمث:}

يتبع البحث المنهج الوصفي لوصف وتحليل علاقة الأزياء المثتملة يِّ القرن التاسـع عشر

$$
\text { وأوائل العشرين بالوشهم والحناء. }
$$

أدوات البحث:

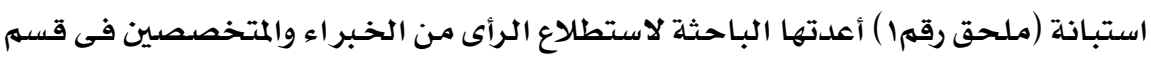

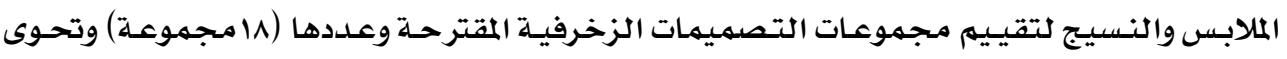

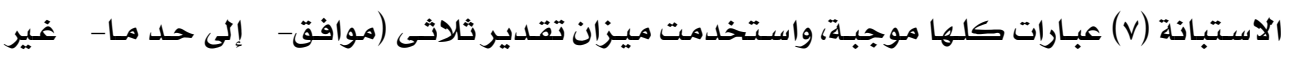
موافق).

صـدق الاسـتبيان: لقيـاس صسدق الاسـتبيان مـن حيـث اللغسة والـصسياغة وملاءمسة عبـارات

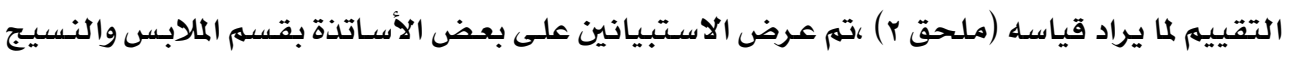


كلية الاقتصاد المنزلى - ج حلـوان (ملحق r) ،وقد تم حـذف إحـدى العبـارات واستبدا لها بـأخرى ،بنـاء

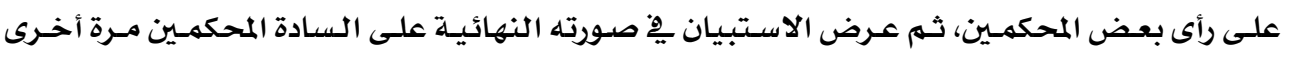

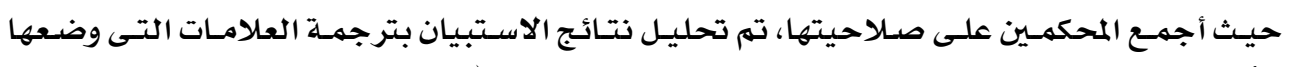

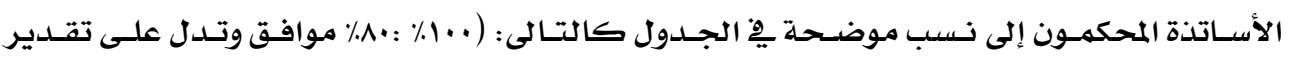

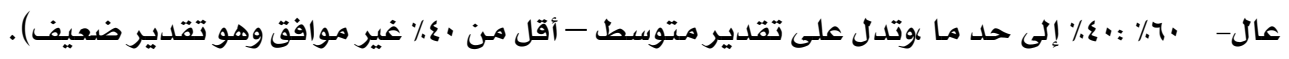

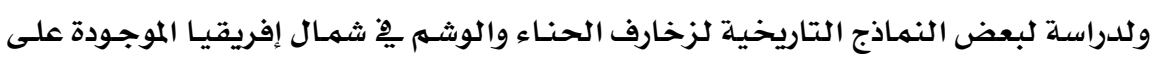

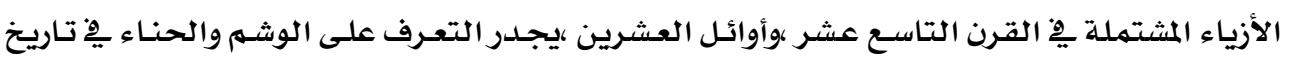

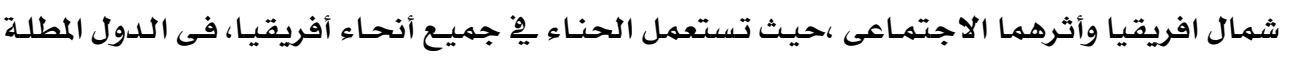

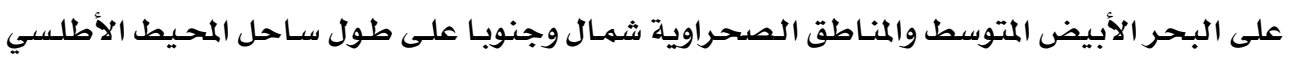

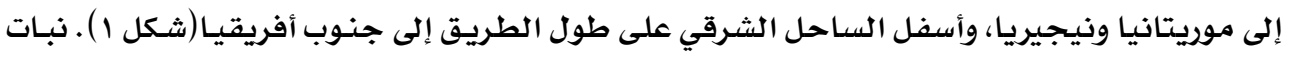

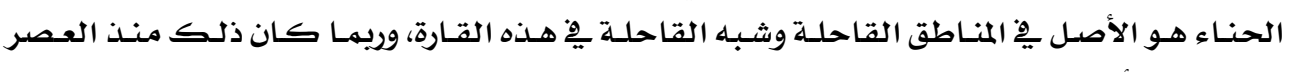

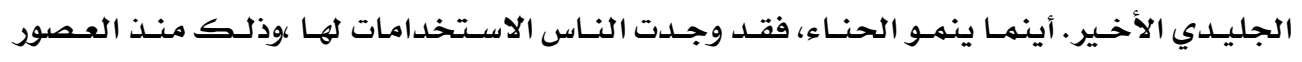

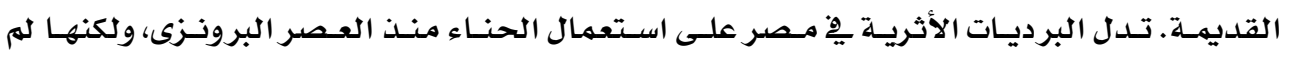

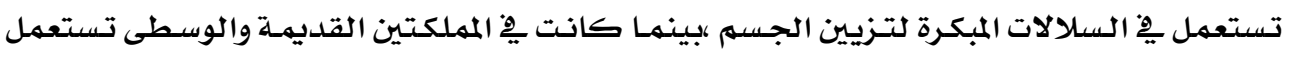

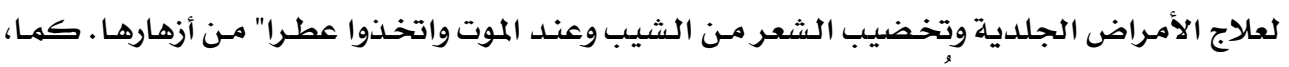

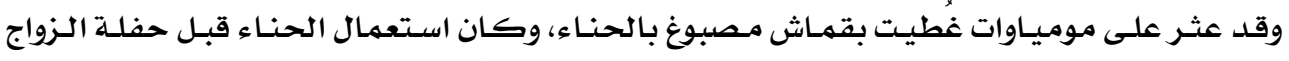

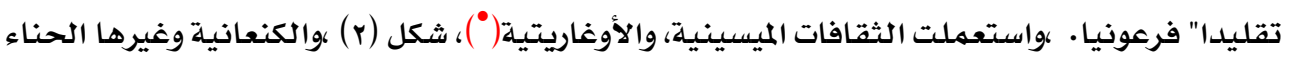

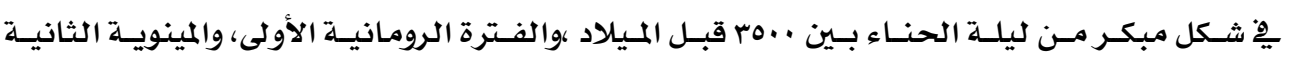

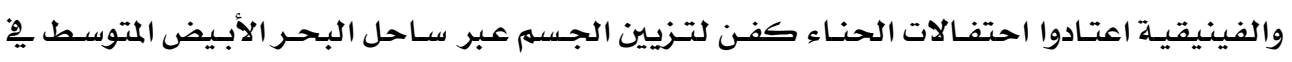

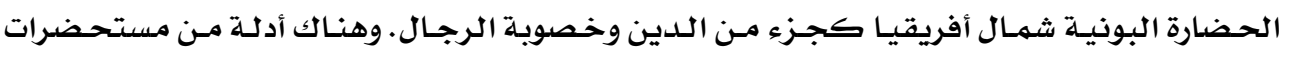

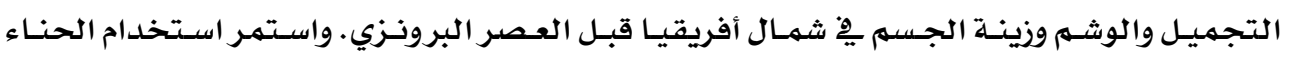

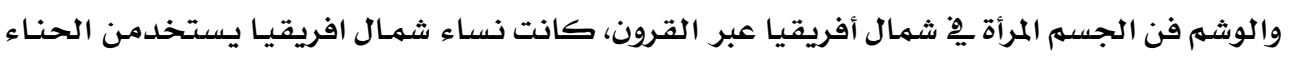

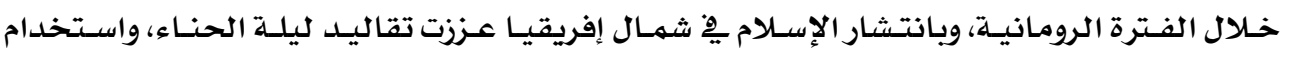

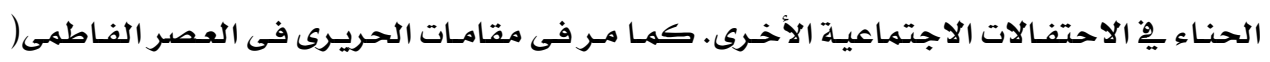
(5: 8 -2008 _Catherine Cartwright-Jones

• الميسينية أو المينوية تعتبر من أقدم حضارات اليونان وأوروبا عموما ،وتعود إلى العصر البرونزي. موطن الحضارة يقع ِيِ

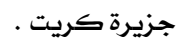

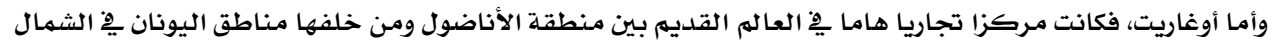

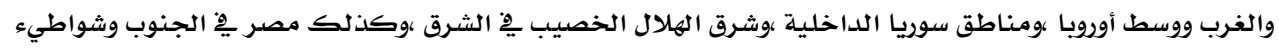

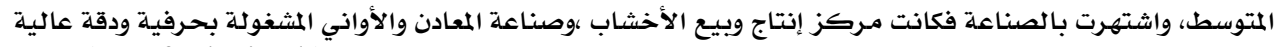

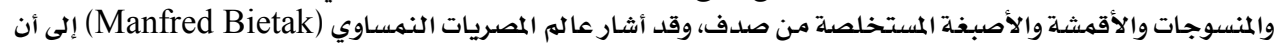

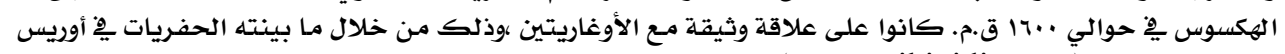
عاصمة الهكسوس (www.wikipidia.com). 


\begin{tabular}{|c|}
\hline 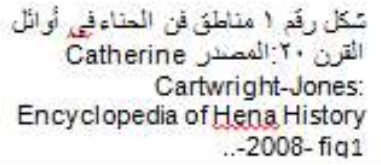 \\
\hline 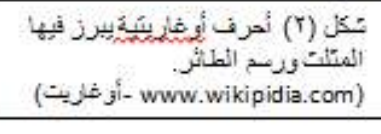 \\
\hline
\end{tabular}

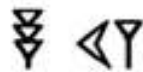

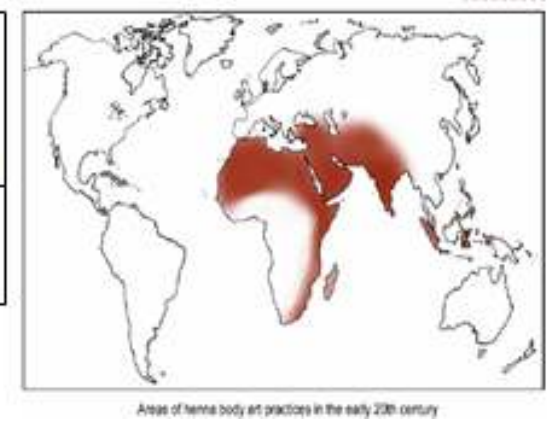

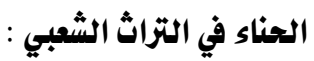

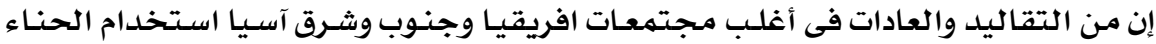

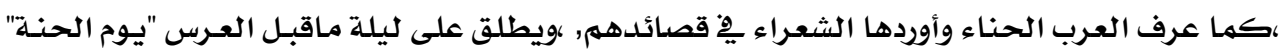

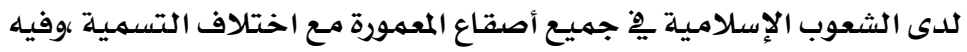

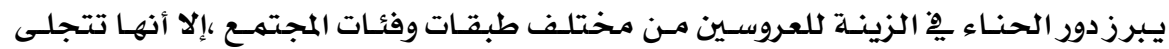

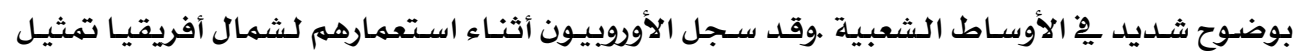

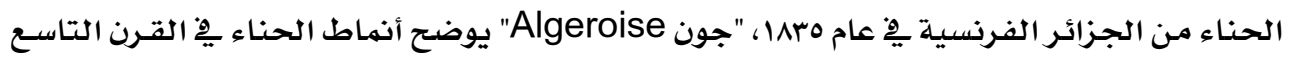

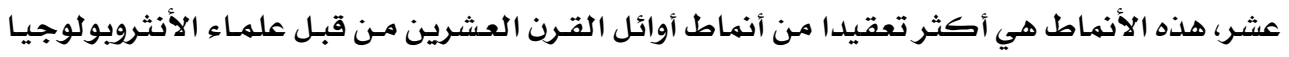

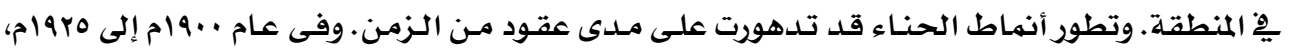

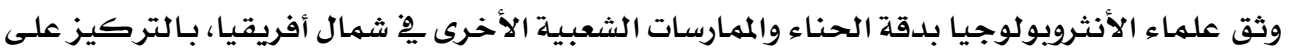

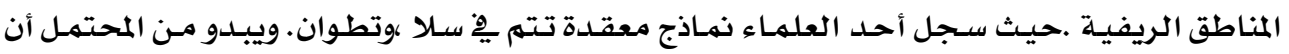

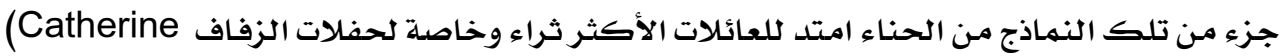
Cartwright-Jones: Encyclopedia - History and Technique-2008).

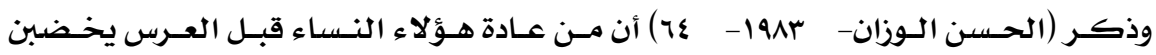

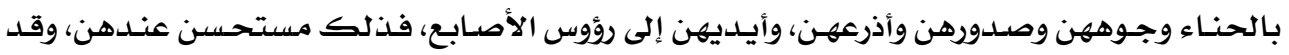

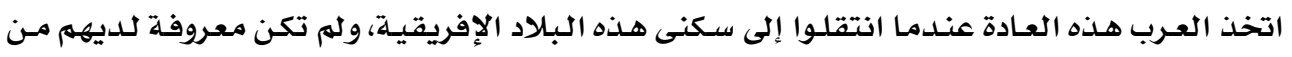

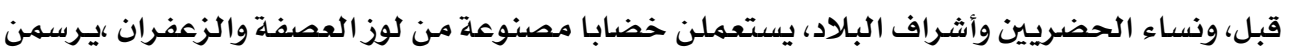

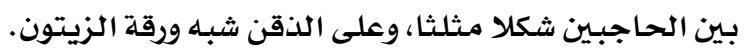

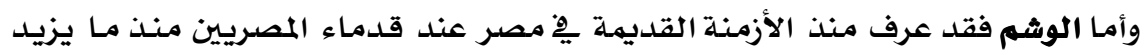

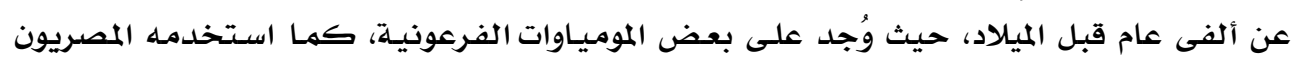

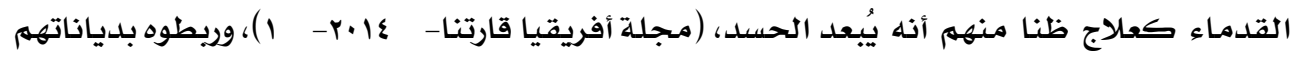
واستخدموه أيضا للزخرفة والتجميل (بركات محمد مراد-

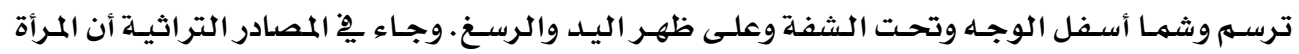

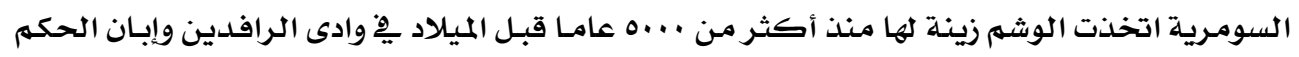

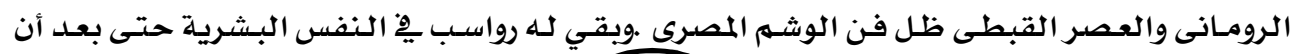


تطور المجتمع الإنسانى، إلا أنه ظل متشبثا به ،رغم ما بلغه من تطور، لم يستطع أن يتحـرر تمامـا مـن

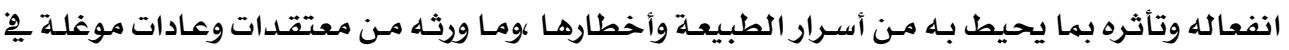

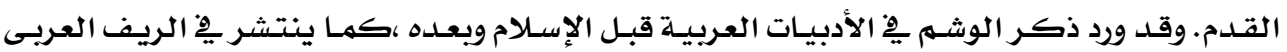

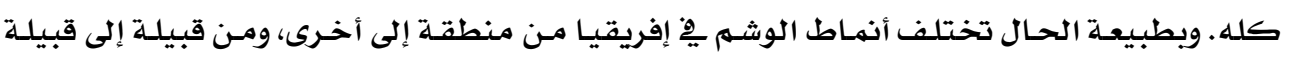

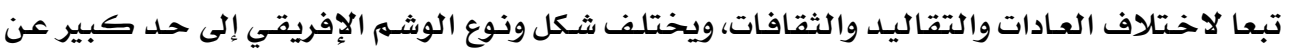

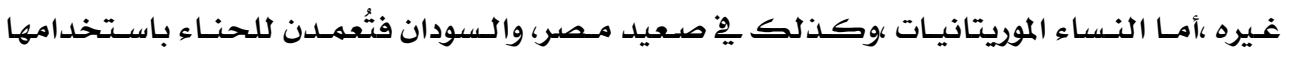

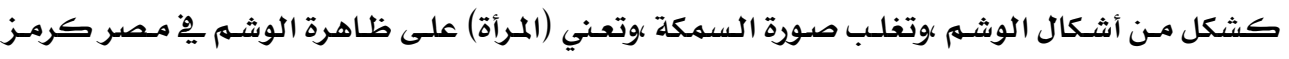

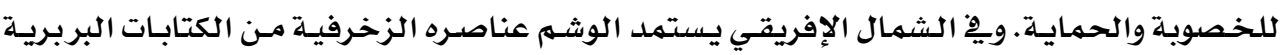

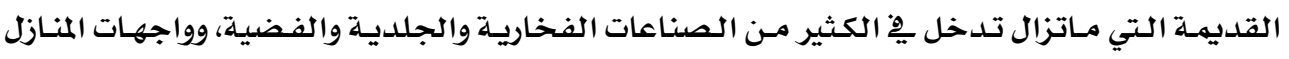

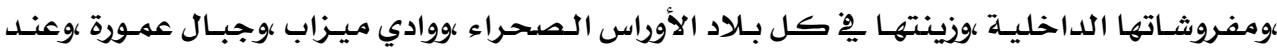

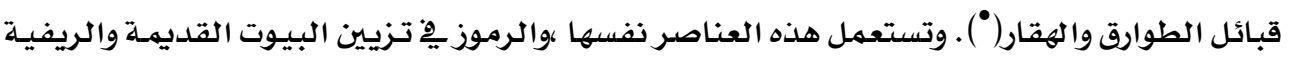

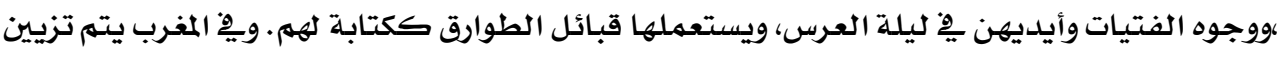

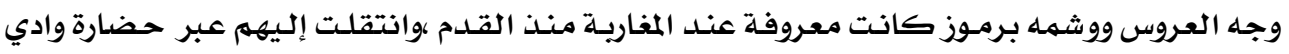

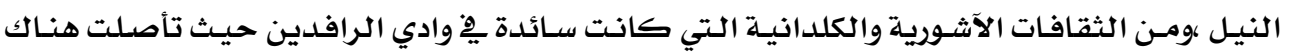

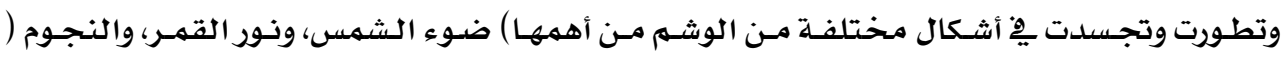

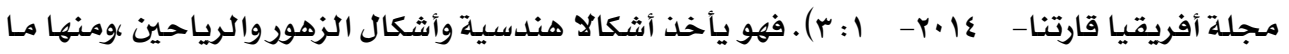

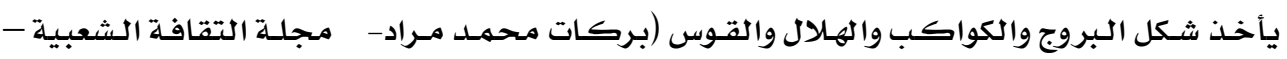

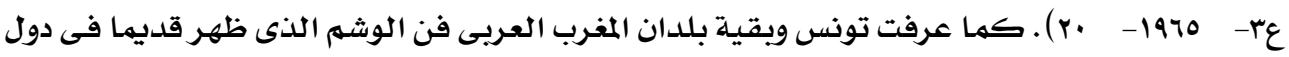

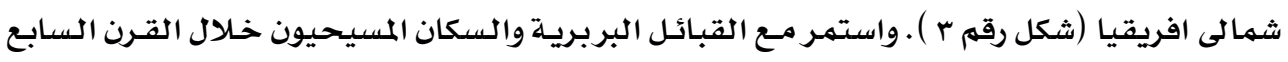

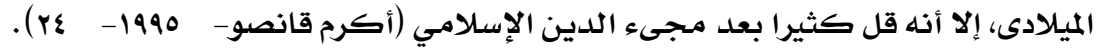
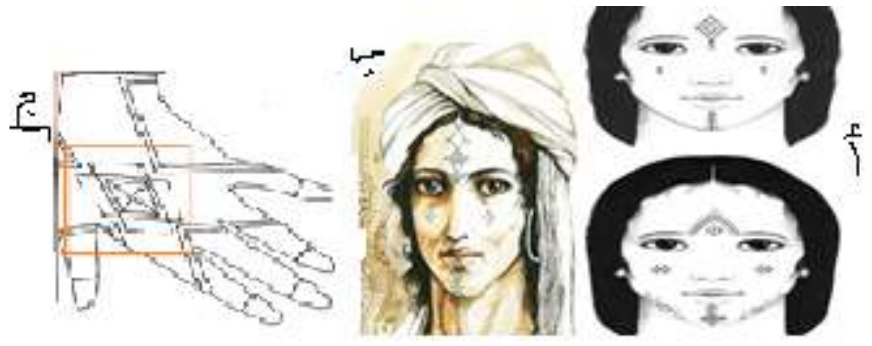

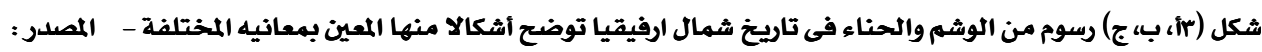

Catherine Catherine Cartwright-Jones-The Henna Page "HowTo" North African

Henna is provided free-2006, 2007, 2008,-p5 Harquus -vol2-p28

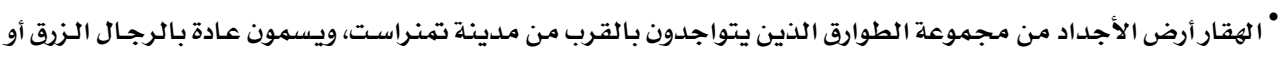

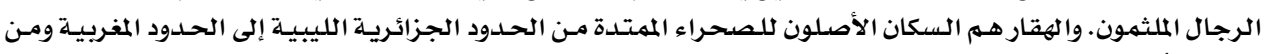

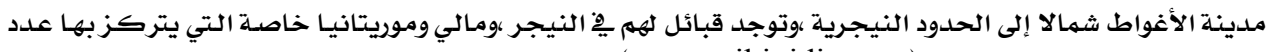

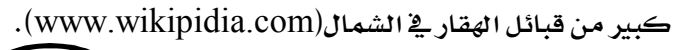




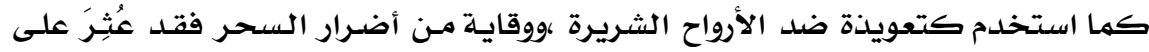

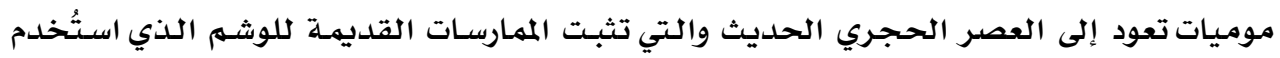

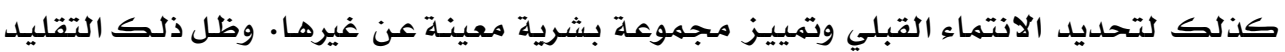

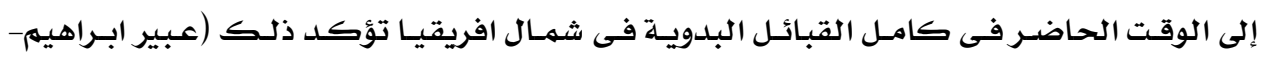

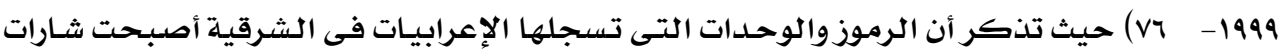

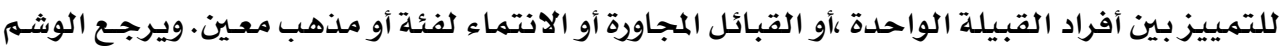

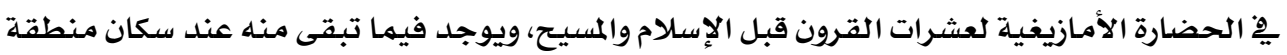

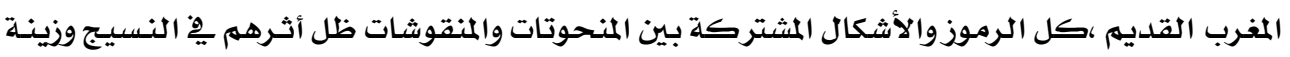

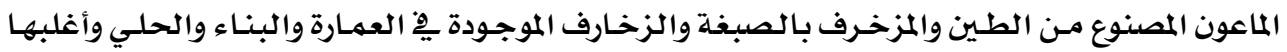

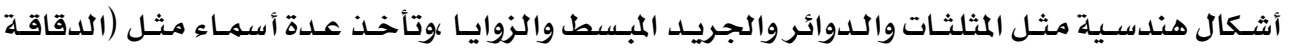

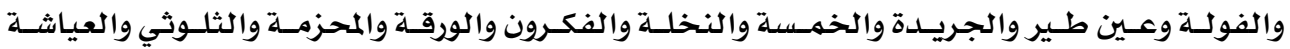

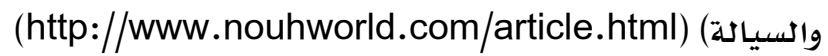

ولإجابة على تساؤلات البحث: بالنسبة للتساؤل الأول والذى نص على : ما درجـة تمثيل

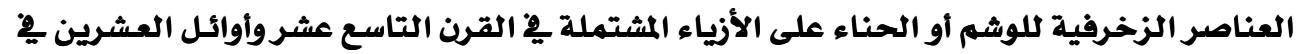
ثمال افريقياء

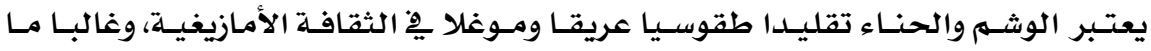

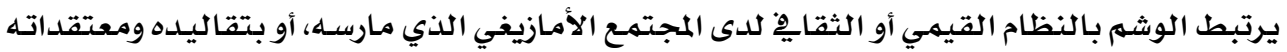

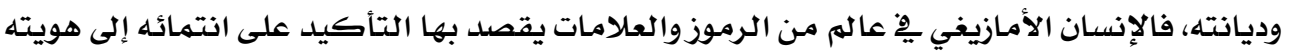

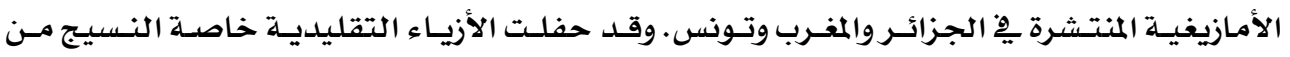

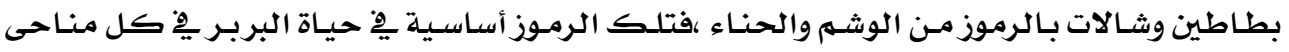

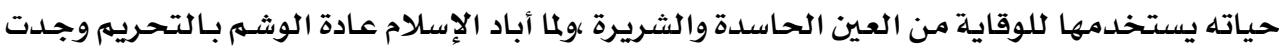

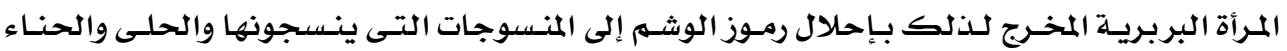

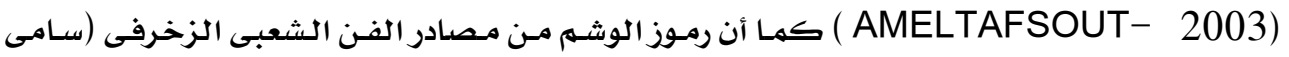

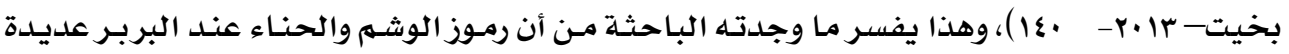

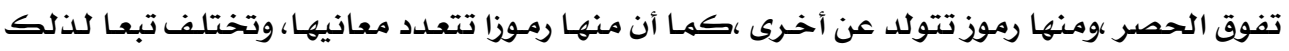

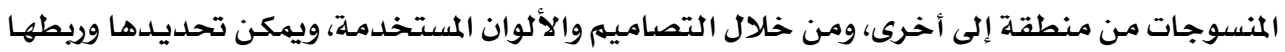

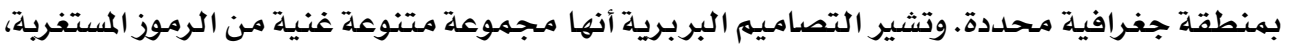

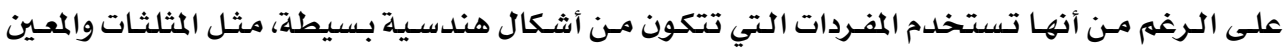

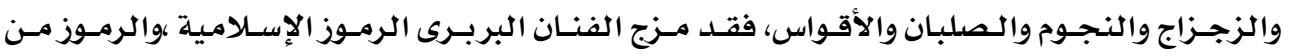

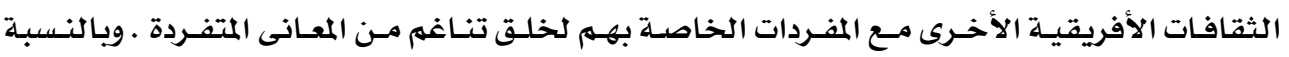

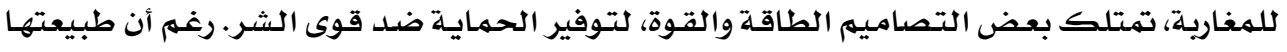

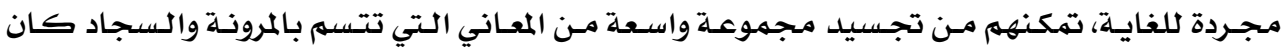

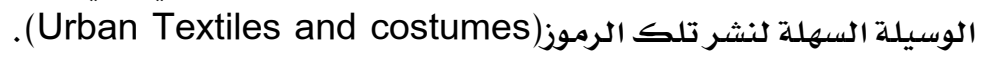




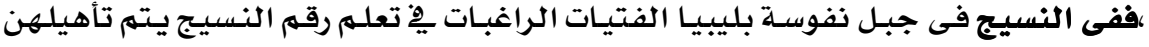

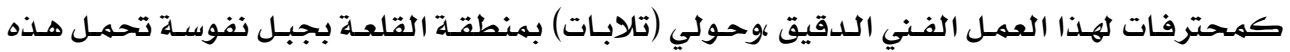

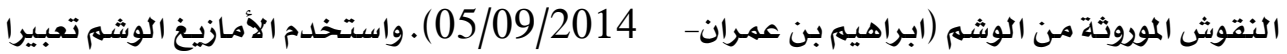

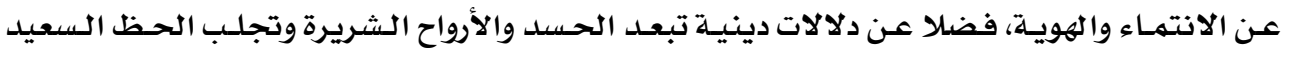

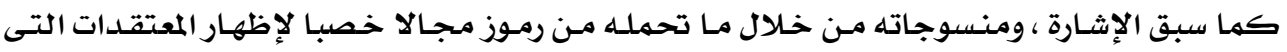

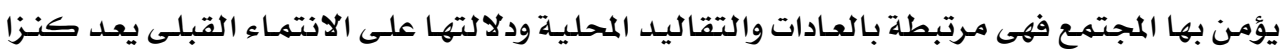

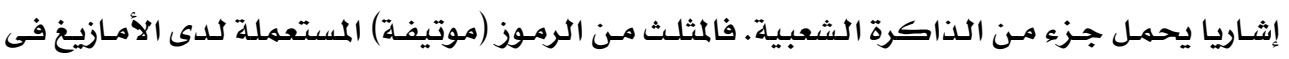

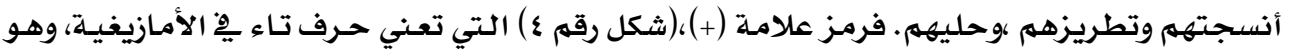

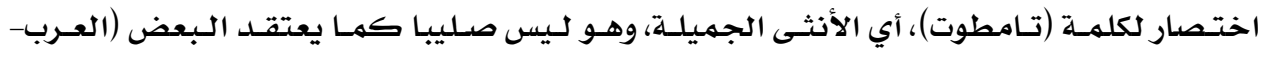
.) $r$. $-r \cdot 10$

وترى الباحثة أن هذا الرمز للغرزة المتقاطعة المنتشر عند بلدو مصر فى صحاريها فى سيناء

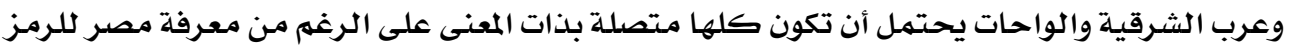

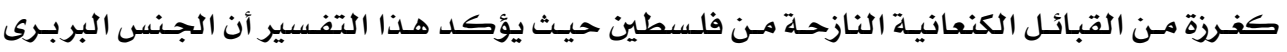

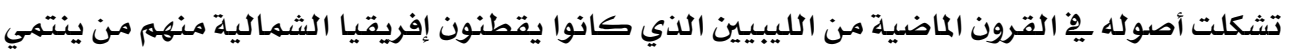

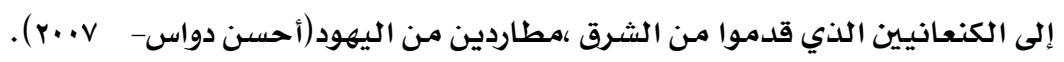

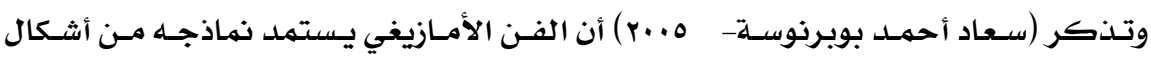

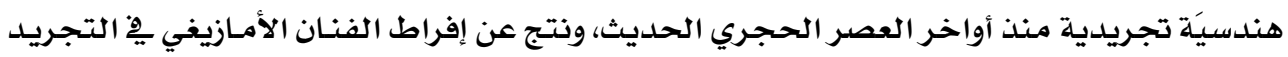

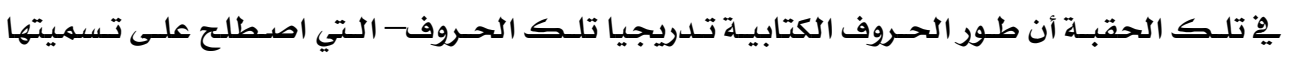

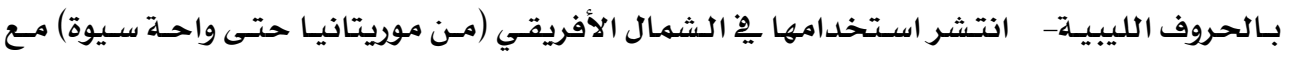

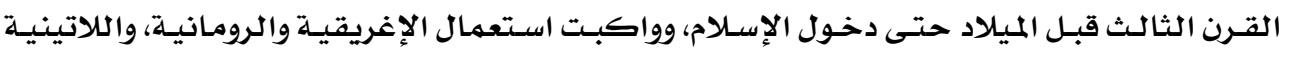

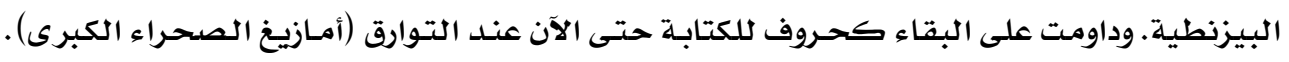

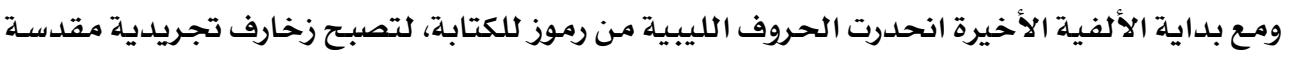

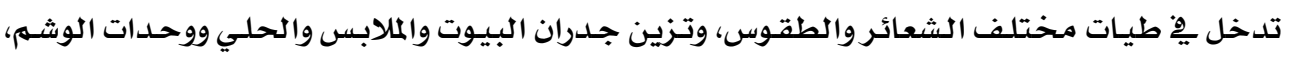

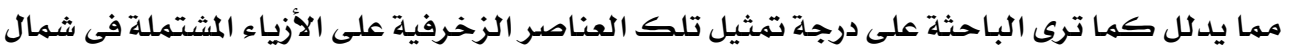

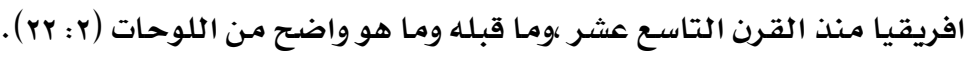

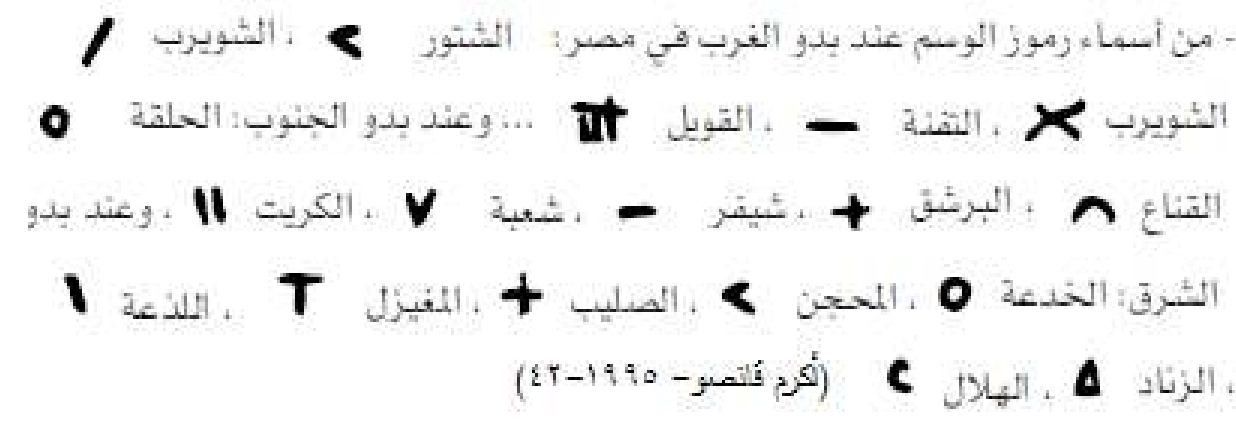

\section{ro.}




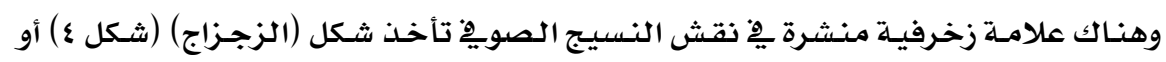

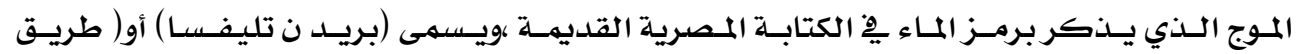

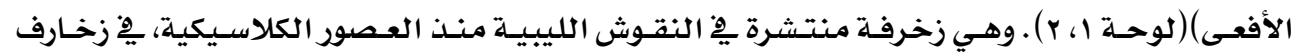

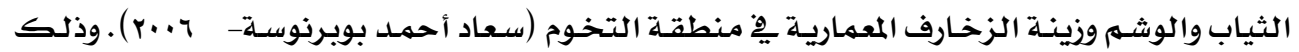
النقش يلاحظ وجـوده على كل ملابس البـدو ويسطهم والأكلمهـة مـن كامـل شمـال افريقيا شـاملا

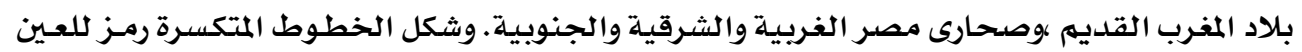

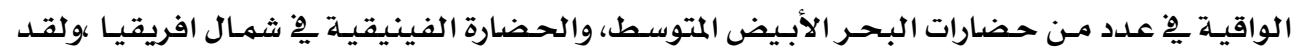

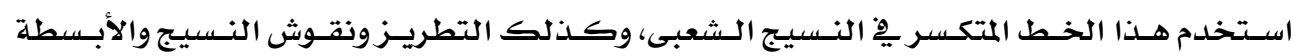

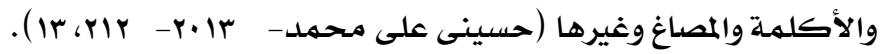

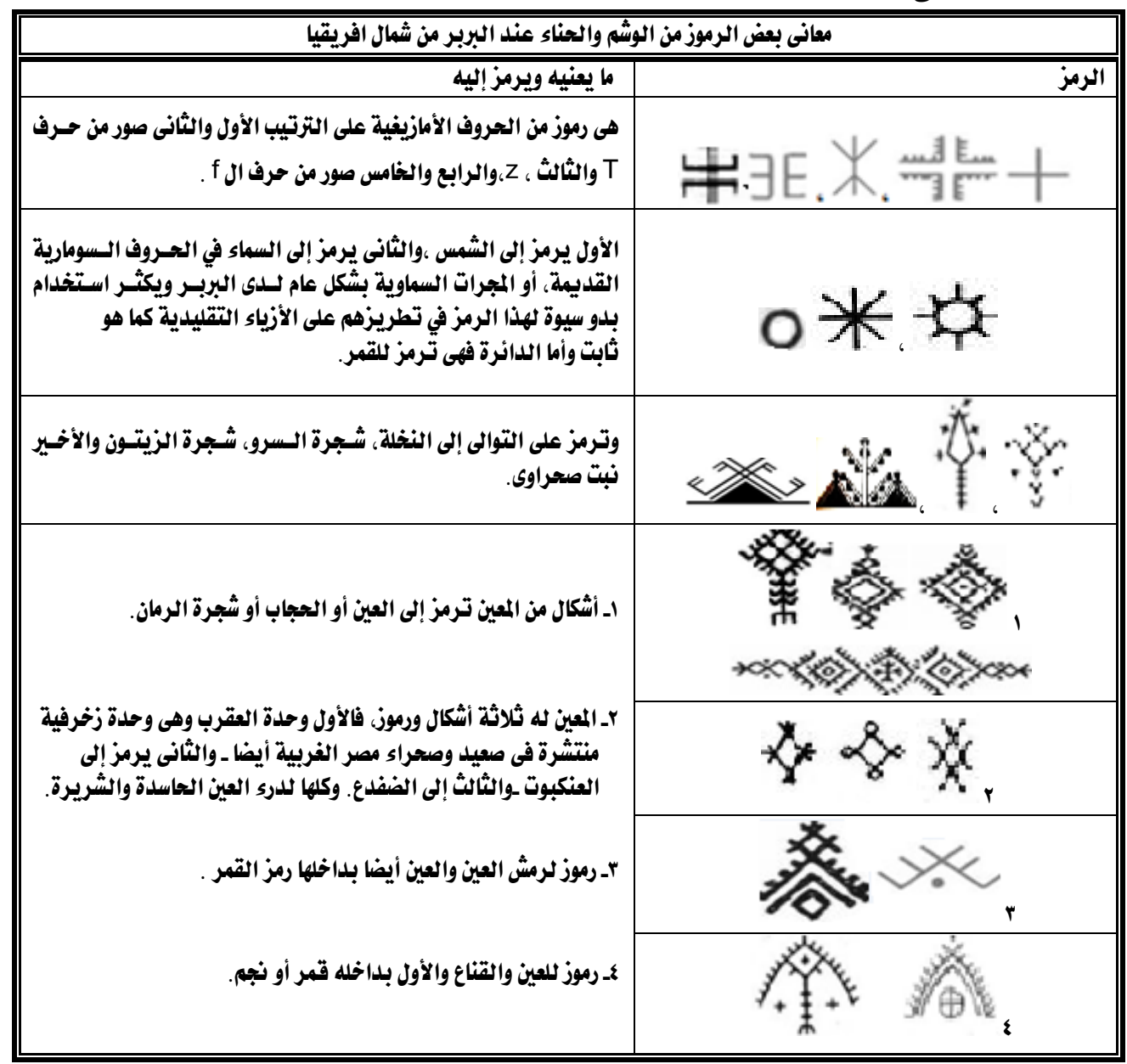




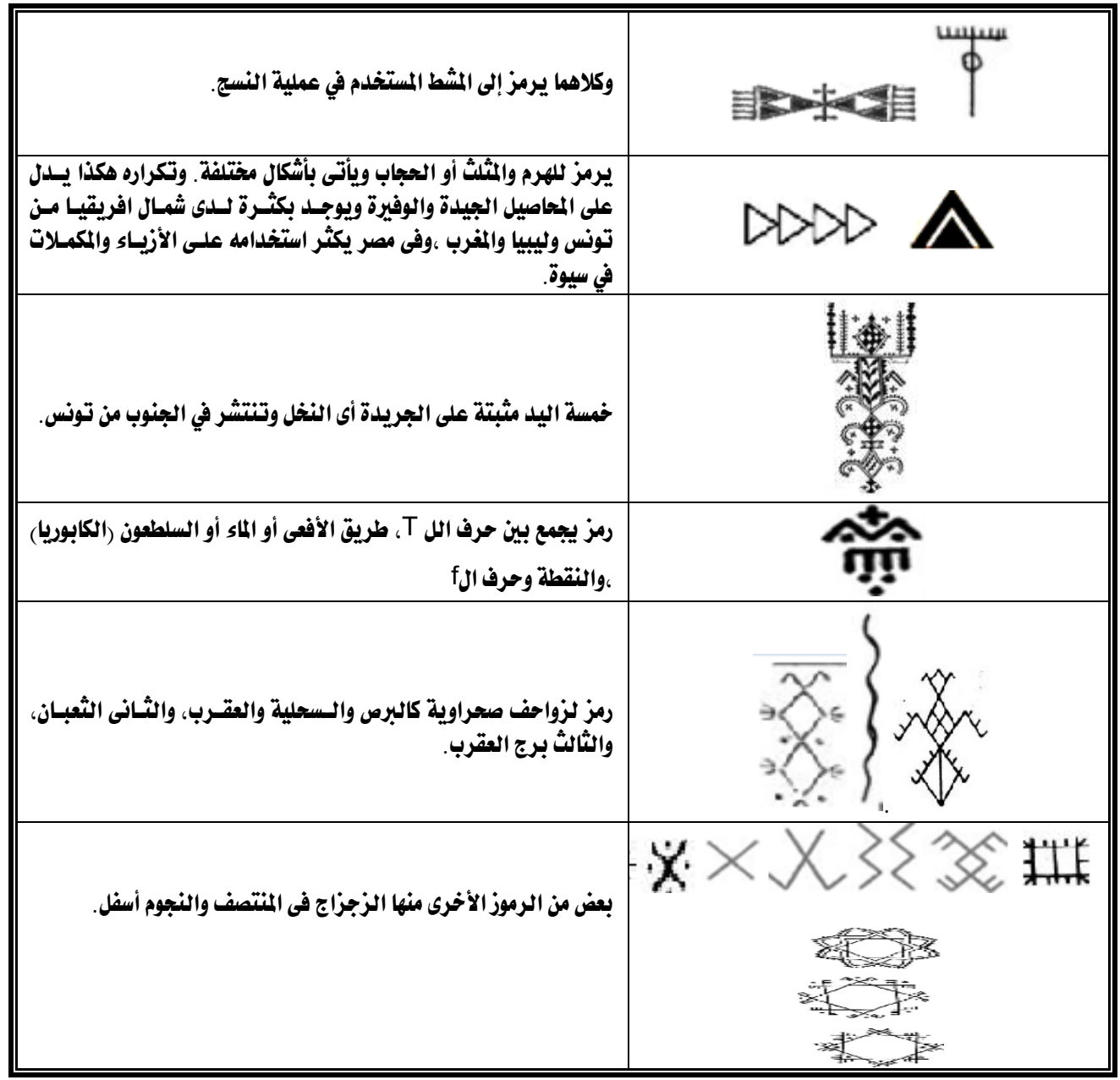

شكل (ع) جدول يوضح بعض من رسوم من الوشم فى شمال أفريقيا وما ترمز إليه المصدر: www.pinterest.com.www.encyclopedieberber.com,

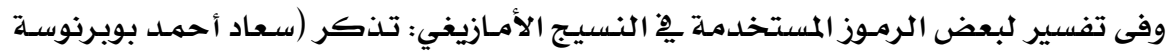

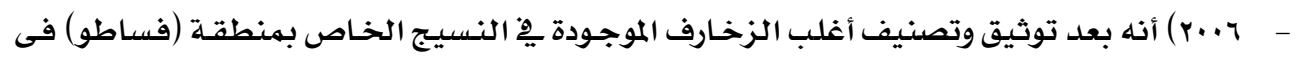

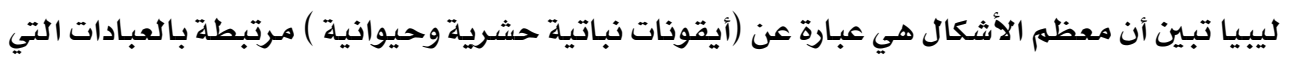

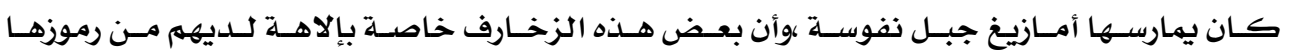

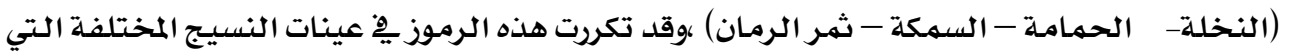

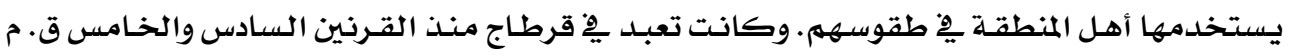

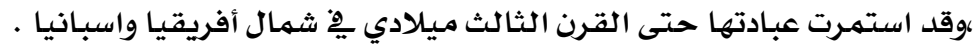


(نانا مرارا) حشرة يعتبرها سكان جبل نفوسة مقدسة (لوحة ا ) تكثر يِّ الربيع وأول الصيف

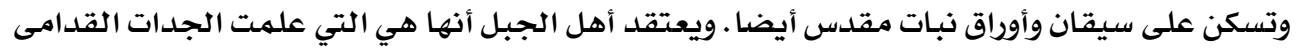

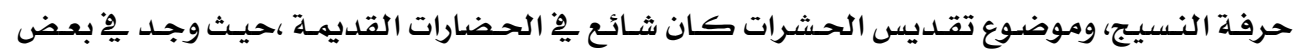

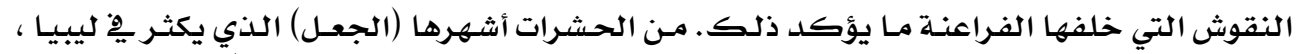

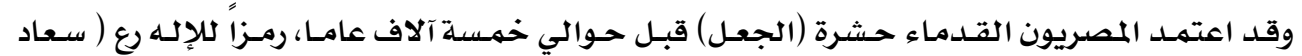

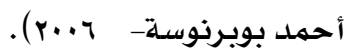
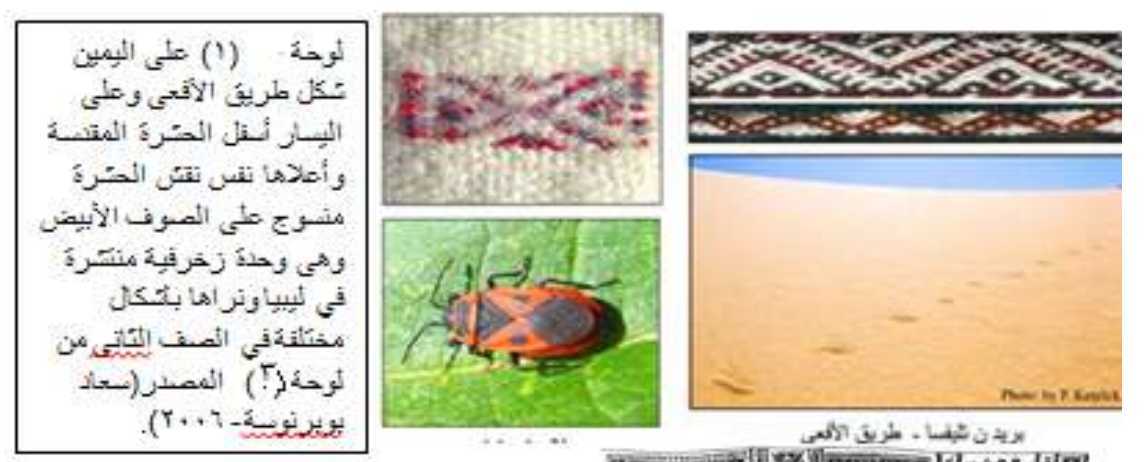

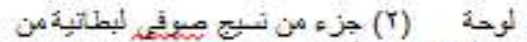

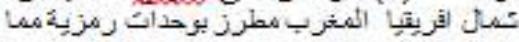

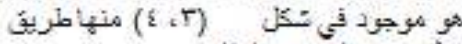

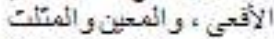
ألمسدر. www.pinterest.com

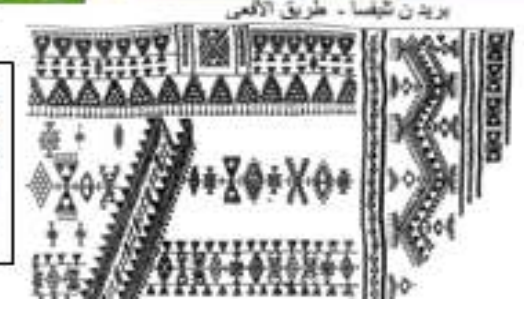

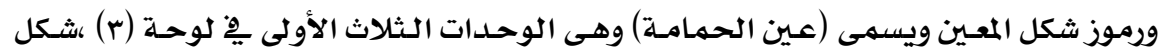

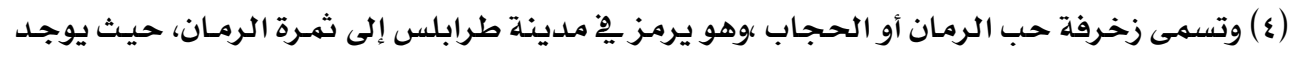

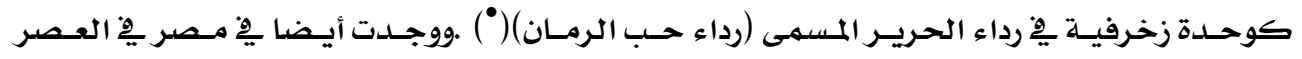

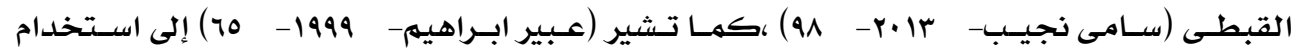

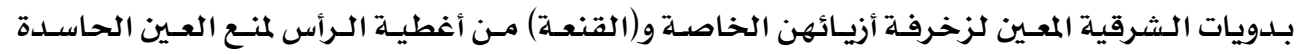

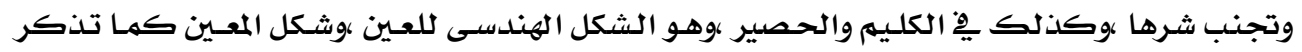

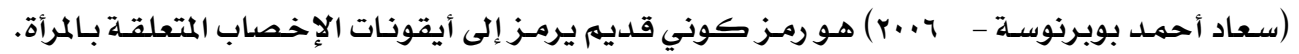

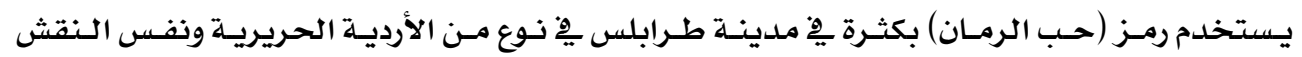

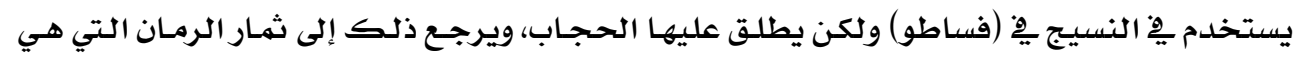

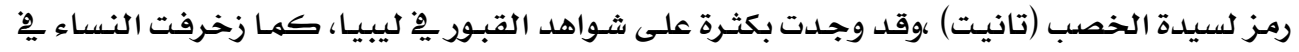

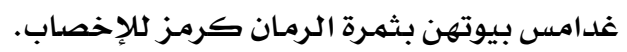

• يمكن الرجوع إلى (هبة أحمد يس: أزياء العرس التقليدية فى ليييا- Y ( ب ). 


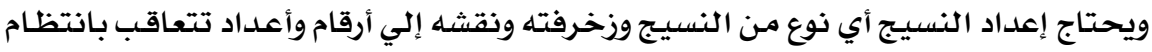

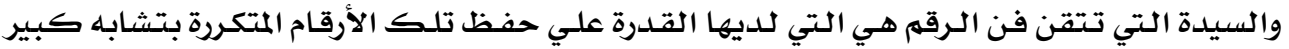

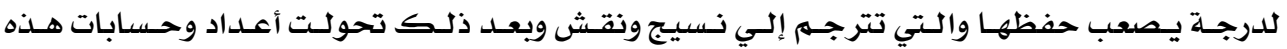

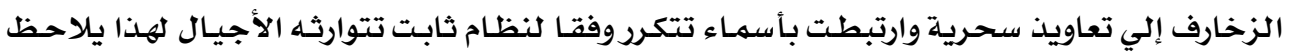

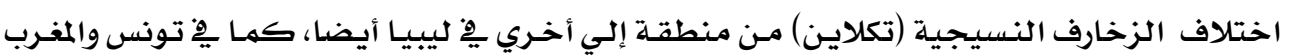

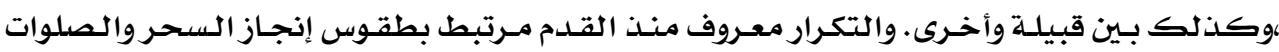

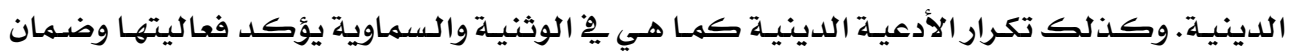

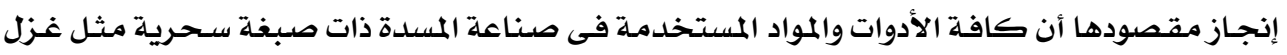

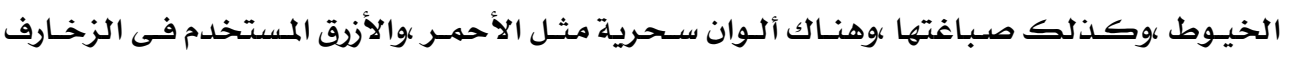

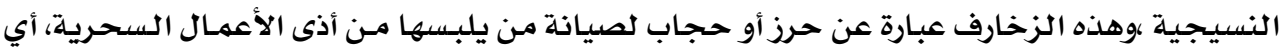

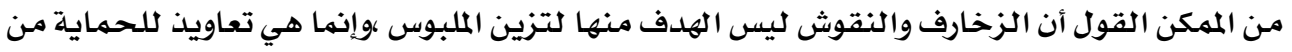

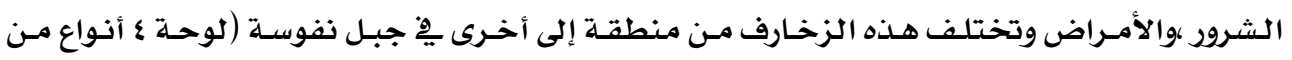

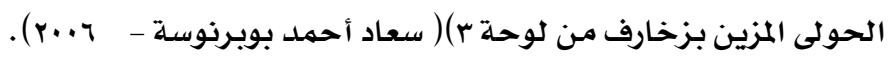
أشكال الززخارف النسبجية (تكلنايسين)

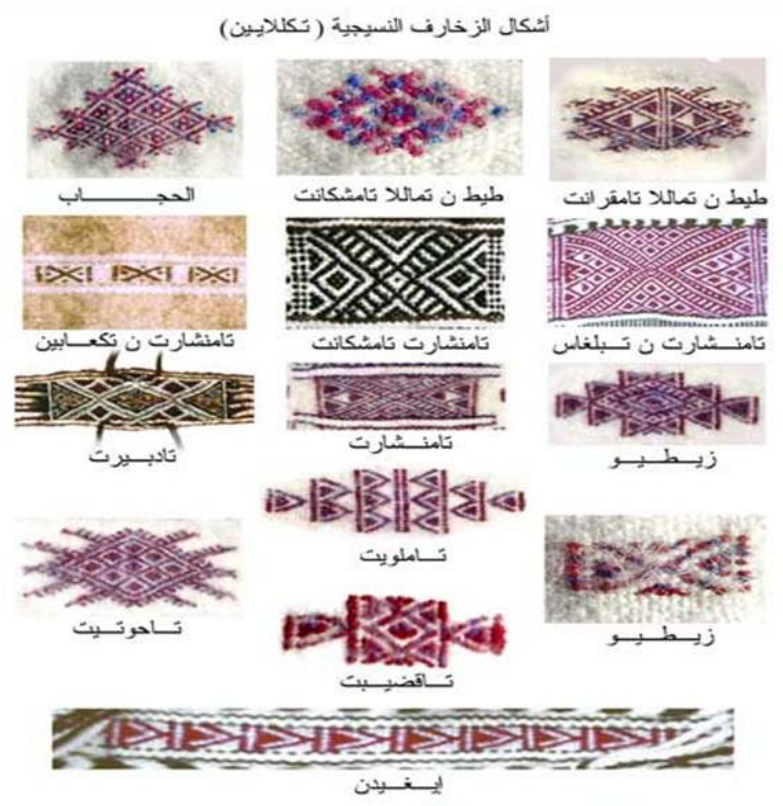

لوحة (r) أثكال للزخارف النسيجية يِّ جبل نفوسة بليبيا الثلاث الأولى منها لشكل المعين أو الرمان أو الحجاب

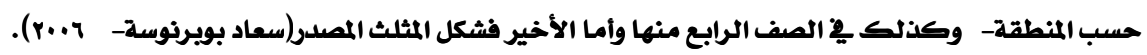



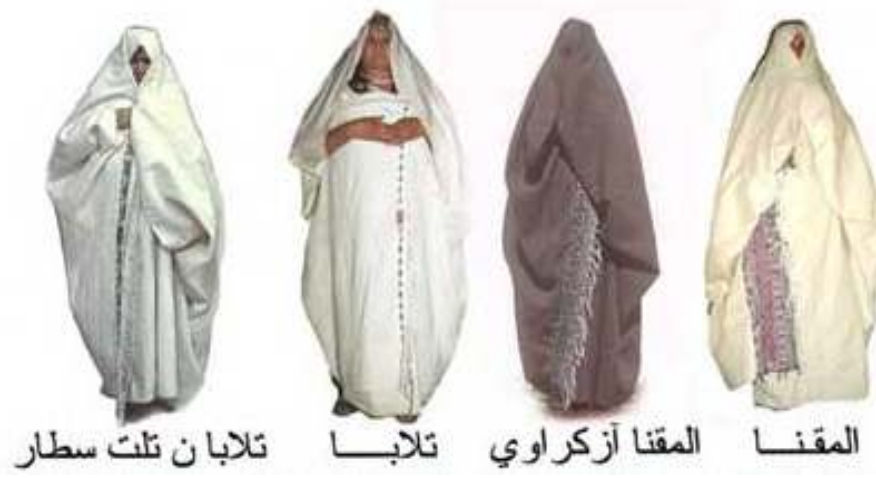

لوحة (ع) نساء من ليبيا يرتدين حولى المناسبات من الصوف الأبيض أو البنى وأطرافه مزينة بزخارف النسيجية

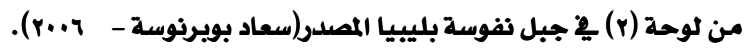

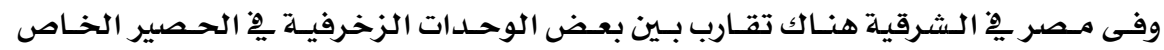

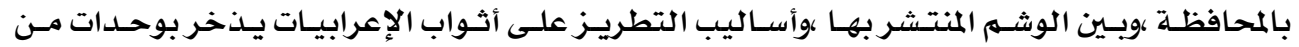

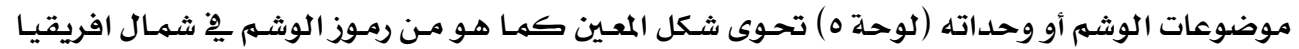
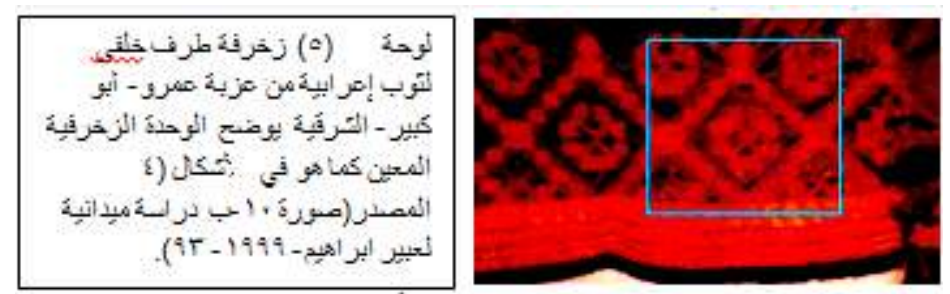

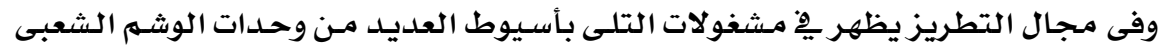

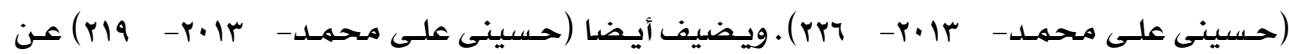

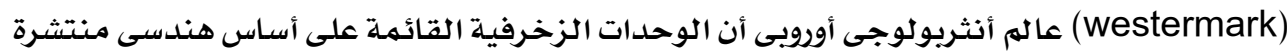

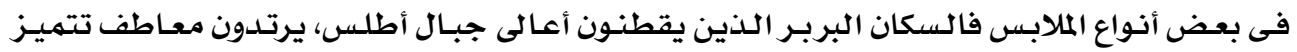

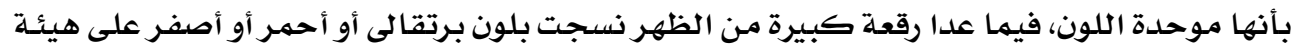

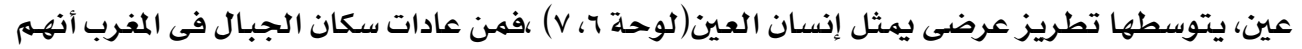

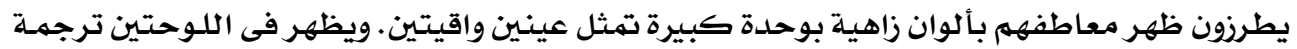

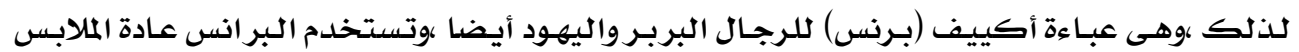

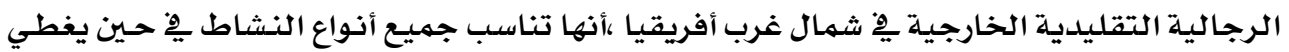

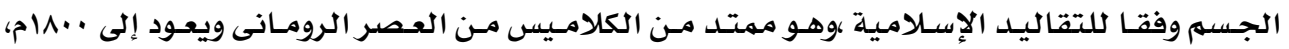

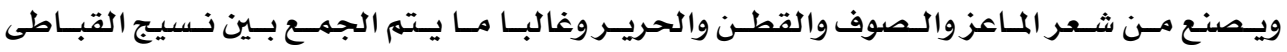

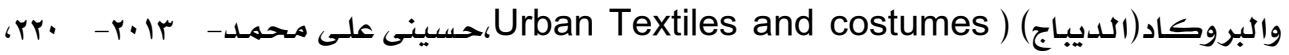

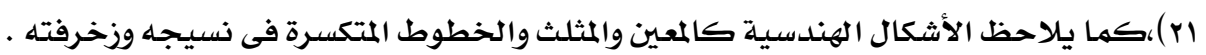



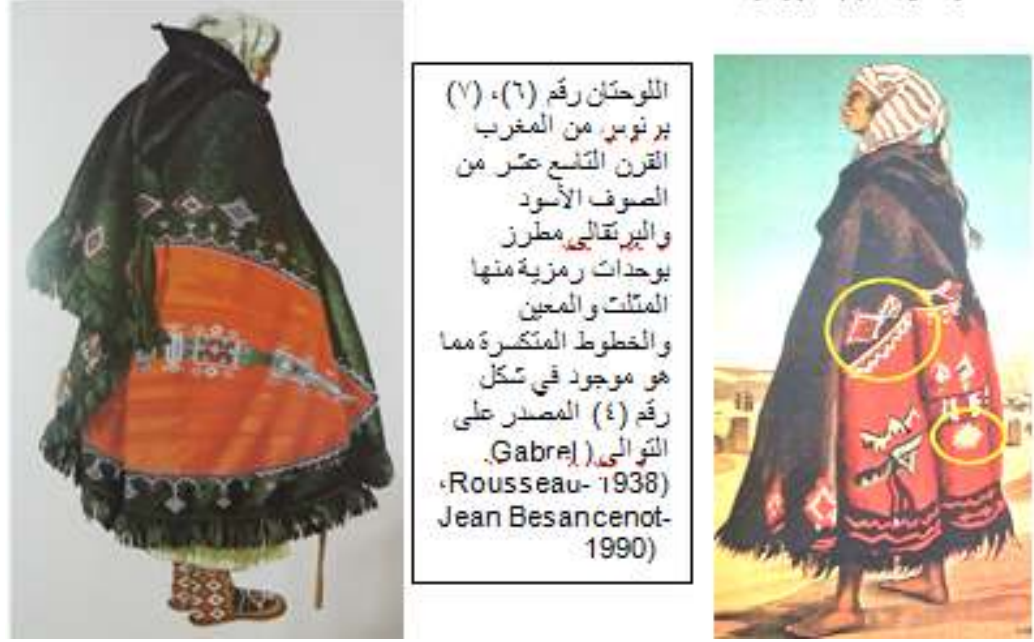

وفى الرموز الشعبيـة العربيـة يِّ شهـال افريقيـا يرمـز أحيانا إلى العـين الواقيـة بشكل المثلـث

(شكل ع)، وقد يكون هذا الإيجاز يخ التعبير عن العين راجعا إلى لزوم التكييف بإمكانيـات النسيـج ،مهـا يضطر الوحسدات بـالالتزام بالطـابِع الهندسى، غـير أن المثلث الـذى يكثر فِ النسسيج سـرعان مـا يحـور ويصبح مجرد خطين متقاطعين كرأس مثلث ليست لـه قاعدة واطتفى بوضـع نقطة مكانها، كهـا

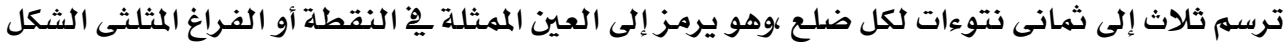

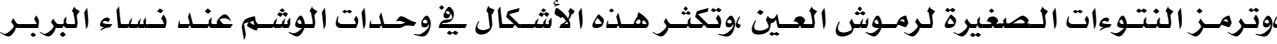

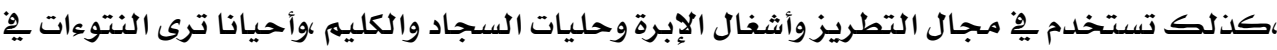
بعض حليات النسيج دوائر متر اصسة أو غير ذلك مـن تصرفات تتفق وإمكانيـات كل نوع مـن النسيـج

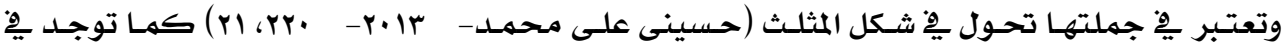
زخارف الحناء (Catherine Cartwright Jones ..Henna is provided free).

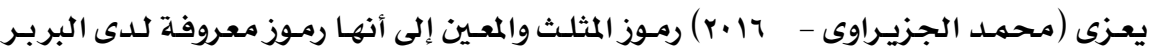
السكان الأصليـين، والمثلث كهـا هـو معـروف عند كل الشعوب يرمـز للعـدد ثلاثلة ،والمثلثين متقـابلى الرأس هو رمز (إيدك فى إيد أخوك) وتراها البـاحثة حاضرة بقوة فى تاريخ البـدو المصرى فى صسحارى الواحات الغربية كسيوة ،وأيضا النوبـة ،وإن كان متسـاو الأضلاع فيرمز للسهو والانسجام، وإن كانت قمته لأعلى فهو يـرمـز للنـار والـذكورة ،وإن كانت لأسـفل فيرمـز للمـاء والأنوثة، أمـا المعـين فهو روـز الأنوثة عادة ،عندما يكون مهدد الشكل يدل على التواصل والتبـادل (كما توضتح الصورة أقصى اليسـار الصف قبل الأخير فى اللوحة r) ،وأما الرسوم الهندسية المختلفـة فهى مـن تأثير حكم الأتراك ،بينهـا

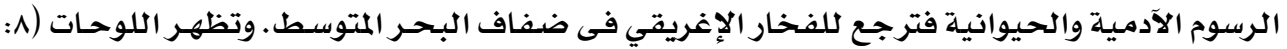
• 1) زخارف هندسية تعتمد على المثلث والمعين ، الأوليـان بـرانس (أكيـف) مـن القـرن التاسـع عشر مـن المغـرب صسنعت مـن الـصوف الـسهيك الخـشن ،أولهمـا بنى مسشغول بـالخيوط الـصوفية البيـضـاء وبـها (رقعة العين الخلفيـة الممـيـة لـه) ،والآخـر مـن الصوف الأبـيض بلونه الطبيعى مطـرز بخيوط صسوفية 
ملونـة غالبها الأصفر والأخضر والبنسى، كلاهمـا تزينـه وحسدات رمـزيـة منهـا المثلث والمعـين ذو المعـانى

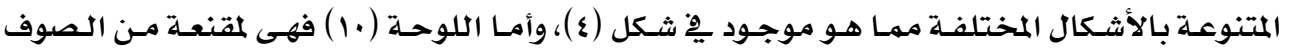

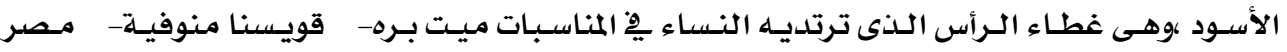

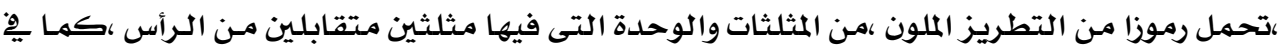

شكل(ع) ).

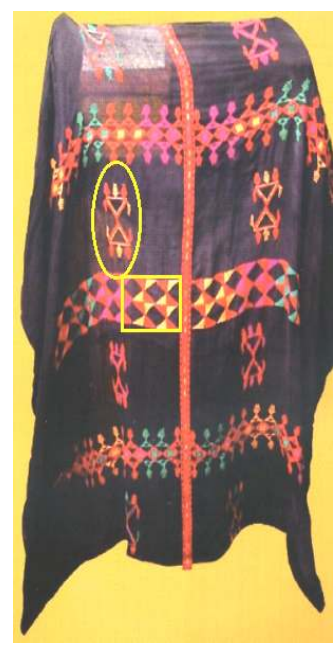

لوحة ( ـ ) مقنعة غطاء رأس من ميت بره

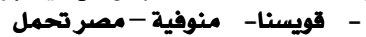
رموزا من المثلثات وشكل مشط النسيج")

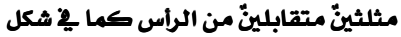

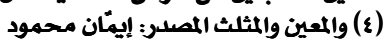

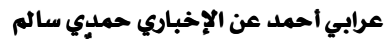
حسن: المأثورات الشعبية م r\&/II/Y\&\&4

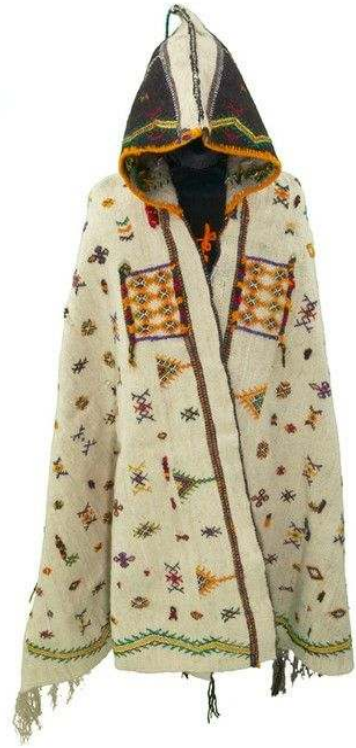

لوحة (9) أكييف أو عباءة (العين الحمراء) برنوس من المغرب جبال أوبال أطلس (العين

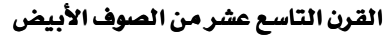

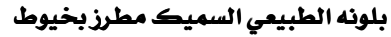
صوفية ملونة غالبها الأصفر والأخضر

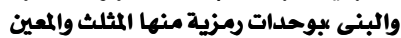
باشكال مختلفة ترمز إلى رموز مختونة المتلفة

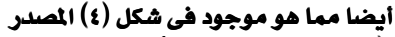

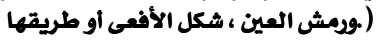

على النيل - Gabrel Rousseau-

Jean Besancenot-1990)، 1938)

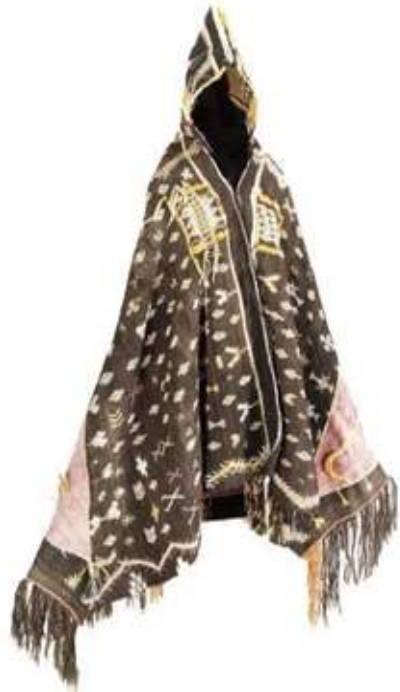

لوحة (ه) أكييف أو عباءة (العين

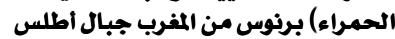

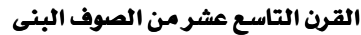
السميك مطرز بخيوط صوفية المبوفية بيضاء، اليني،

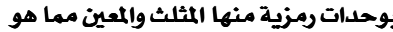
موجود يخ شكل (ع) المصدر ( Gabrel (1938). Jean ،Rousseau- 1938) Besancenot-1990)

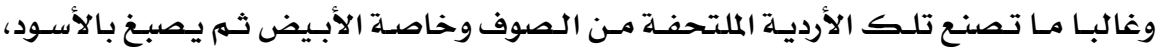

وتطـرزبالخيوط القطنيـة غالبـا البيـضاء التى تـرك على لونها الطبيعى ،بأشـكال هندسيـة متتنوعـة غالبا مـا تترتب فى مـركز القطعة ذات الشكل المستطيل ،وعلى أطرافها بحيث تكون مـرئية على الـرأس

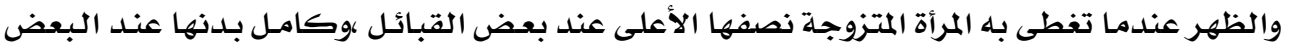

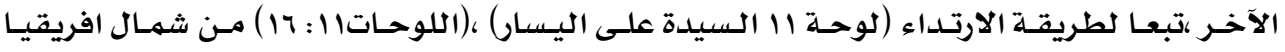
،وحدة المثلث والمعين هى الأسـاسية كها أشـار (الجزيراوى) فى الزخارف وتتنـوع فى ترتيبها وتركيبها بشكل فيـ ابداع وجمال واضـح رغم بسـاطة وحداته، وهى شـالات من الجنوب التونسى ،وتسمى (مقدال) 
من أواخر القرن التاسـع عشر ،مصنوعة مـن جميعها مـن الصوف عدا لوحسة (10 ) مـن القطن ،وألـوان

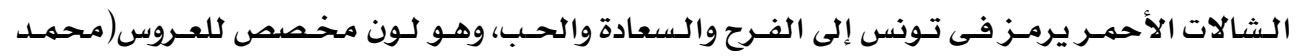

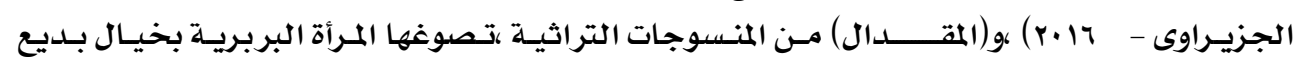

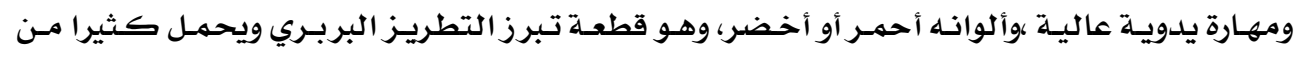

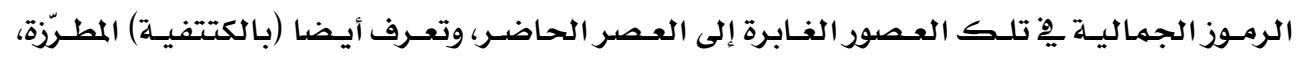

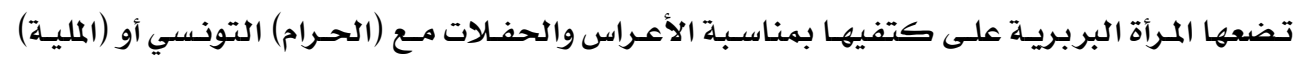

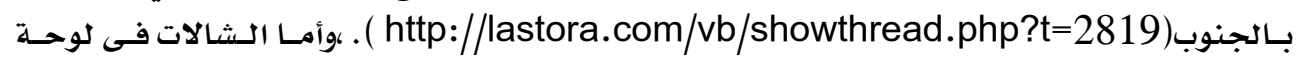

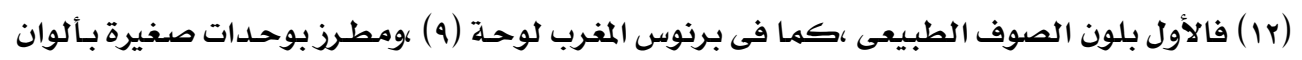

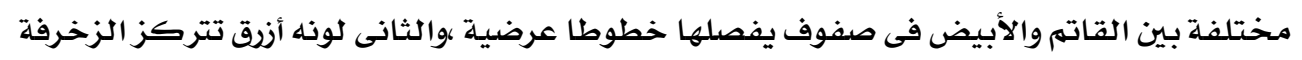

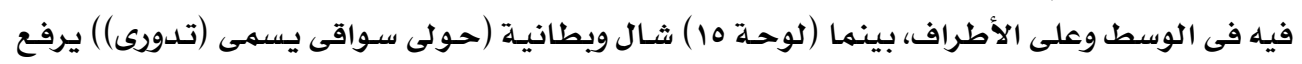

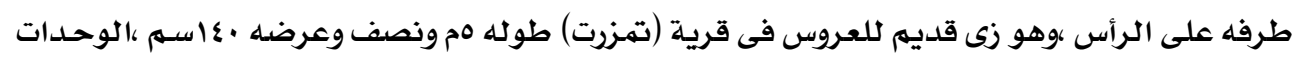

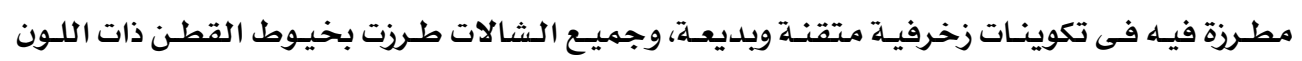

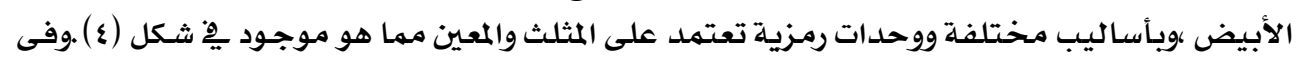

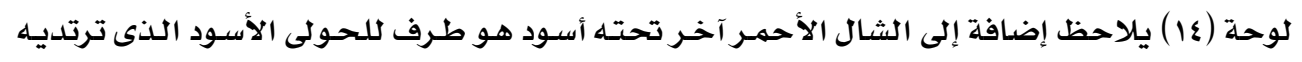

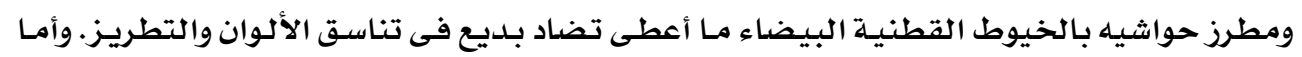

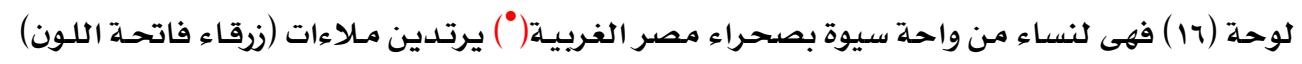

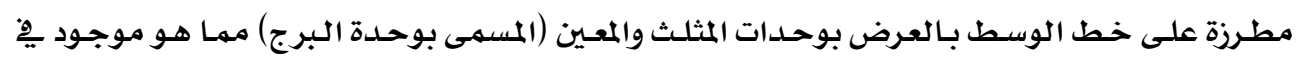

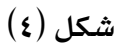

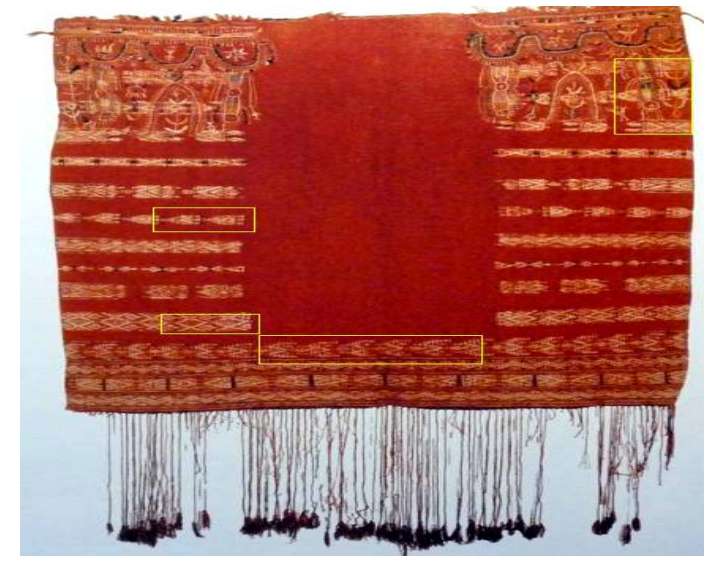

لوحة (11) شال وبطانية أواخر القرن التاسع عشر من الصوف الأحمر المطرز بالخيوط القطنية البيضاء الجنوب التونسى (1) مونى

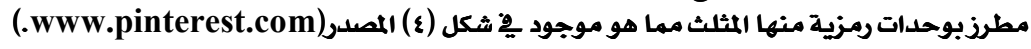

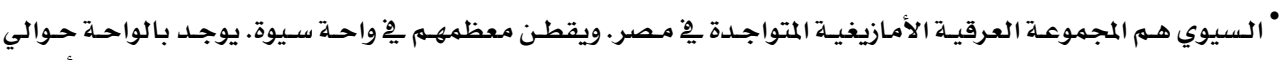

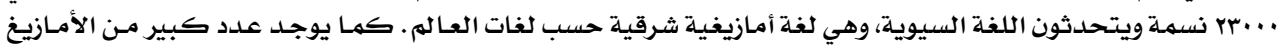
يخ قنا والذين ينتمون لقبائل الهوارة. (www.wikipidia.com - Siwa", Encyclopædia Britannica, 2007) 

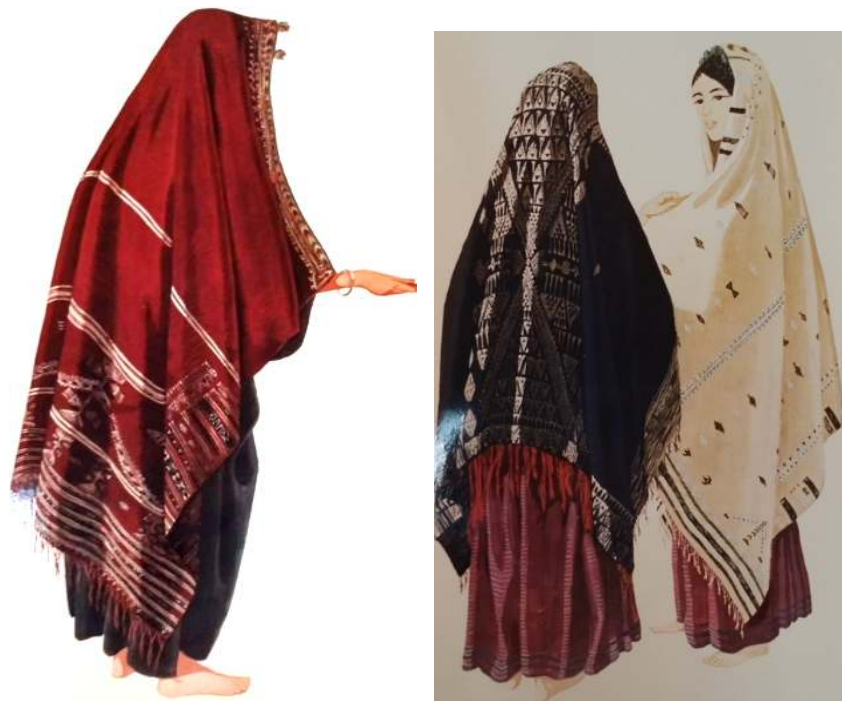

اللوحتان (r) ) (r) (1) شالات من الجنوب التونسى القرن التاسع عشر من الصوف الأول بلون الصوف الطبيعى والثانى بلون

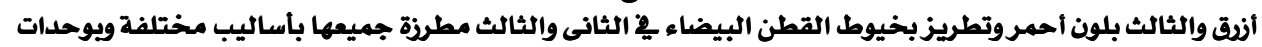

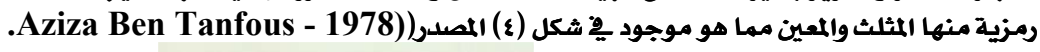
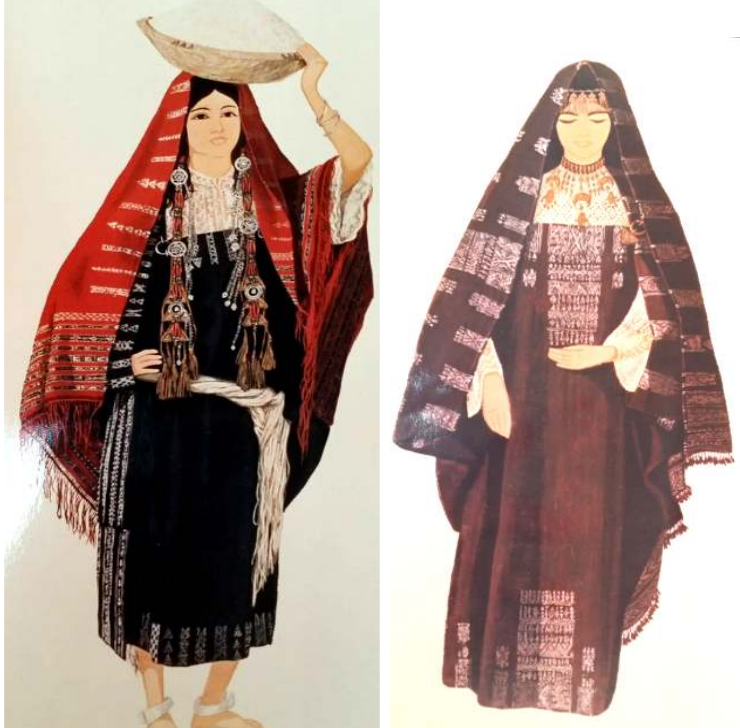

اللوحتان (ع 1)،(10) ثالات أواخر القرن التاسع عشر ا من الصوف الأحمر والأسود المطرز بالخيوط القطنية البيضاء

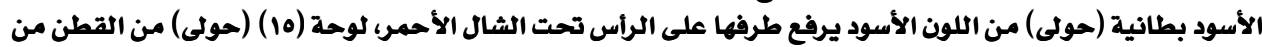

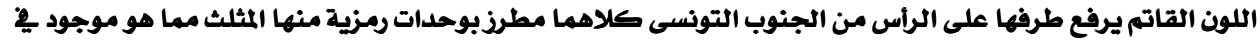

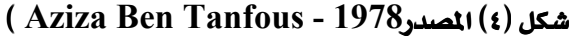


من كل ما سبق عرضـه تتضح درجـة تمثيل العناصر الزخرفية للوشهم أو الحناء على الأزيـاء

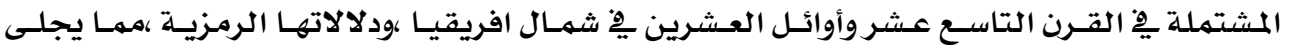

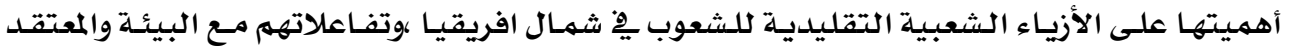

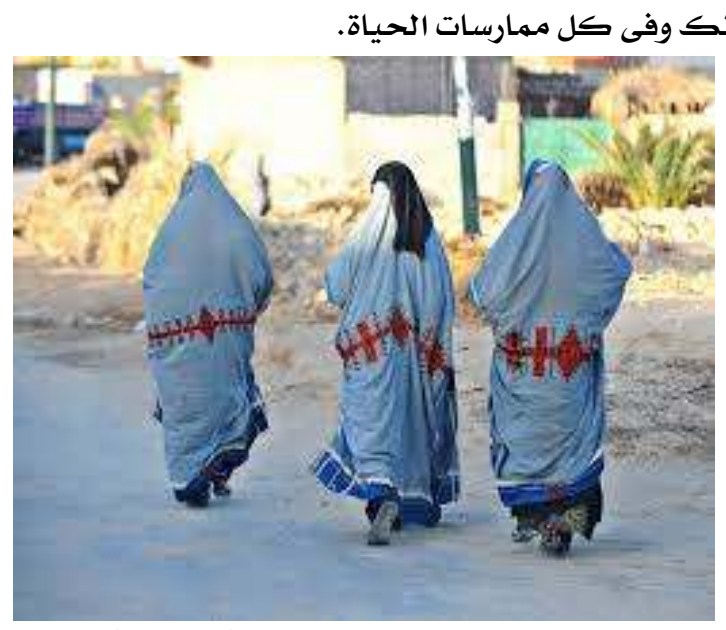

لوحة (1 ) نساء من واحة سيوة بصحراء مصر الغربية يرتدين ملاءات (زرقاء فاتح) مطرزة على خط الوسط باء بالعرض

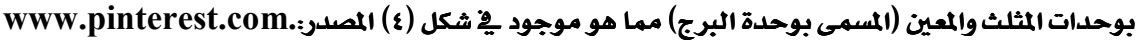

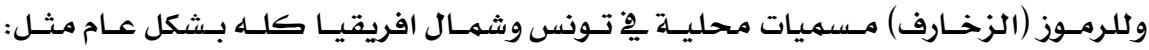

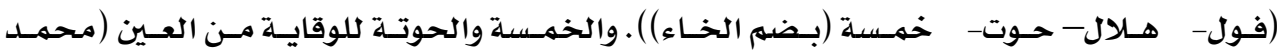

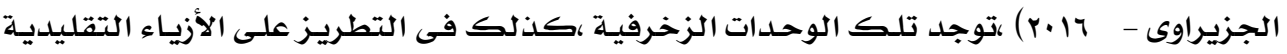

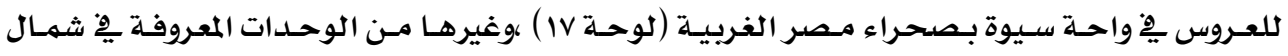
افريقيا، مثثلا

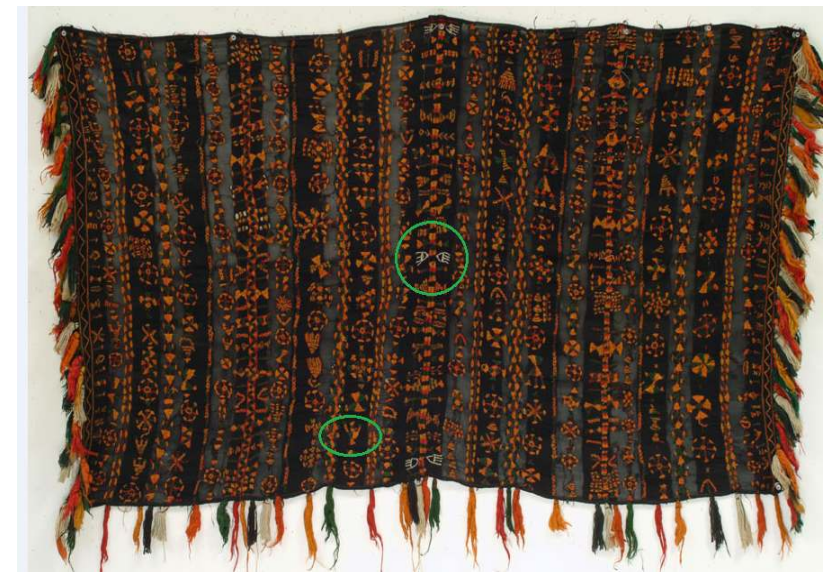

لوحة رقم (IV) شال (طرحة طرقعيت) القرن التاسع عشر من الصوف الأحمر من تونس مطرز بوحدات رمزية مما هو

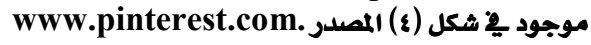




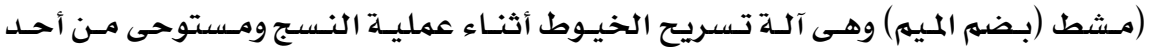

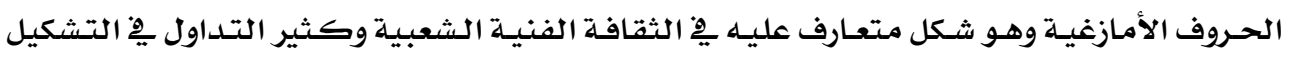

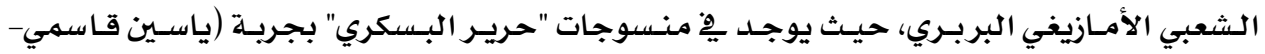

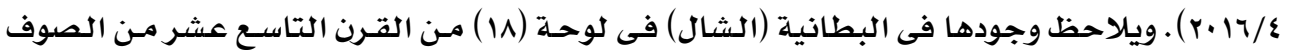

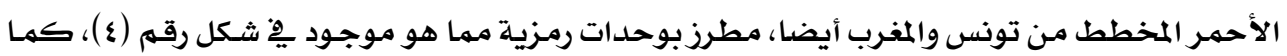

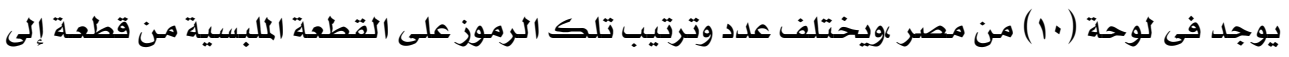

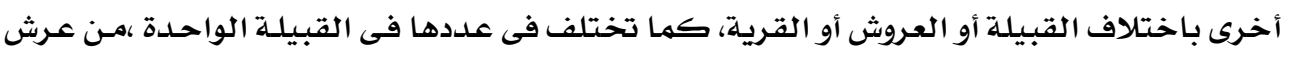

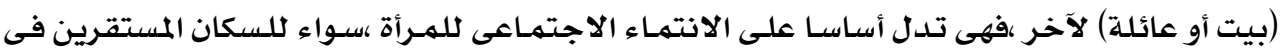

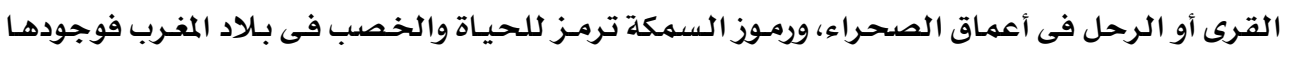

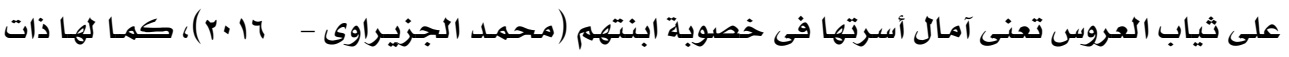

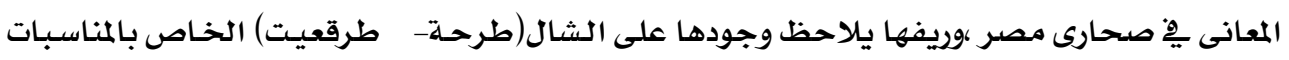

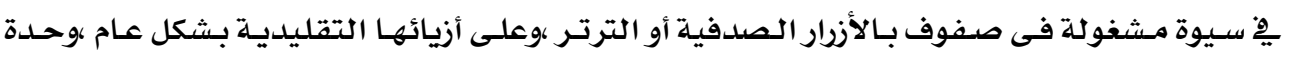

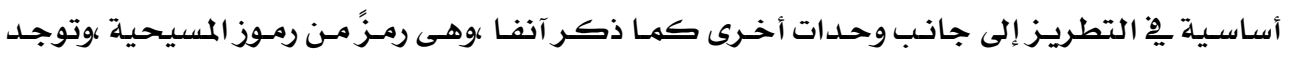

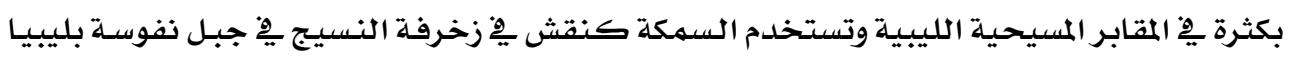

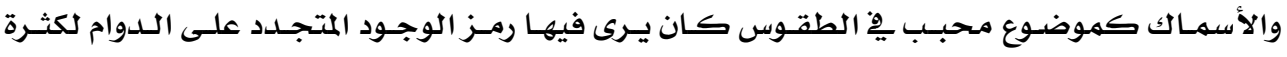

تناسلها.

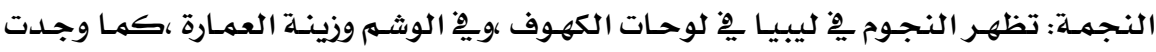

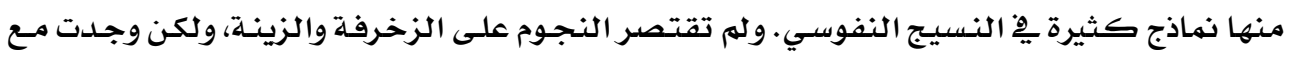

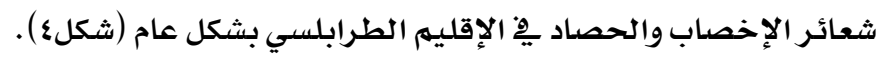

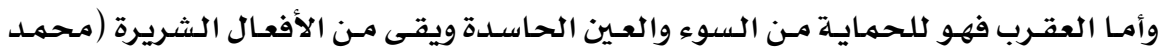

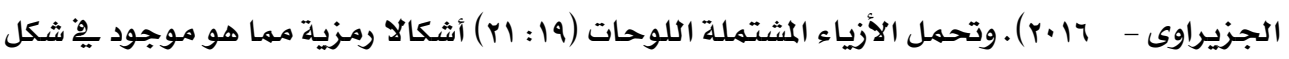

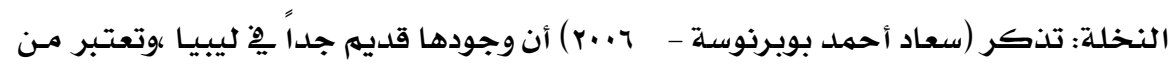

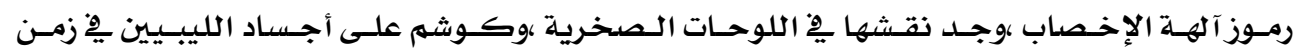

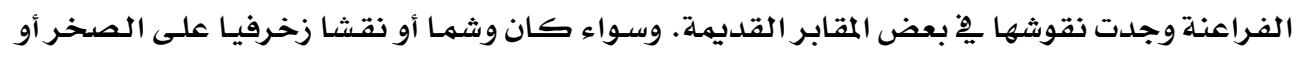

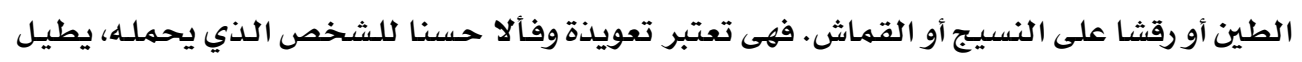

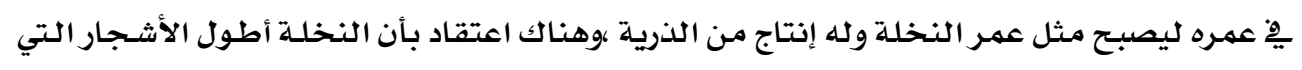

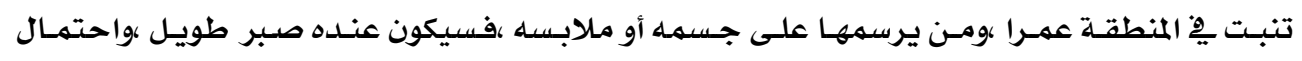

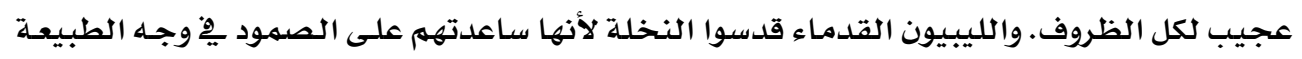

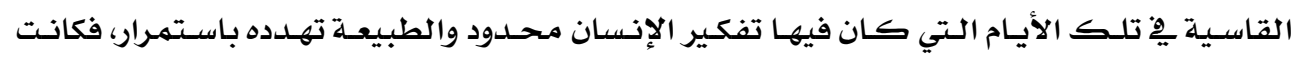

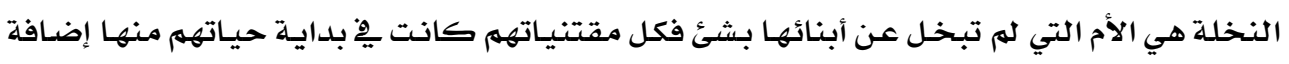




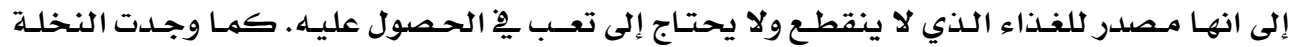
أيضـا وبذات المعانى عند البـدو يْ صدحارى مصر والريفيين فهى ترمز إلى النهاء والخصوبة (لوحةبr ).
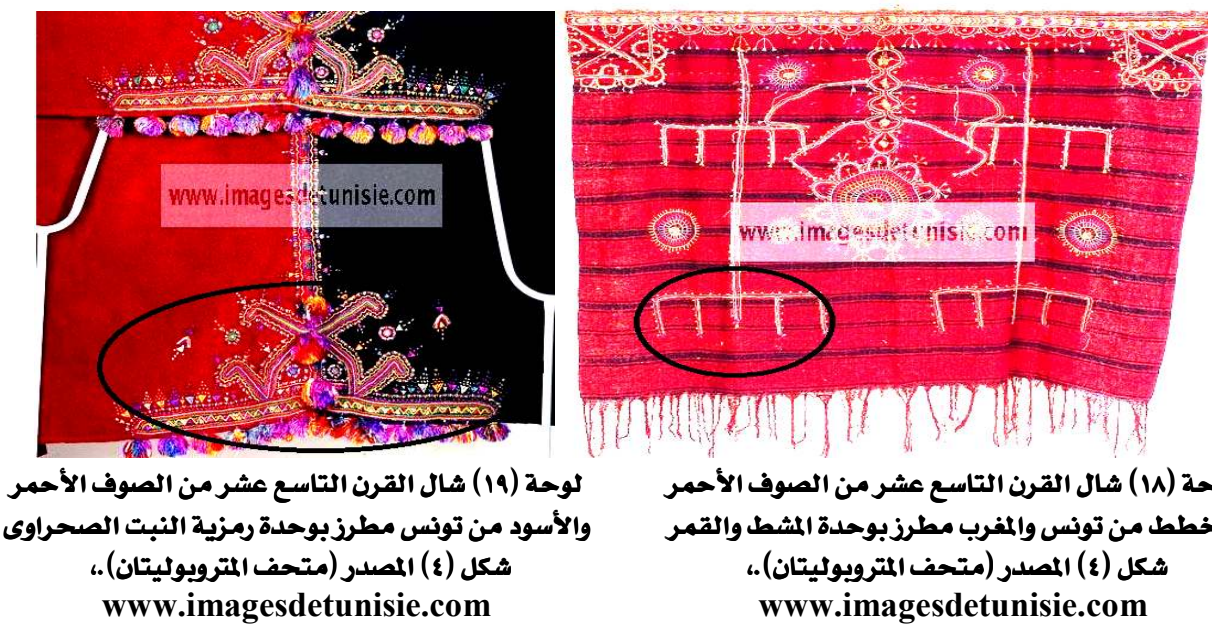

$$
\begin{aligned}
& \text { لوحة (1) ) ثال القرن التاسع عشر من الصوف الأحمر }
\end{aligned}
$$

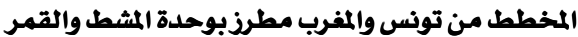

$$
\begin{aligned}
& \text { ثكل (ع) المصدر (متحف المتروبوليتيتان).، } \\
& \text { Www.imagesdetunisie.com }
\end{aligned}
$$
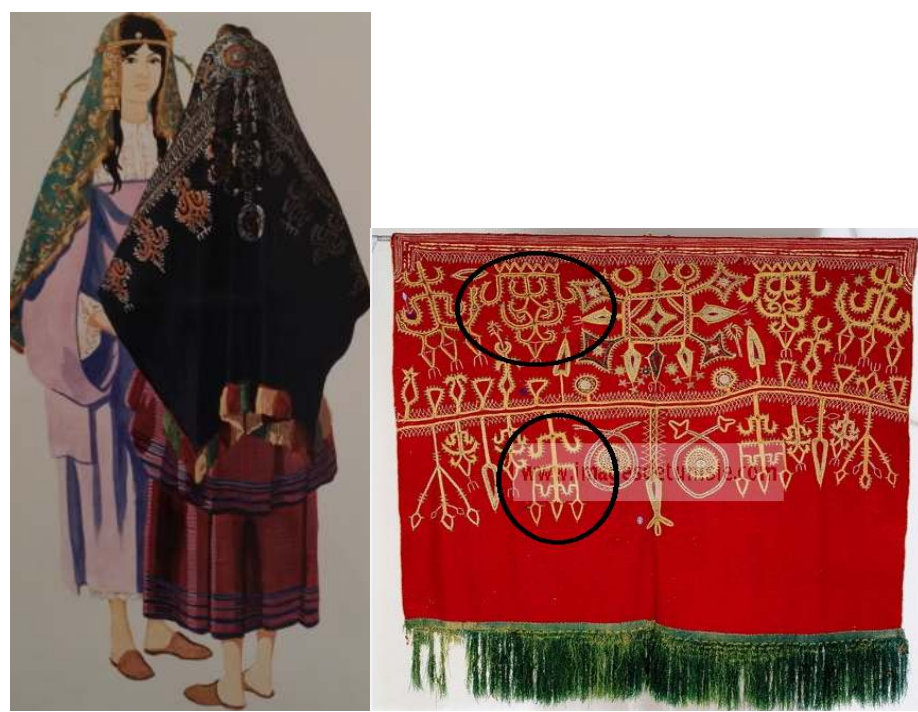

لوحة (r) شال القرن التاسـع عشر من الصوف الأسود

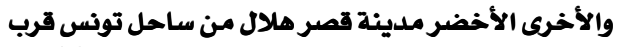

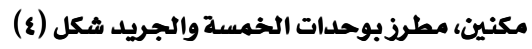
المصدر)(Aziza Ben Tanfous - 1978)

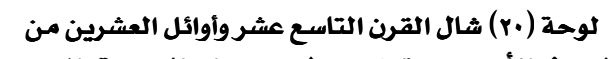

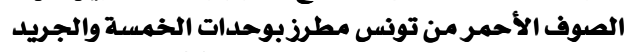

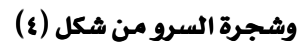

المصدر.wWw.imagesdetunisie.com 


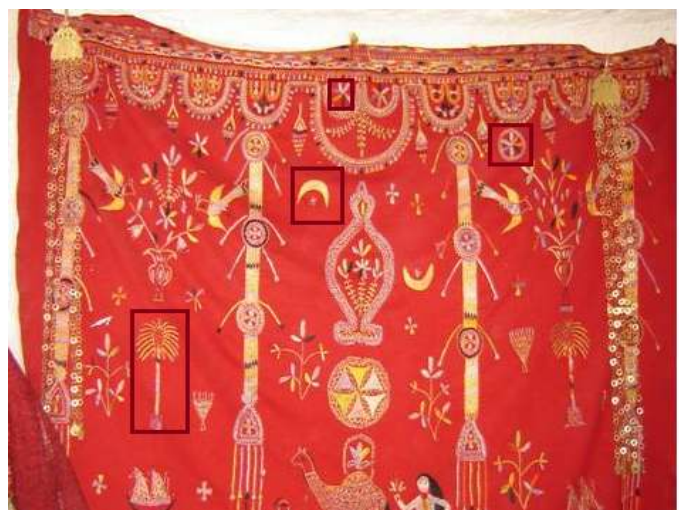

لوحة (rr) ثال (التعجيرة الحمراء) القرن التاسع عشر من القطن الأحمر من المغرب مطرذ بوحدات الخمسة والجريد

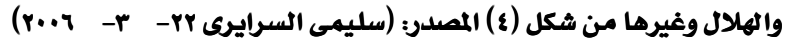

بالنسبة للتساؤل الثانى والذى نه على: ما الأثر الجمالى للعناصـر الزخرفيـة للوشـم أو

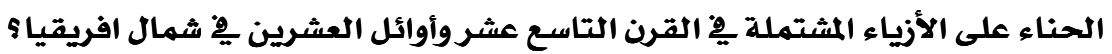

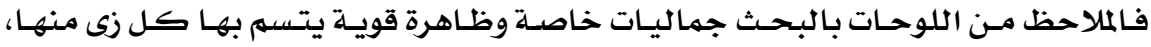
فرغم بسـاطة الزخرفـة وعناصـرها الرهزيـة وتهثيلـها سـواء بـالتطريز أو النسـج ،إلا أن الأثر الجمـالى

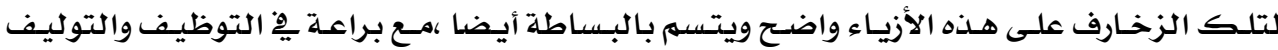
والتكرار للوحدات الزخرفيـة ،والألوان وتناسقها بـين أرضسية وخـامـة الزى وبـين العناصـر الزخرفيـة فيـه كها أن عدد الرموزوترتيبها على الزىى يحقـق الجـانب الجهـالى إلى جـانب الانتهـاء للقبيلـة مـا يهثل شـارات متعـارف عليهـا ومـا لـذلك كلـه مـن أثر جمـالى يقـترن بـالبعـد الاجتمهاعى ،ويكتمـل الأثـر الجمالى بالبعد التأصيلى يخ تهثيل تلك الزخارف لما لها مـن أبعـاد سـيكولوجية، وتاريخيـة ،وعقائديـة

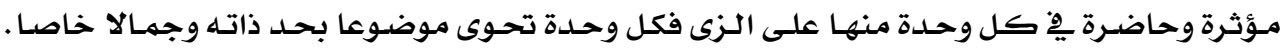

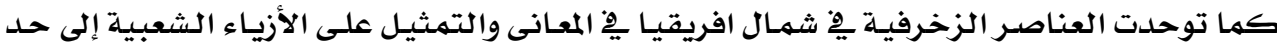
بعيد بـين طرفى السـاحل الأفريقى الشهـالى ،مـع الاختـلاف طبقـا للبيئـة التى عـاث أو نشأ فيها مـن دولة إلى أخرى ،ومـن مدينـة إلى أخـرى حسب العـادات والتقاليــ ،إلا أن الجميـع يـرتبط بوحسدة الأصل

$$
\text { البربرى الأمازيغى. }
$$

بالنسبة للتساؤل الثالث والذى نص على: ما الإمكانـات التصميمية لنمـاذج تاريخيـة مـن

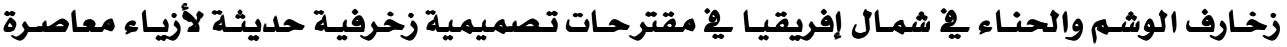

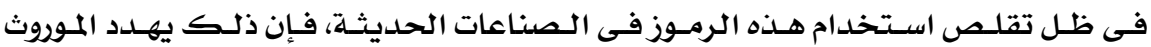
الـشعبى والخـصوصيـة الثقافيـة لتلـك المنـاطق والـذى هـو جـزء مـن هويـة الـشعوب العربيـة (محمـــ

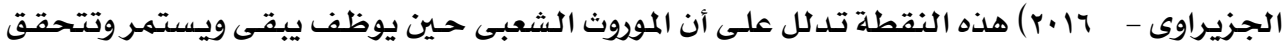

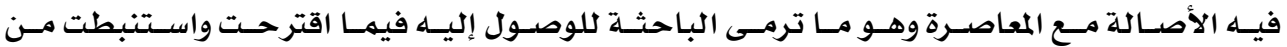

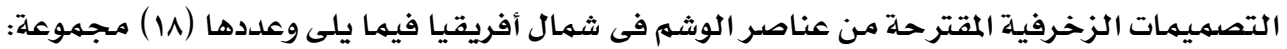




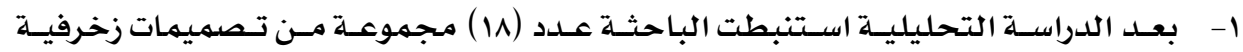

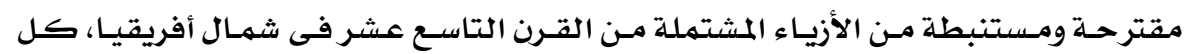

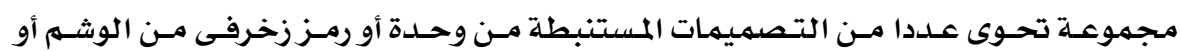

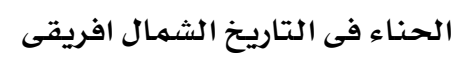

r- - استخدمت الباحثة برنامـج الرسام على الحاسب الآلى للحصول على التنوعات المختلفة .

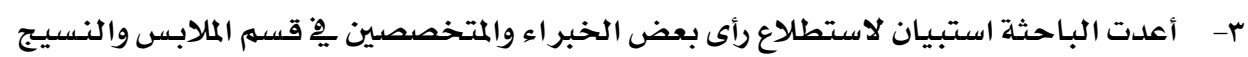

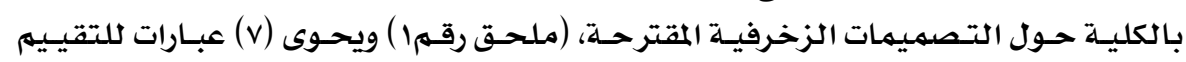

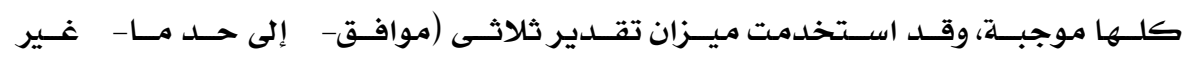

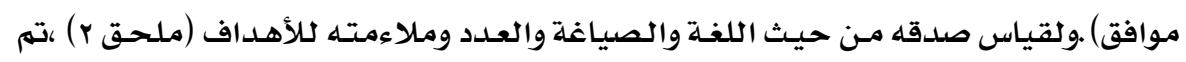

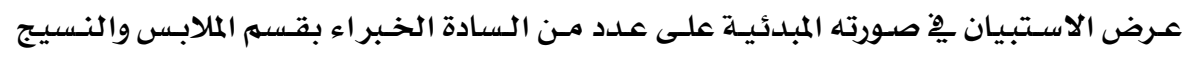

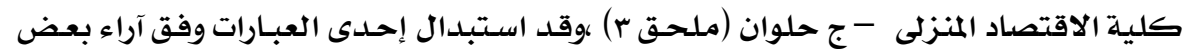
المحكمـين .

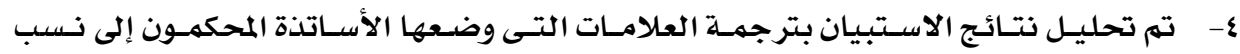

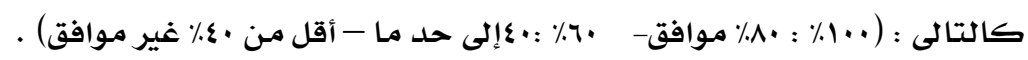
فيما يلى مجموعات التصميمات الزخرفية المقترحة: 

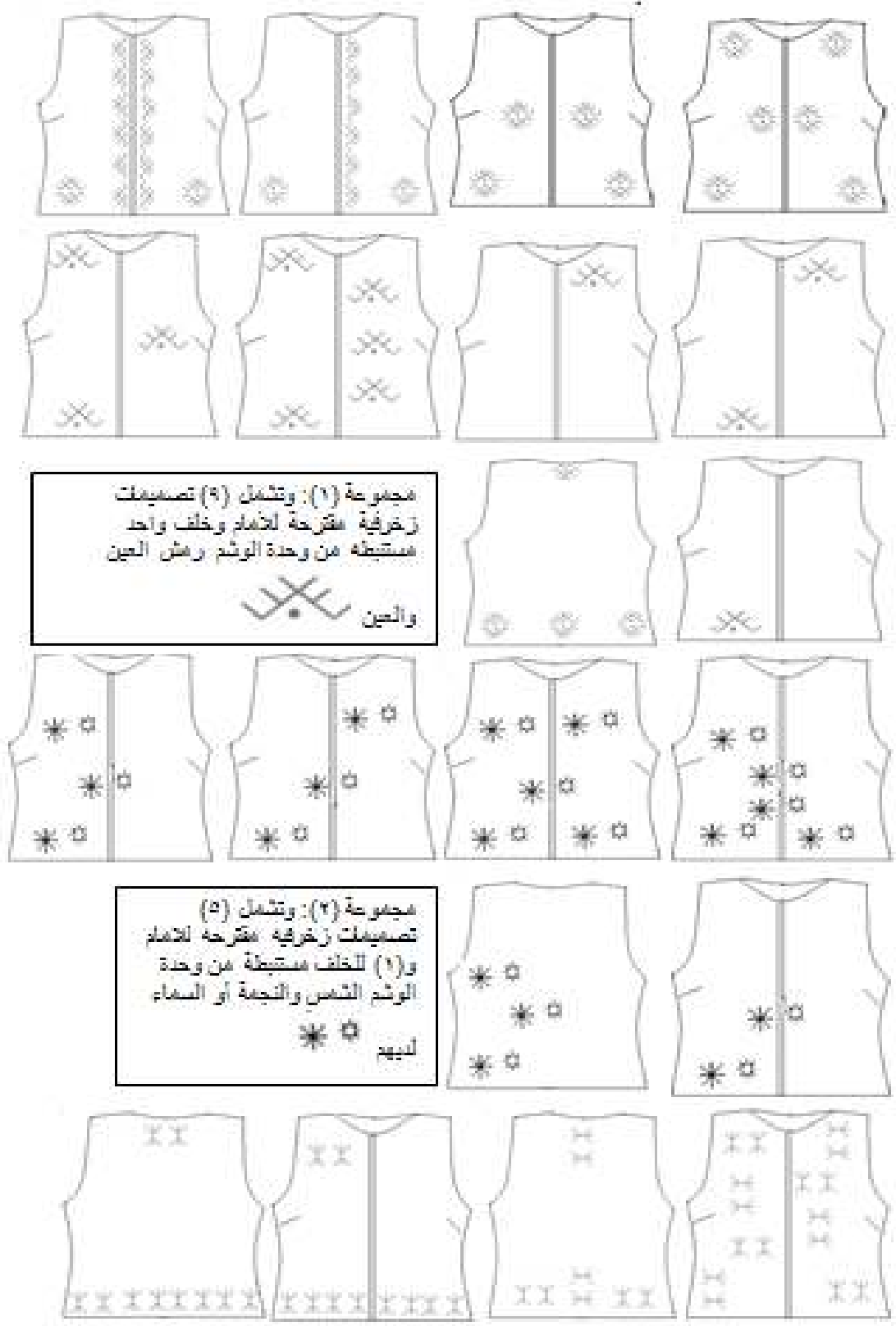

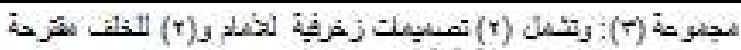

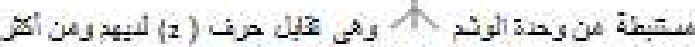




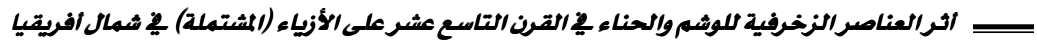
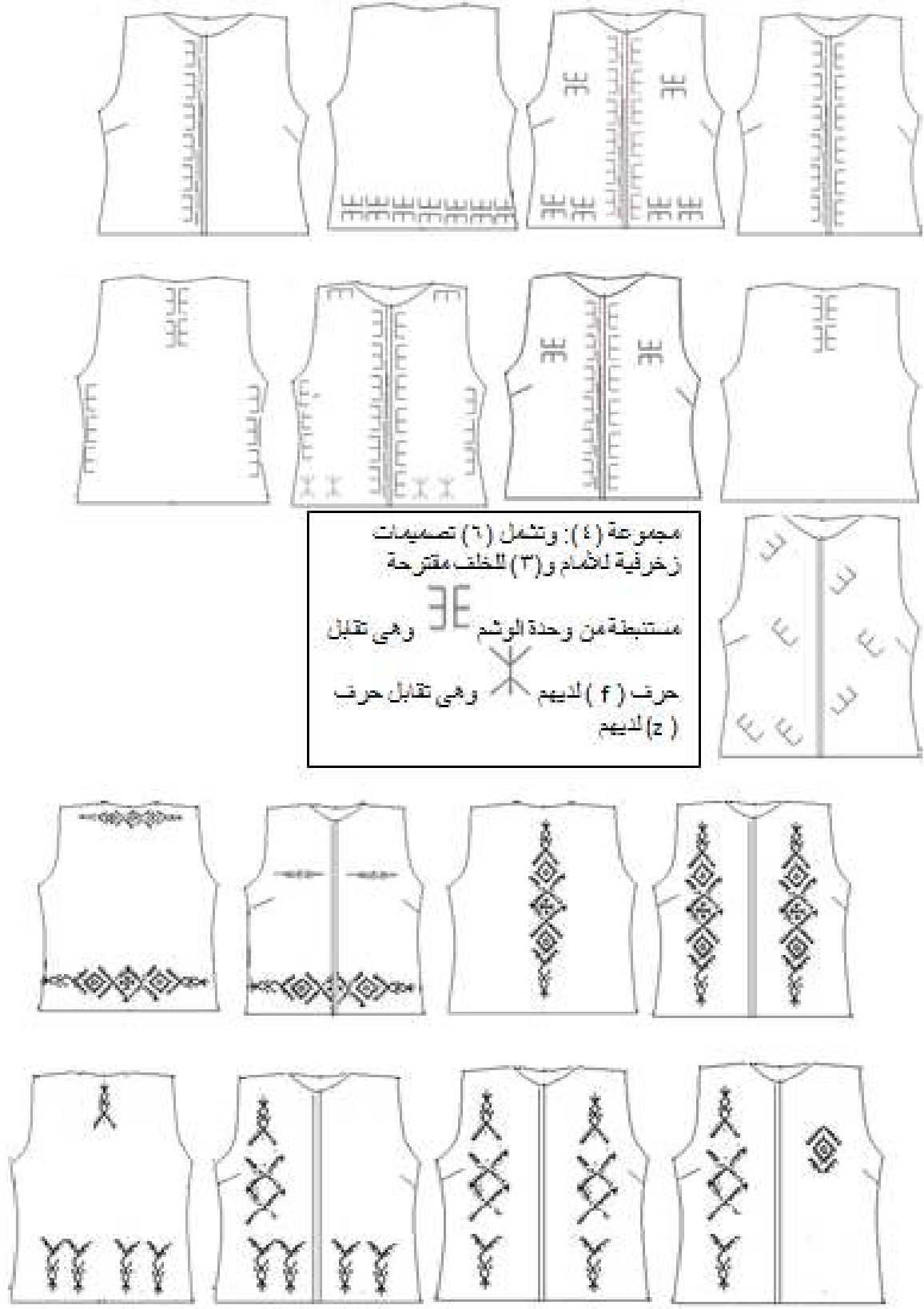

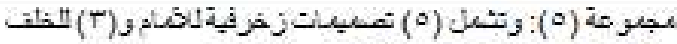

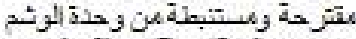

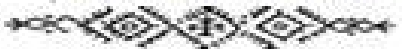



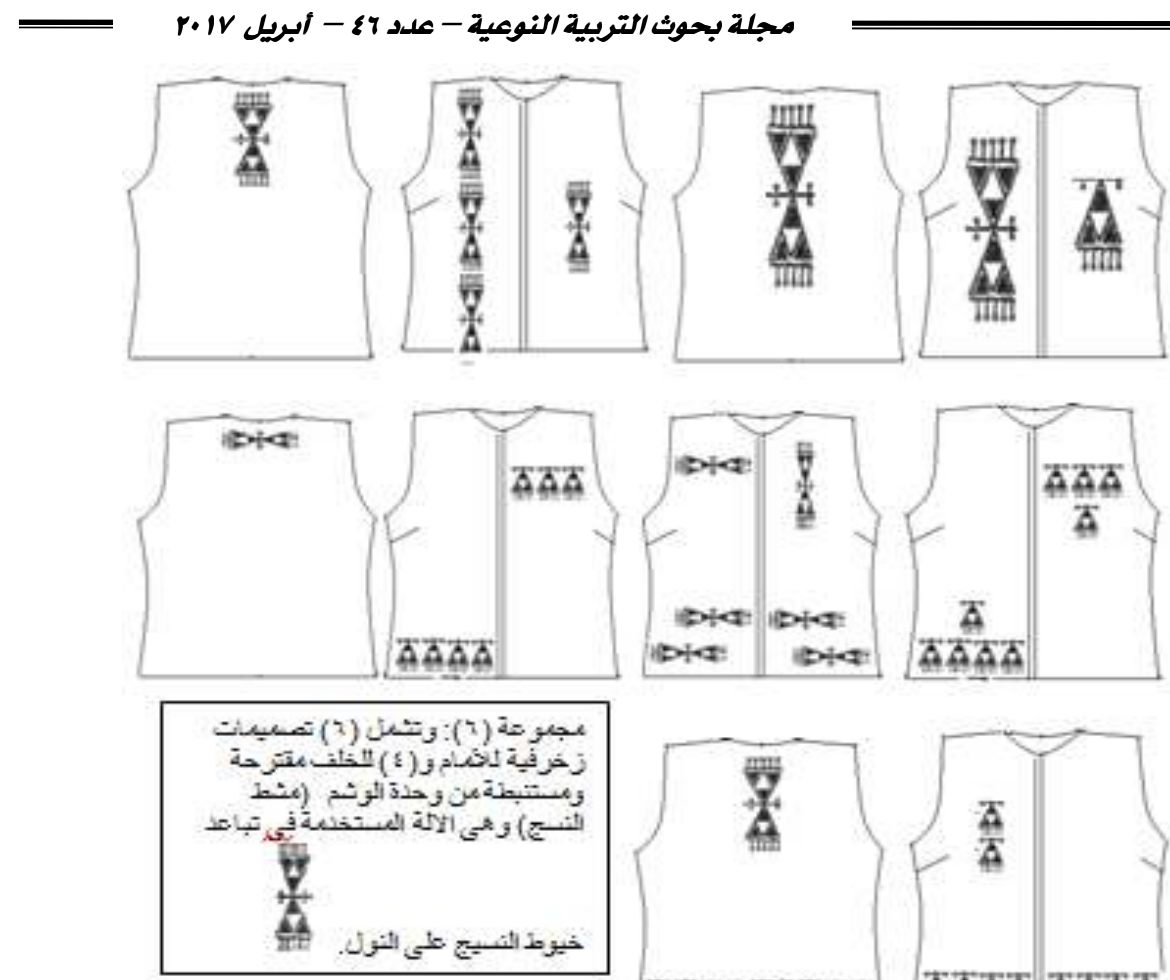

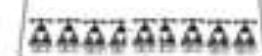

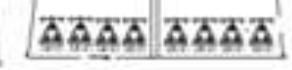
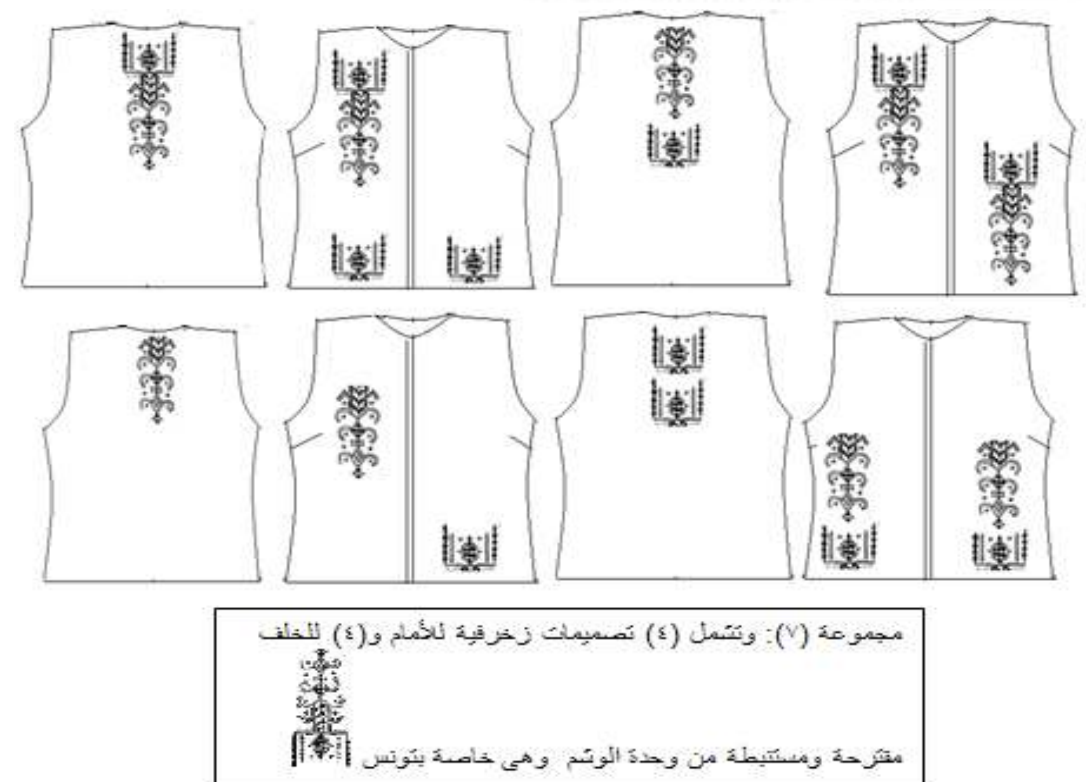

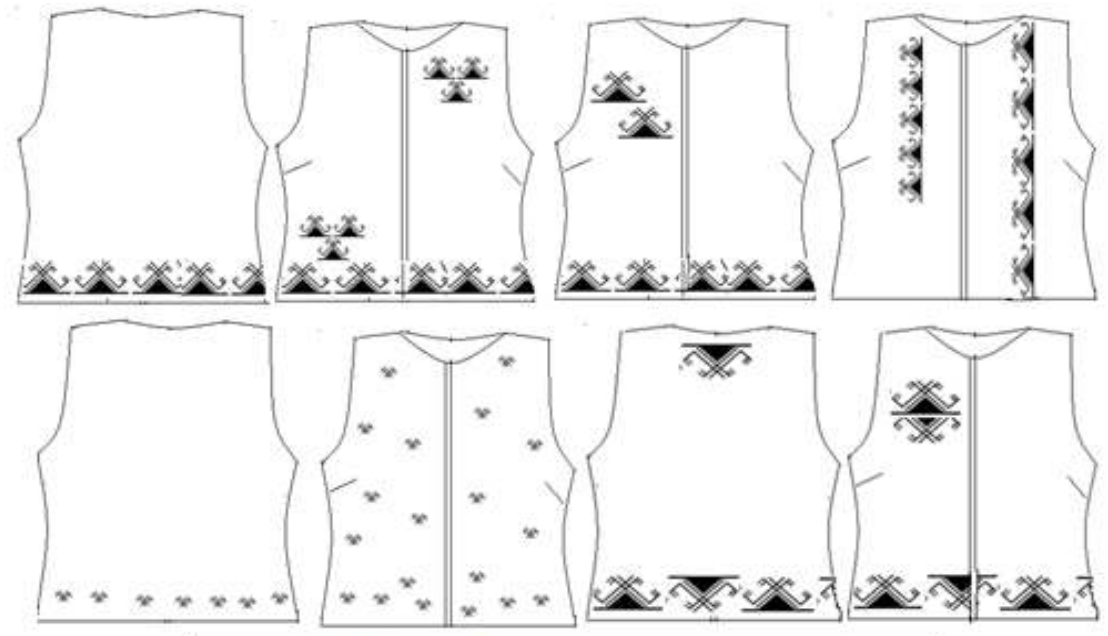

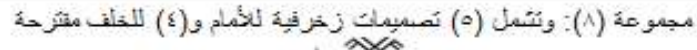

$$
\begin{aligned}
& \text { ومنسيطة من وحدَ الوتنم }
\end{aligned}
$$
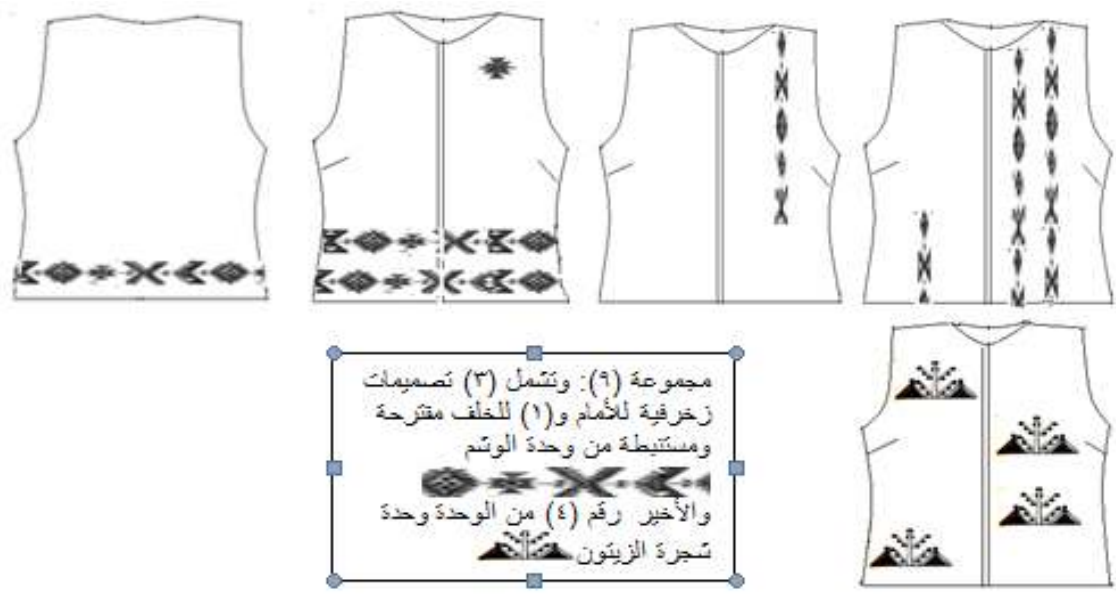
مجلة بحوث التربية النوعية - عدد r - أبريل r.lV
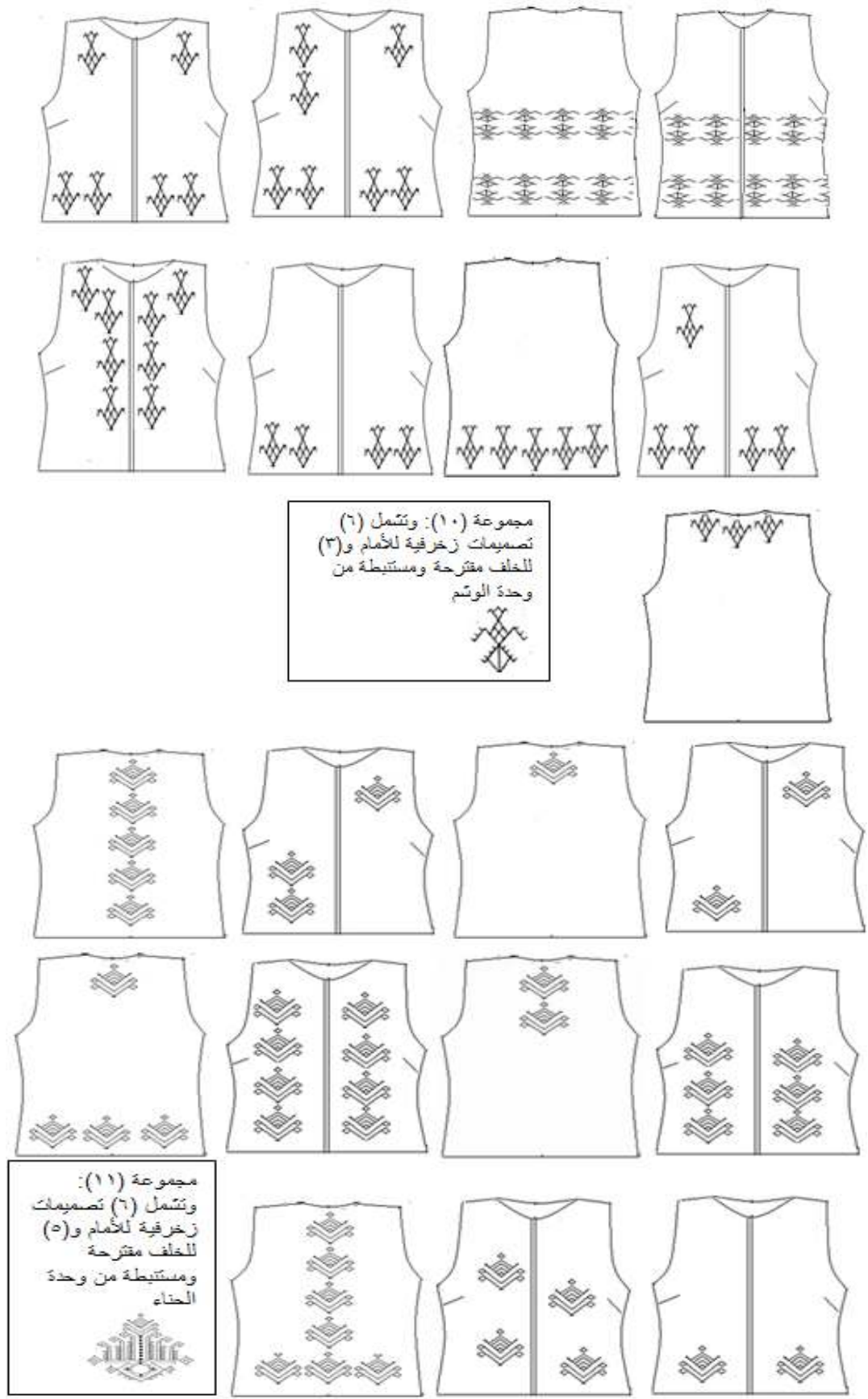


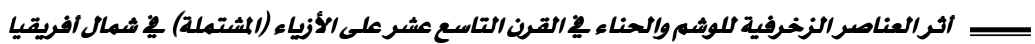
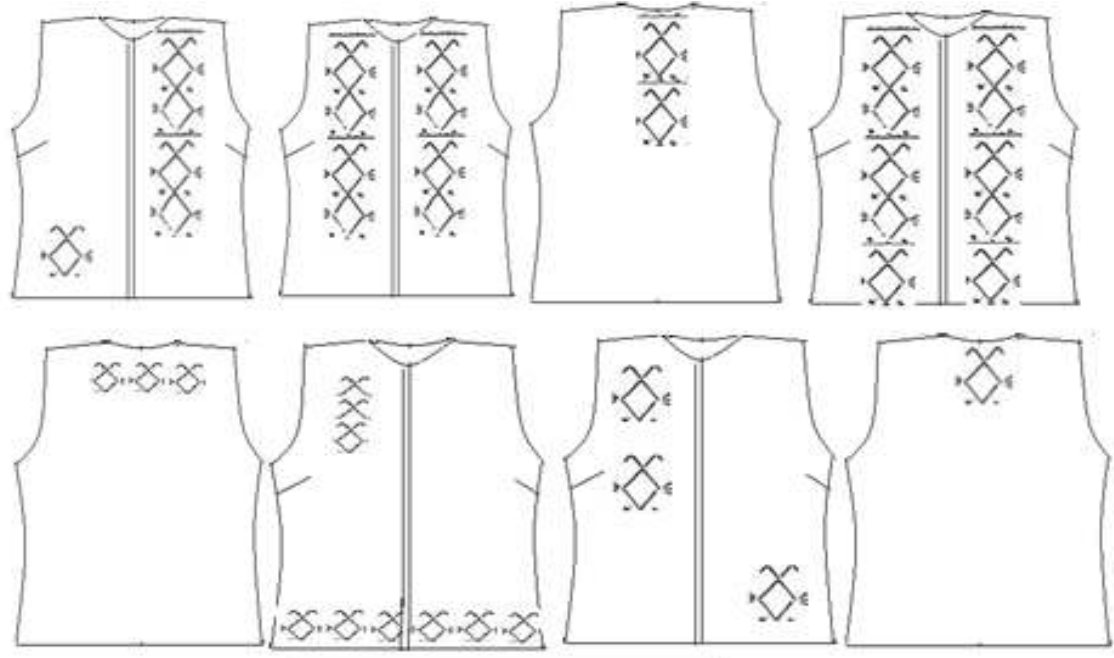

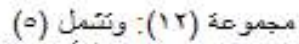
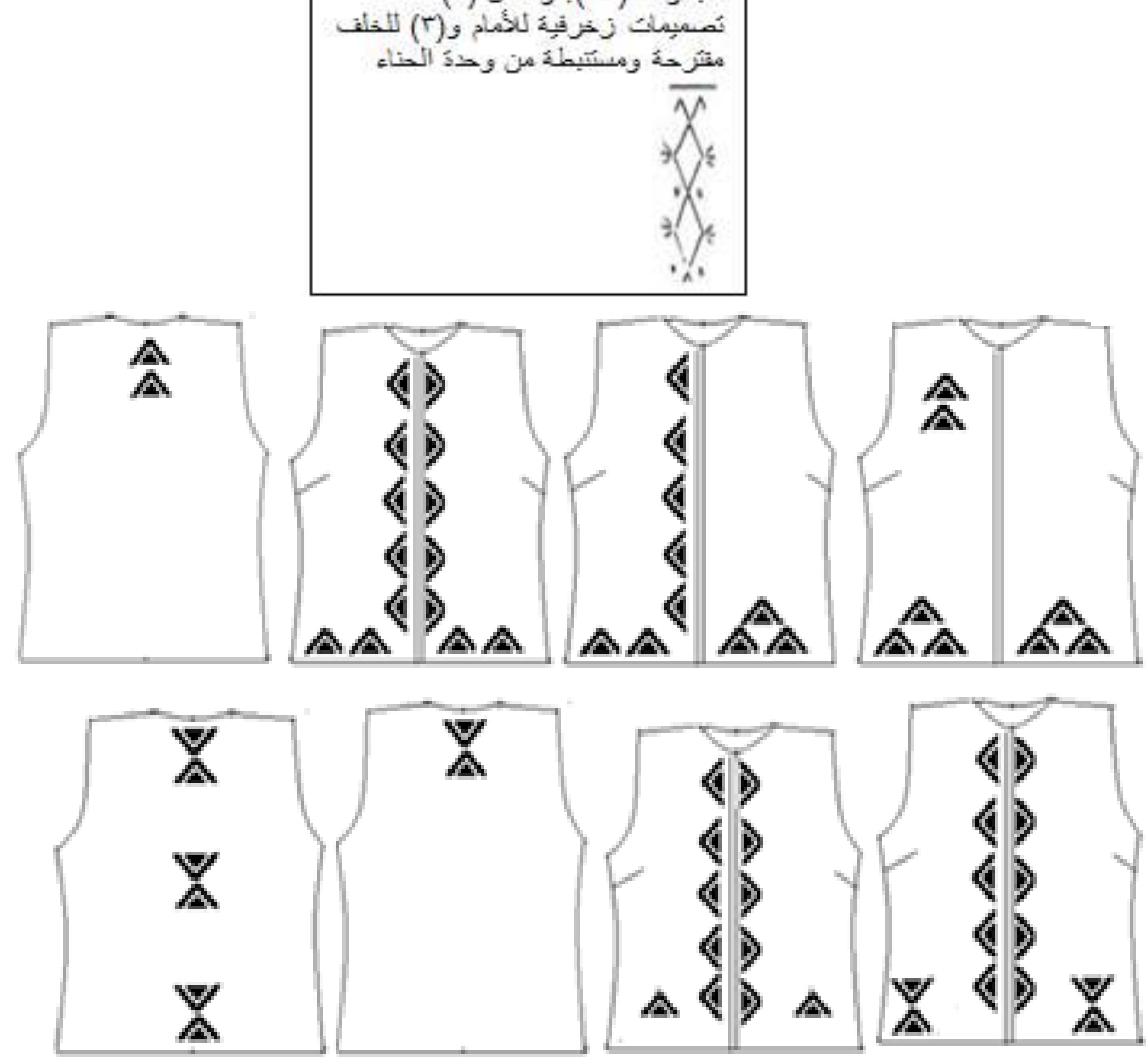

\section{rv.}


مجلة بحوث التربية النوعية - عدد r - أبريل r.lV
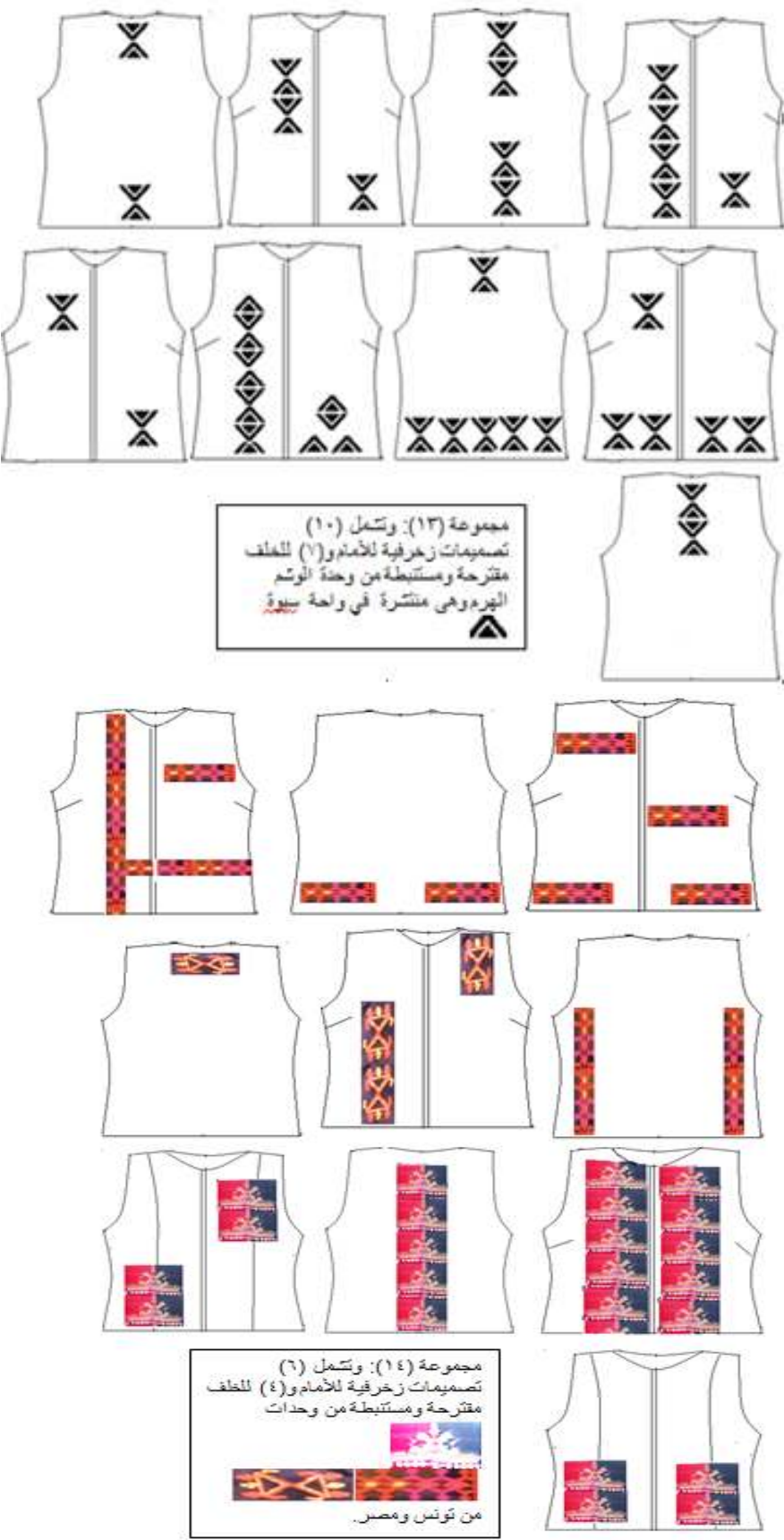

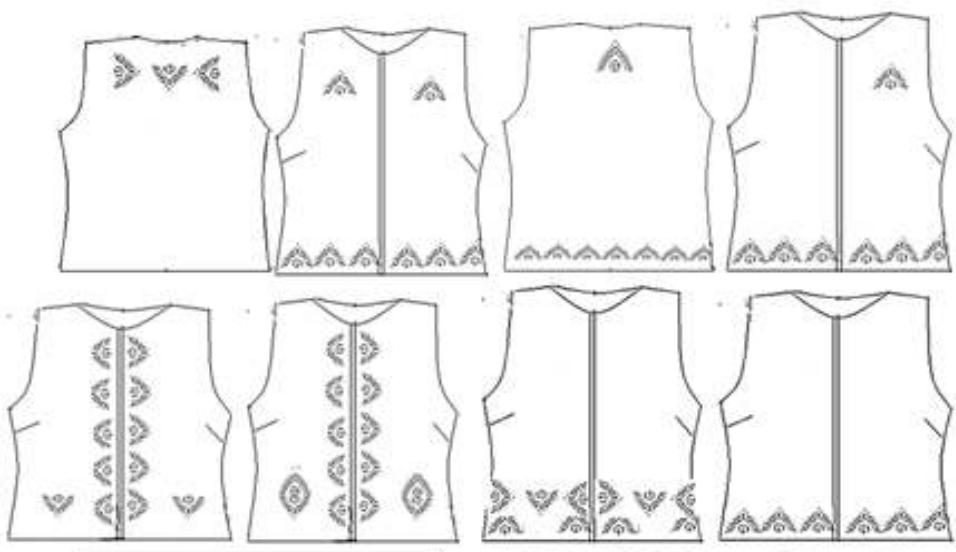

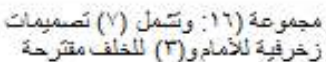

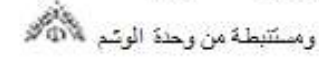
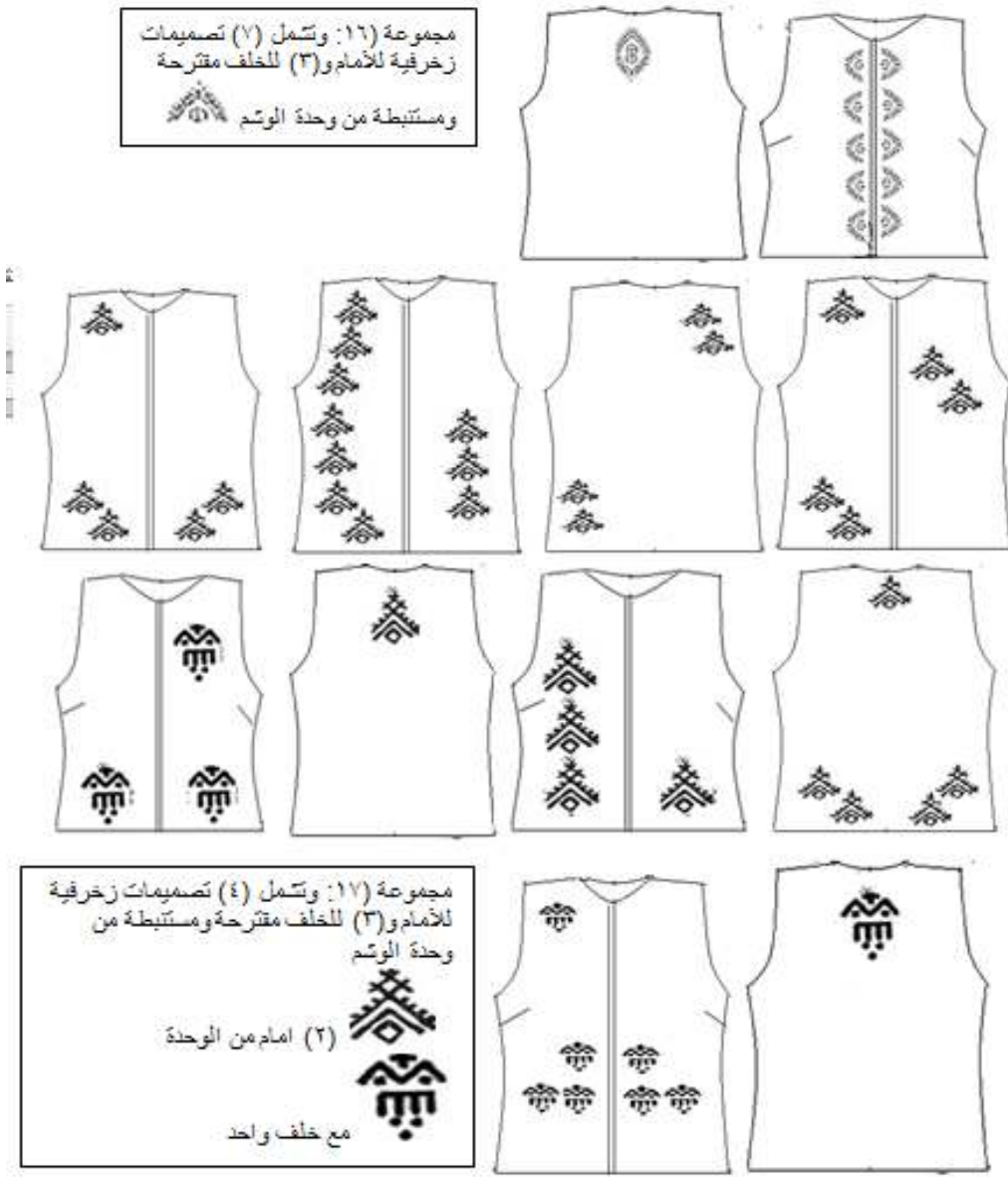


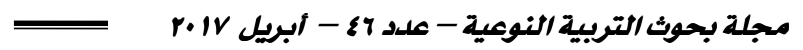
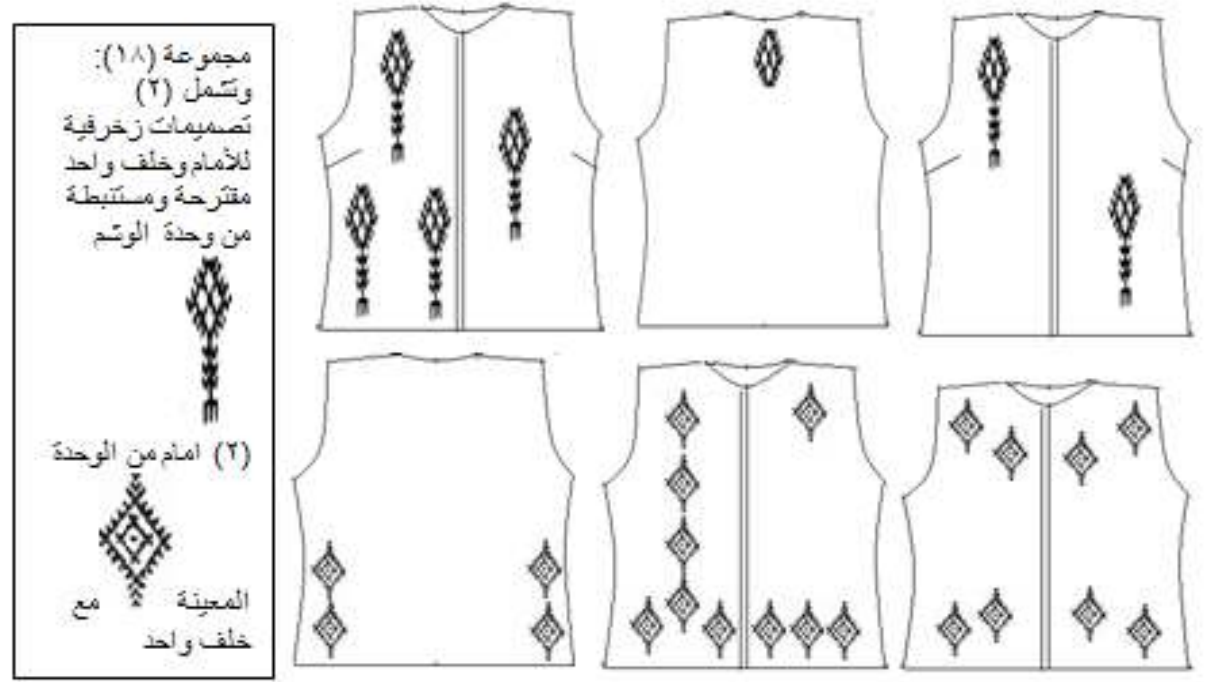

وتقترح الباحثة استخدام غرز السلسلة مـع الخيوط الصوفية أو المولونيـه الملونـة يِّ تطريز

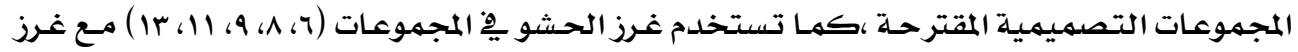

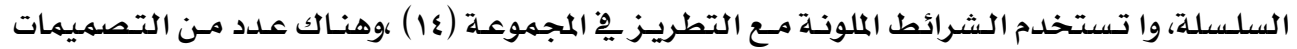

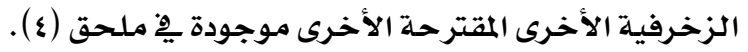

نتائج البمث وتمليل الاستبيانات :

الجدول التالى : يوضتح النسب المئويـة لعبارات الاستبيان 


\begin{tabular}{|c|c|c|c|c|c|c|c|c|c|c|c|c|c|c|c|c|c|c|c|}
\hline \multirow{2}{*}{ تصميه فى أفضل } & \multicolumn{3}{|c|}{ الحـ تناسب المجموعة } & \multicolumn{3}{|c|}{ | زـ يصلح كل تصميم } & \multicolumn{3}{|c|}{ الاحتفاظبشكل العنصر المعاصرة مع التحق المجوعة } & \multicolumn{3}{|c|}{ 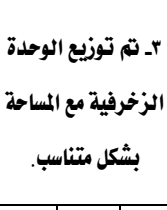 } & \multicolumn{3}{|c|}{ rـ تحققت الوحلدة بين } & \multicolumn{3}{|c|}{ الــ الزخرفية من الوشيف العناصر } & \multirow{2}{*}{ التقبيم } \\
\hline & |أوافق & أوافق & أوافق & أوافق & إوافق & أوافق & أوافق & أوافق & أوافق & أوافق & إلى حد & |أوافق & | أوافق & إوافق & أوافق & أوافق & إلى حد & | أوافق & \\
\hline ع بنسبة ..1\%٪ & - & - & $\% \cdots$ & - & - & $\%$ & - & - & $\%$ & - & - & $\% 1 \cdots$ & 一 & $\%$ & $\% \Lambda^{\circ}$ & - & $\%$ & $\% \wedge \cdot$ & 1 \\
\hline r بنسبة •l\% & - & - & $\% \cdots$ & - & - & $\% 1 \cdots$ & - & - & $\%$ & - & - & $\%$ & 二 & - & $\% 1 \cdots$ & - & - & $\% \cdots$ & $r$ \\
\hline | بنسبة ..1\%٪ & - & $\% r \cdot$ & $\%$. & - & $\%$ & $\% \Lambda^{\circ}$ & - & $\% r^{\prime}$ & $\%$. . & - & $\%$ & $\% \|^{*}$ & - & $\%$ & $\% \wedge$. & - & $\% r^{\prime}$ & $\% \Lambda^{\circ}$ & $r$ \\
\hline r بنسبة ..1\%٪ & - & - & $\%$ & - & - & $\%$ & - & - & $\% 1 \cdots$ & - & - & $\% 1 \cdots$ & - & - & $\% 1 \cdots$ & - & - & $\% \cdots$ & $\varepsilon$ \\
\hline r بنسبة •^^/ & - & - & $\%$ & - & - & $\%$ & - & - & $\%$ & - & - & $\% 1 \cdots$ & - & - & $\% 1 \cdots$ & - & - & $\% \cdots$ & 0 \\
\hline " بنسبة •ף٪٪ & - & - & $\%$ & - & - & $\%$ & - & - & $\%$ & - & - & $\%$ & - & - & $\% 1 .$. & - & - & $\% \cdots$ & 7 \\
\hline r بنسبة ..1\%٪ & - & $\% r$ & $\% \wedge$. & - & $\%$ & $\% \wedge$. & - & $\% r$ & $\%$. & - & $\% r^{\circ}$ & $\%$. & - & $\%$ & $\%$ • & - & $\%$ & $\% / \wedge \cdot$ & $\checkmark$ \\
\hline 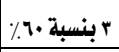 & - & $\% r^{\prime}$ & $\%$. & - & $\%$ & $\%$ • & - & $\%$ & $\%$ & - & 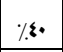 & $\%$ & - & $\%$ & $\% \wedge$. & - & $\%$ & $\% / \wedge \cdot$ & $\wedge$ \\
\hline |بنسبة •7٪ | & - & $\%$ & $\% \wedge$ • & - & $\%$ & $\% \wedge$. & - & $\%$ & $\% \wedge$ & - & $\%$ & $\%$ & 一 & $\%$ & $\% \wedge$ & - & $\% / \%$ & $\%$ & 9 \\
\hline ابنسبة •§٪/ & - & - & $\%$ & - & - & $\%$ & - & - & $\%$ & - & - & $\%$ & - & - & $\% 1 .$. & - & - & $\% \cdots$ & 1. \\
\hline r بنسبة •\&ء٪ & - & - & $\%$ & - & - & $\%$ & - & - & $\%$ & - & $\%$ r. & $\%$. & - & - & $\% 1 \cdots$ & - & $\%$ & $\% / \Lambda^{\circ}$ & 11 \\
\hline 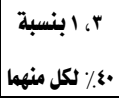 & - & - & $\%$ & - & - & $\% \cdots$ & - & - & $\%$ & - & - & $\% 1 \cdots$ & - & - & $\% 1 \cdots$ & - & - & $\% \cdots$ & Ir \\
\hline لا تصميم & - & - & $\% \cdots$ & - & - & $\%$ & - & - & $\%$ & - & - & $\% 1 \cdots$ & - & - & $\% 1 \cdots$ & - & - & $\% \cdots$ & ir \\
\hline لا تصميم & - & - & $\%$ & - & - & $\%$ & - & - & $\% 1 \cdots$ & - & $\% r^{*}$ & $\%$. & 二 & - & $\% 1 \cdots$ & - & $\% *$ & $\% \Lambda^{\circ}$ & $1 \varepsilon$ \\
\hline | بنسبة ..1٪٪ & - & $\%$ & $\% \Lambda^{\circ}$ & - & $\%$ & $\% \Lambda^{\circ}$ & - & $\%$ & $\%$. & - & $\%$ & $\%$. & - & $\%$ & $\%$ • & - & 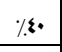 & $\%$ & 10 \\
\hline لا تصميه & - & $\%$ & $\%$. & - & $\%$ & $\%$ • & - & $\% r$ & $\%$. & - & $\%$ r. & $\%$ • & 二 & $\%$ & $\%$ • & - & $\%$ & $\% / \wedge^{\circ}$ & 17 \\
\hline لا تصميم & - & - & $\%$ & - & - & $\%$ & - & - & $\%$ & - & - & $\%$ & - & - & $\% 1 \cdots$ & - & - & $\% \cdots$ & iv \\
\hline | بنسبة •٪٪٪ & - & $\% r$. & $\% \wedge$. & - & $\%$ & $\% \Lambda^{\circ}$ & - & $\% r$. & $\% \wedge$. & - & $\% r \cdot$ & $\%$ & - & $\%$ & $\% \Lambda^{\circ}$ & - & $\% r \cdot$ & $\%$ & 11 \\
\hline
\end{tabular}




\section{تفسير النتائج}

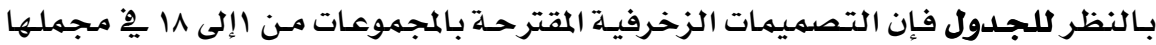

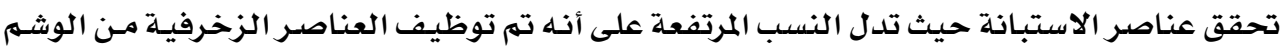

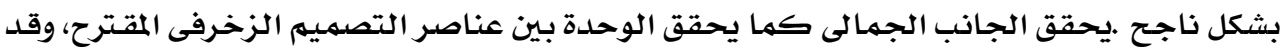

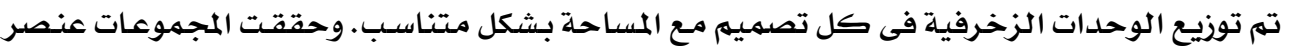

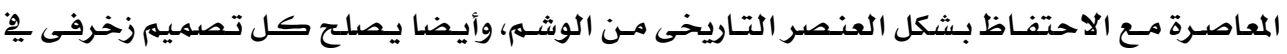
المجموعات المقترحسة لتنفيذه وتطريزه. كمها تناسب المجمهوعة المقترحسة المشروعات متتـاهيـة الصغر.

$$
\text { بما يحقق أهداف البحث . }
$$

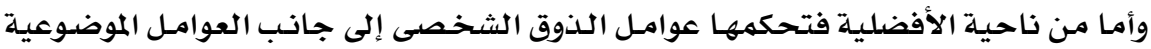

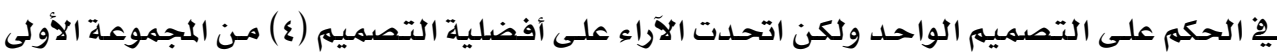

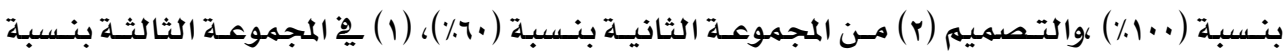

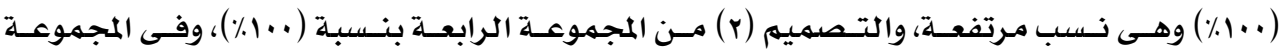

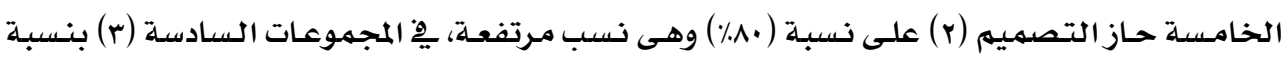

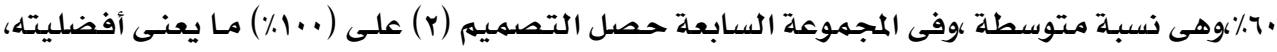

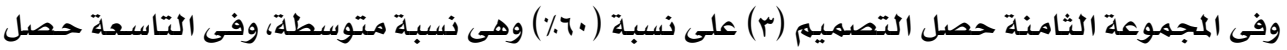

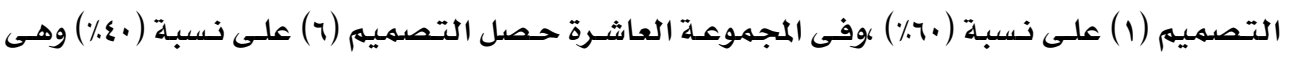

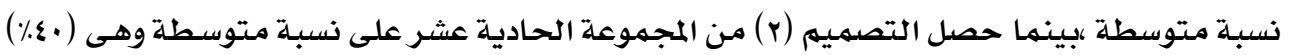

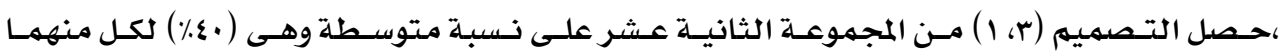

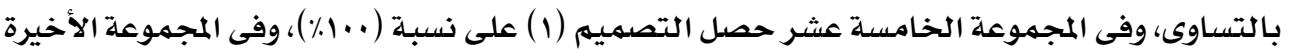

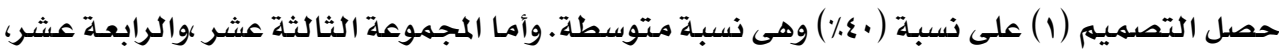

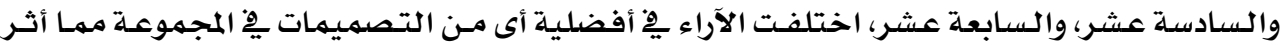

$$
\text { على نسب كل منها. }
$$

\section{الاستنتتاج العام:}

غالب الرموز على الأزياء المشتملة هى حروف من الكتابة الأمازيغية ،وأخرى أشكالا هندسية

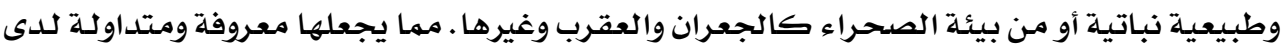

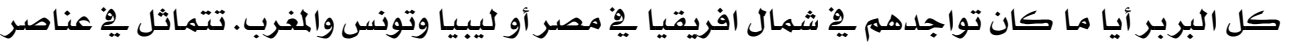

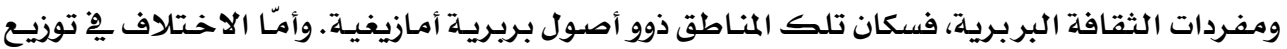

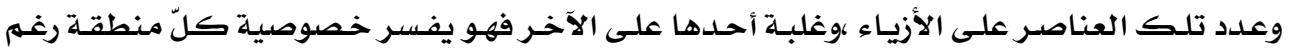
القرابة الجغرافية والثقافية. 


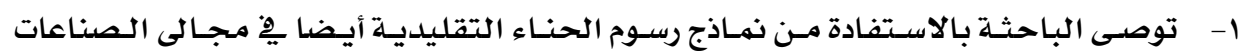

الجلدية والمكملات.

r- هناك إمكانية لتوظيف آخر وعناصر أخرى من الرموز المتعلقة بالوشمى والحناء بشكل معاصر

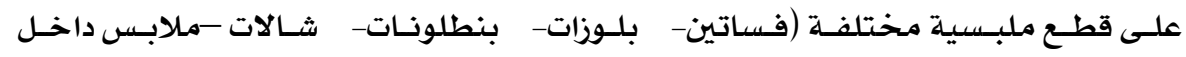

المنزل.إإخ)

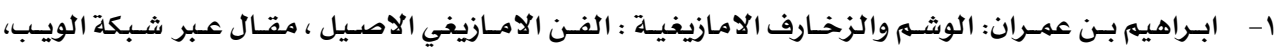

أحسن

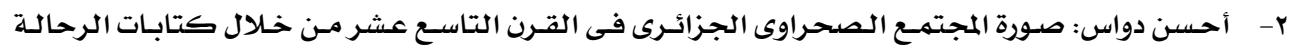

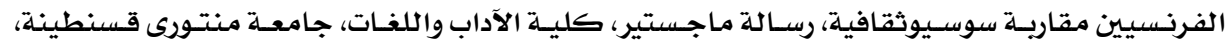

الجزائر، V... r الفرين

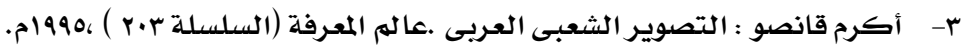

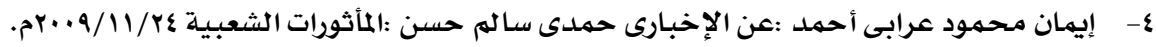

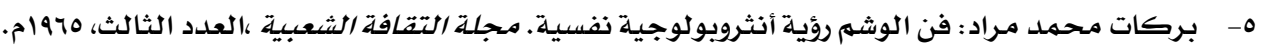

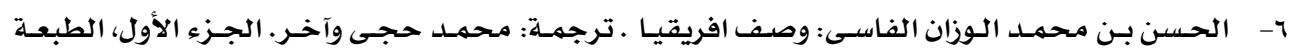

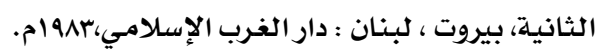

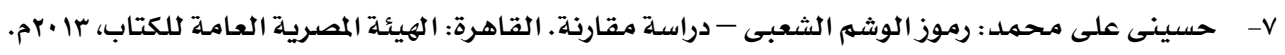

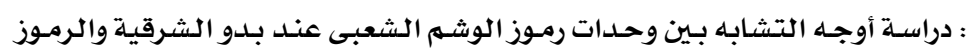

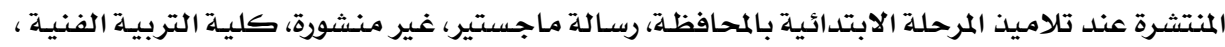

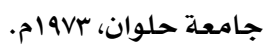

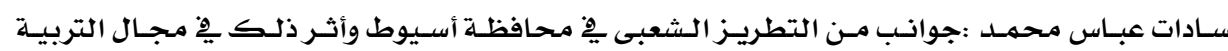

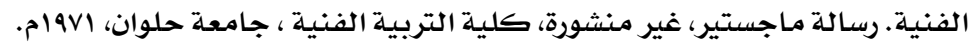

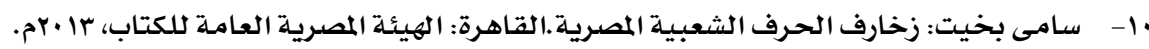

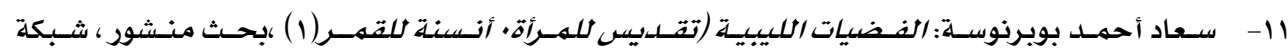

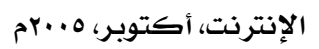

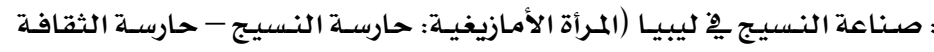
$-1 \mathrm{r}$

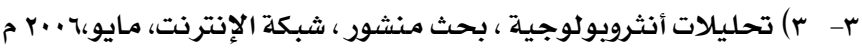

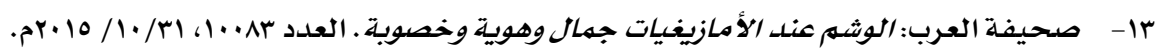

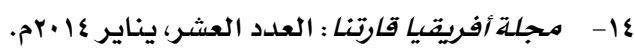

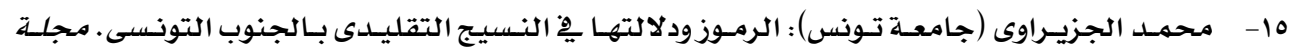

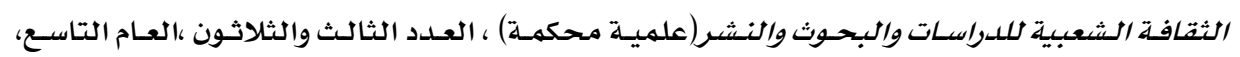

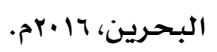




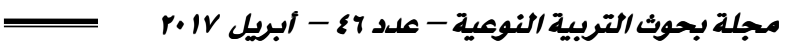

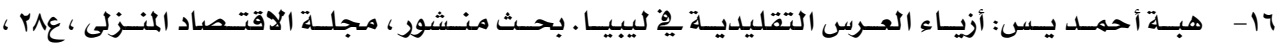

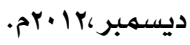

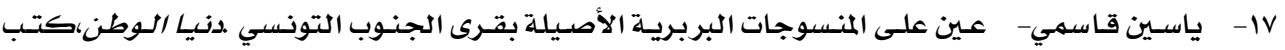

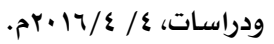

18 - AMEL TAFSOUT: The Culture and Arts of Morocco and the Berbers 01.10 .2003

19 - Aziza Ben Tanfous: Les costumes traditionnels féminins de Tunisie: ouvrage collectif publié par le Centre des arts et traditions populaires, Tunis, 1978.

20 - Catherine Cartwright-Jones: Encyclopedia of Hena North African Henna: History and Technique, Tap Dancing Lizard LLC,2008.

21 - — : The Henna Page "How To" North African Henna: Patterns Tap Dancing Lizard LLC,2008.

22 - — Elements, Tap Dancing Lizard LLC,2008.

23 - Cyrthfa I.becker: Amazigh Arts in Morocco: The culture and Arts of Morocco\& the berbers, Magazine

24 - Gabrel Rousseau :Le Costume Au Maroc ,E .De Boccard ,Paris,1938.

25- Jean Besancenot: Costumes of Morocco , Kegan baul International, London \& New York, 1990

26 - Harquus: Encyclopedia of Hena: North African Women's Traditional Body Art Volume 2, Volume 4: Paint Tap Dancing Lizard LLC, 2009.

27- Urban Textiles and costumes: https://africa.si.edu/exhibits/fabric/education.html

- www.encyclopedieberber.com

- www.imagesdetunisie.com

- http://lastora.com/vb/showthread.php?t=2819

- http://www.nouhworld.com/article.html

- www.pinterest.com-

- http://www.sasapost.com/amazigh-in-north-afrique-

مؤسسة ثقافية أمازيغية

-www.wikipidia.com- 


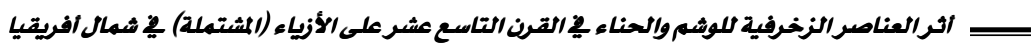

The Impact Of The Ornamented Elements, Henna \& Tattoo On The (Inclusions)

Costumes In North Africa At The Nineteenth Century

\section{Abstract}

This Research aims to study some Historical Styles for ornamentations henna and tattoos in the nineteenth and early twentieth century, on the inclusions costumes, at North Africa ,and its impact aesthetic them. also preparation of Ornamented designs proposed characterized by modern and contemporary derived from a historical styles for Ornamentations henna tattoos, suitable for embroidery on clothes to achieve the aesthetic aspect of it. The contemporary approach to folklore in various aspects is problematic in itself, To practically applied it, needs to a deep understanding of the study and assimilation of its components and its components with a new additions, sense of The Artist, and therefore, this approach differs from An Artist to another, or from A person to another. After the analytical study, The Researcher devised (18) A set of Ornamented designs groups proposed and developed out of costumes inclusions of the nineteenth century in North Africa, each group containing a number of designs derived from the a motif, or an Ornament tattoos or henna symbol, in the history of North African, used a Paint program of computer to do different variations . Researcher makes questionnaire to poll some experts and specialists in the clothing and textile department faculty about the proposed Ornamented designs, (Appendix 1). It has (7) statements to evaluate all are positive, it has used the balance of trilateral estimate (agree - To some extent - not agree). After measuring its sincerity it has been analyzing the results of the questionnaire translated Brands developed by professors arbitrators to ratios as follows: (100\%: $80 \%$ agree - 60\%: 40 to some extent - less than $40 \%$ not agree), the most important results, was Achieving the objectives of the proposed designs questionnaire, and therefore the Aims of the Research, The results found that the degree of representation of decorative tattoo or henna on inclusions costumes in the nineteenth, and the early twentieth century, in North Africa, large due to the firmness of those symbols, combined with the customs and traditions inherited in this regard has increased, including the extermination of the Islamic religion usually tattoo turned those symbols to ornament traditional costumes own Berbr North Africa, also enjoyed beside its Beauty is very large, has been possible to develop designs which are derived the contemporary as previously noted,

The Recommendations was try to take advantage of the traditional henna fee styles are also in the fields of leather industry, accessories

- There is a possibility to employ another and other elements of symbols related to tattooing and henna in a contemporary cut different clothes (Dresses Blouse trousers - shawls, indoor clothes..etc). 